\title{
An International for the Global Radical Waterfront
}

The 'International Conference of Seamen and Harbour Workers' was scheduled to start on 1 October 1930. As the delegates were expected to arrive at Hamburg a few days earlier, Albert Walter's plan was to organise a mass rally and had hired a spacious hall for the event. However, only the British, Dutch, German and Scandinavian delegations had arrived at the end of September. Other participants were delayed and the start of the conference had to be postponed until 3 October $193{ }^{\circ} .^{1}$

Typically for communist conferences, a full list of participants was never published. According to an internal memorandum, 38 delegates from 26 countries attended the conference although few of them had been nominated by their national trade union opposition groups to represent them at the conference. ${ }^{2}$ Others, especially those claiming to represent opposition groups in 'semi-colonial' and colonial countries, seems to have been handpicked among mariners residing in Hamburg. ${ }^{3}$ A pamphlet published shortly after the conference listed delegates originating from 24 countries and territories, including Algiers, "Arabia," Argentina, Belgium, Brazil, Britain, Canada, Chile, Finland, France, Germany, Greece, India, Indonesia, Italy, Japan, Korea, the Netherlands, Norway, Paraguay, the Soviet Union, Sweden, Uruguay, and the USA. The idea of the pamphlet was propagandistic: Its objective was to tell its reader about the establishment of a new radical global organisation for rallying seamen and dockworkers under its - existing or planned - national sections in all of the aforementioned countries. Most importantly, however, was the denunciation of the ITF, depicting it as the traitor of the working class as well as being a lackey of the shipowners and of the aggressors towards the Soviet Union. ${ }^{4}$

1 Y [Walter,] Sonderbericht zu der internationalen Konferenz der Seeleute und Hafenarbeiter am 3. Okt[ober] 1930 in Hamburg, 534/5/219, 22-24, RGASPI.

2 ISH, Half-Year Report October 1930 - April 1931, 534/5/221, 68, RGASPI. According to the report, the delegates arrived from Argentina, Algiers, Belgium, Brazil, Canada, Chile, China, England, Finland, France, Germany, Greece, India, Italy, Japan, Korea, the Netherlands, Norway, Paraguay, Peru, the Philippines, Poland, Sweden, Uruguay, the USA and the UssR.

3 Handwritten report about the meeting of 3 rd October 1930 (in German), 534/5/219, 21, RGASPI.

4 Declaration to seafarers and harbour workers in German, no date [ca. October 1930], 534/5/ 219, 12-16, RGASPI. The declaration was published as supplement titled "An alle Seeleute und Hafenarbeiter! To all seamen and harbour workers! Proletarier aus den Häfen und von den Schiffen!," in Hamburger Volkszeitung, Beilage zu Nr 233, 7.10.1933. 
The conference started by electing a presidium, consisting of Albert Walter as chair and George Mink as secretary as well as Fred Thompson, a "Negro delegate, ${ }^{5}$ and George Hardy as members. ${ }^{6}$ Next, Hardy presented a lengthy report on the impact of the global depression on world economic and political affairs and the need to establish an International for the maritime transport workers. The ITF and the Amsterdam International, i.e., the International Federation of Trade Unions or IFTU, had betrayed the proletariat, Hardy declared, and further criticised them for supporting the 'imperialists' in their onslaught on the working masses in the colonies, not least in China and India. The key objective for the new International was therefore to render full support to the fight for national self-determination and independence of the colonial and semi-colonial countries. After Hardy's one and half hour speech, comrade Ray ${ }^{7}$ from the USA took the floor and read out a petition signed by the US American, British, Chinese, French and German delegations, calling for the establishment of an International for maritime transport workers. Storming applause: The petition was unanimously accepted and the International of Seamen and Harbour Workers or IsH had officially been launched. The Italian delegate asked for a condemnation of fascism to be included in the resolution text. Acclamations and accepted. Then the Chinese delegate stood up and presented a proposal by the Chinese, French, and Scandinavian delegation for the statutes of the new International. Storming applause: The statutes were accepted. ${ }^{8}$ So far, the conference gave the impression of expressing the unanimous and resolute will of the global revolutionary maritime transport workers. No hints about the conference having been prepared in Moscow or articulating a plan outlined by the RILU and the IPAC-TW. Instead, it was presented in public as having been initiated at the national conference of the Marine Workers' Industrial Union held in New York in April 1930.9 The conference

5 I have not been able to identify the "Negro delegate." It certainly was not James W. Ford as he resided in Moscow in October 1930, and together with George Padmore organised the RILU Negro Bureau.

6 “Til alle Søfolk og Havnearbejdere," Lanternen 5, no. 7 (Oktober 1930): 1. Conflicting information consists for the composition of the Presidium; according to a handwritten report, Walter was elected chair, Thompson and one Toussaint from the USA as secretaries while Mink, Hardy, Dumay and one 'Centurion' are instead as members, see Handwritten report about the meeting of 3 rd October 1930 (in German), 534/5/219, 21, RGASPI.

7 This was probably Tommy Ray, the organiser of the MWIU in San Diego.

8 Bericht über die internationale Konferenz der Seeleute und Hafenarbeiter am 3. Oktober 1930 in Hamburg, no date [ca. October 1930], 534/5/219, 2-5, RGASPI.

9 "Til alle Søfolk og Havnearbejdere," Lanternen 5, no. 7 (Oktober 1930): 1. 
ended with the adoption of a resolution, summarising the objectives of the new International and appealing to

all seamen and dockers to unite, to join the revolutionary class unions and minorities for the purpose of struggling to increase wages, the improvement of labour conditions, the shortening of the working day, for equal wages for equal work, for full economic, social and political equality of all transport workers irrespective of colour, creed, nationality or race, against capitalist rationalisation, and fully in a struggle for the overthrow of capitalism and the establishment of socialism. ${ }^{10}$

The communist press hailed the establishment of the ISH as a landmark for the radical maritime transport workers, see Figure 10. The new organisation was heralded as the bulwark against the shipowners, the fascists and the social democratic union leaders; ${ }^{11}$ an official declaration on its establishment was published in the Internationale Presse-Korrespondenz on 14 October. ${ }^{12}$ Internally, not all comrades acclaimed to the gloss image of a historic landmark. Leading members of the ISH Executive Committee critically commented the decision to shorten the conference into a one-day event, leaving no room for discussions or debates about the statutes and objectives of the new organisation. Walter, in an internal report to the IPACTW headquarters, replied that it would have been practically impossible to extend the conference, not least, as none of the participants had any financial means at their disposal to pay for their return. Consequently, he had to cover their expenses and the Port Bureau had run out of money at the end of the conference. ${ }^{13}$

10 Resolution adopted by the International Conference of Seamen and Dockers, held at Hamburg, October 3rd, in George Hardy, A Fighting International of Marine Workers (Hamburg: International of Seamen and Harbour Workers, 1930), 30.

11 "An alle Seeleute und Hafenarbeiter! To all seamen and harbour workers! Proletarier aus den Häfen und von den Schiffen!," Hamburger Volkszeitung, Beilage zu Nr 233, 7.10.1933; “Til alle Søfolk og Havnearbejdere," Lanternen 5, no. 7 (Oktober 1930): 1; "Kampinternational för sjöfolk bildad," Kalmardemokraten 8.10.1930.

12 Inprekorr 86/14.10.1930, copy checked in Reichsministerium des Inneren. Internationale Hafenbüros und Seemannsklubs, Jan. 1930-Nov. 1933, R1501/20224, BArchB.

13 [Walter,] Sonderbericht zu der internationalen Konferenz der Seeleute und Hafenarbeiter am 3. Okt[ober] 193 o in Hamburg, 534/5/219, 22-24, RGASPI. 


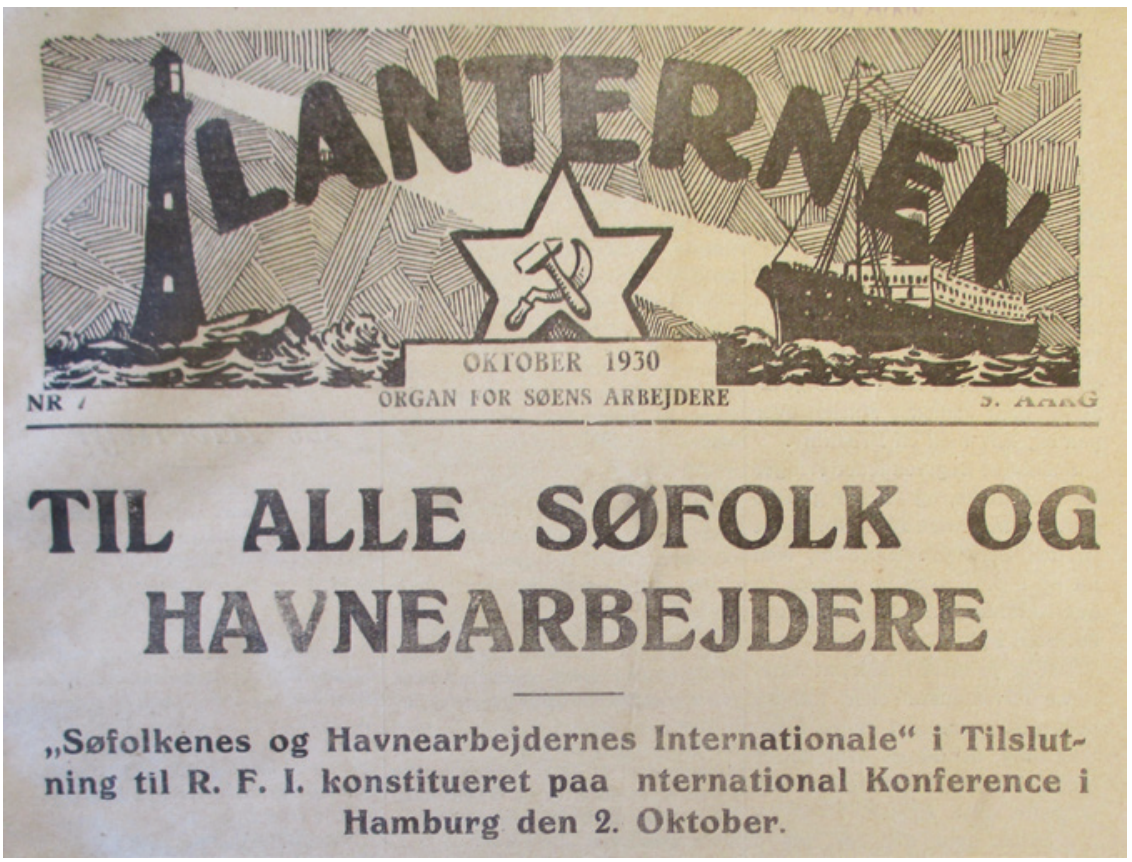

FIGURE 10 The International of Seamen and Harbour Workers has been launched!, first page news published in Lanternen 5, no. 7 (October 1930): 1. Workers

Moscow's grand strategy was to present the ISH as a revolutionary but independent organisation. Hamburg, not Moscow, was the seat of the new organisation; its statues were silent about the relationship between the RILU and the ISH. According to the statutes, the ISH Bureau and/or the IsH Executive Committee made all decisions and signed all declarations. In reality, all declarations and decisions had to be in tune with the instructions issued by the RILU Secretariat and had to be approved by the RILU Berlin Bureau. At first, this strategy seemed to have worked. The new unit was for several months an unwritten chapter for government authorities. A lengthy report by a German police informant even claimed that the IS $\mathrm{H}$ had been established at an international meeting of harbour workers and seamen held in Altona on 10/11 January $19311^{14} \mathrm{~A}$ critical evaluation of the situation soon corrected this assumption:The 14 Report 'Internationale Konferenz der R.G.O.' by C.3 and C.4 to Abteilung IA, dated Altona
12.1.1931, Abt. 301 Nr. 4532, LAS. 
ISH had already been established in October $1930 .{ }^{15}$ In fact, the January 1931 meeting concerned the formation of a German section of the ISH. ${ }^{16}$ On the other hand, the local police authorities did not change their position: No international activities had been reported before January 1931, thus they reasoned that the ISH became effective only after the meeting in January. ${ }^{17}$

\subsection{The (Provisional) Statutes of the ISH}

The most important decision of the October 1930 Hamburg Conference was the adoption of provisional statutes for the new organisation. These had been prepared in advance in Moscow as they were published by the German communist periodical Rote Fahne on 3 October 1930, claiming that the conference had summoned already on 2 October; ${ }^{18}$ in fact, the Political Commission of the ECCI had approved them at its meeting on 20 September. ${ }^{19}$ According to the provisional statutes, the official name of the new organisation was International of Seamen and Harbour Workers, abbreviated Is H. Echoing the wordings of the 'Basic Principles' (see Chapter 5.4.4), the objectives of the ISH were 1) to unite seamen, river transport workers and harbour workers in revolutionary opposition groups, minorities or red trade unions, 2) to organise and lead the fight of the maritime transport workers in their struggle for increased salaries, reduced working hours and the introduction of social insurances, and 3) to unite them in the fight against deteriorating working conditions and reductions in wages. Further, the ISH was to adhere to the 'United front from below'-tactic and invite organised as well as unorganised maritime workers to join in the struggle against the exploitations of the shipowners, the bourgeois governments, the 'social fascist' trade union leaders, the International Labour Office and the ITF. ${ }^{20}$

15 Letter from 'Preussische Minister des Inneren an den Oberpräsidenten in Kiel', Berlin 5.3.1931, Abt. 301 Nr. 4532, LAS.

16 Report on the 'Reichskonferenz der Hafen- und Wasserarbeiter', Berlin 5.3.1931, Abt. 301 Nr. 4532, LAS.

17 Report by the Preuss. Polizei-Präsident Altona-Wandsbek in Altona, 15.4.1931, Abt. 301 Nr. 4532, LAS.

18 Die Rote Fahne 201, no. 3 (Oktober 1930), copy checked in Reichsministerium des Inneren. Internationale Hafenbüros und Seemannsklubs, Jan. 1930-Nov. 1933, R1501/20224, BArchB.

$19 \S 2$, Statuten der Internationale der Seeleute, Protokoll Nr 82 der Politischen Kommission des EKKI der Sitzung am 20.9.1930, 495/4/52, RGASPI.

20 "Seeleute und Hafenarbeiter hissen die rote Fahne!," Rotes Gewerkschafts-Bulletin (Red Labour Unions Bulletin - Bulletin Syndical Rouge), Sondernummer Nr. 68 (18. Oktober 1930), checked at Reichsministerium des Inneren. Internationale Hafenbüros und Seemannsklubs, Jan. 1930-Nov. 1933, R1501/20224, BArchB. 
The provisional statutes prescribed an active engagement of the ISH in relation to its sections. In contrast to the IPAC-TW, the ISH was to initiate, coordinate and lead international campaigns in support of national strikes and global proletarian solidarity campaigns. The ISH Secretariat was directed to continuously supply its member organisations with agitation and propaganda material as well as to collect information about national conditions and notify its sections about impending national negotiations on wages and tariffs. Moreover, all Interclubs, existing and projected ones, were to be directly subordinated to the ISH Secretariat. ${ }^{21}$

Furthermore, the provisional statutes laid the organisational structures of the ISH and sanctioned a hierarchical relation between its three units, the world congress, the executive committee and the secretariat. The highest decision-making organ was the world congress while the 21-member executive committee issued binding declarations and orders. The 5 -member bureau or secretariat was the operational unit of the organisation. ${ }^{22}$ As a reflection of its global ambitions, the ISH Executive Committee was to be composed of members from the revolutionary trade union oppositions and red unions in "the Arab countries", Britain, China, France, Germany, Greece, India, Italy, Latin America, the Philippines, Scandinavia, the Soviet Union and the USA. The ISH Bureau or Secretariat, nominated after the first meeting of the ISH Executive Committee, see below, George Hardy as Chair (President), and Albert Walter and Auguste Dumay as First and Second Secretary respectively. ${ }^{23}$ The identity of the two members was not revealed as they represented illegal organisations. ${ }^{24}$

\subsection{October 1930: The First Meeting of the Is H Executive Committee}

The IsH Executive Committee summoned for its first meeting immediately after the conference. Six topics were on the agenda. The first one concerned propaganda, and the IsH Executive Committee decided upon Hardy's advice to publish a general declaration on the establishment of the ISH as well as a pamphlet on the fight for 8-hour working days and a pamphlet pinpointing

\footnotetext{
21 "Seeleute und Hafenarbeiter hissen die rote Fahne!"

22 "Seeleute und Hafenarbeiter hissen die rote Fahne!"

23 Bericht über die internationale Konferenz der Seeleute und Hafenarbeiter am 3. Oktober 1930 in Hamburg, no date [ca. October 1930], 534/5/219, 2-5, RGASPI. As with the statues of the ISH, the ECCI had decided upon composition of the ISH Executive Committee well in advance, see $\S 3$, Zusammensetzung der leitenden Organe der Profintern, Protokoll Nr 79 der Politischen Kommission des EKKI der Sitzung am 3.9.1930, 495/4/49, RGASPI. 
the detrimental impact of the ITF in the colonial countries. In addition, the plan was to publish the statutes of the ISH as well as a brochure containing Hardy's speech at the conference together with the aims and objectives of the ISH. Each of the publications were to be published in five languages, namely English, French, German, Spanish and 'Scandinavian'. The Chinese delegate Liao Chengzhi reminded the comrades to also publish in Chinese while Arthur Samsing emphasised the need to publish in Finnish and Icelandic. ${ }^{25}$

The second topic on the agenda was the organisation of an international congress. This was a crucial issue as the forthcoming congress - which according to the 'Basic Principles' had to convene not later than May 1931 - was to proclaim the official formation of the International. This followed communist logics of establishing new organisations - a 'provisional' one was launched at an international conference while its 'official' formation was declared at a subsequent world congress. Consequently, the executive committee and the statutes of the ISH were provisional until the congress. On the other hand, a central prerequisite for calling a world congress was the establishment of red unions in Britain, France, India, Italy and Spain. ${ }^{26}$

The next two tasks concerned the organisation of local work. The ISH Executive Committee decided on the publication of a member bulletin, starting in January 1931. Work at the Interclubs was debated at length but without making any decisions. Finally, the Executive Committee nominated a Bureau or Secretariat as its operational unit. President of the IsH Bureau was George Hardy while Albert Walter was nominated International Secretary. The other bureau members were Auguste Dumay, George Mink and Arthur Samsing. Hardy was to be placed in London, Dumay in Paris, Mink in New York, Samsing in Oslo, while Walter was to run the Is H Secretariat in Hamburg. ${ }^{27}$

The Operational Unit: From Five Bureaus to One Secretariat

The first organisational outline of the ISH projected a decentralised model of five regional bureaus, and was adopted in autumn 1930. The central unit was Albert Walter's International Secretariat (hereafter: ISH Secretariat),

25 Bericht über die Executive-Sitzung der Intenationale der Seeleute und Hafenarbeiter, 3.10.1930, 534/5/219, 6-7, RGASPI.

26 Bericht über die Executive-Sitzung der Intenationale der Seeleute und Hafenarbeiter, 3.10.1930, 534/5/219, 7, RGASPI.

27 Bericht über die Executive-Sitzung der Intenationale der Seeleute und Hafenarbeiter, 3.10.1930, 534/5/219, 7-9, RGASPI. 
occupying an office in the Port Bureau and Interclub at Rothesoodstrasse. Walter was also in charge for operations in Germany, including the moderation of the Interclubs in Hamburg, Bremen and Bremerhaven as well as the maintenance of contacts with the Rhine river transport workers. The main challenge to his work was cooperation with the local party and RGO-officials, who Walter criticised for neglecting work among harbour workers. Nevertheless, Walter was confident in boosting his work and planned to open new Interclubs in Duisburg and Danzig, the latter one as the gateway for illegal agitation and propaganda among Polish seamen. ${ }^{28}$

The second location of operation was London where George Hardy was running the 'English' (i.e., British) Secretariat. Not much is known about its activities or whereabouts. Arguably, it constituted of Hardy's office in Poplar, sharing the same premises with the seamen's section of the Minorities Movement. Among his first accomplishments was the publication of the pamphlet The Fighting International of Marine Workers, containing his speech at the Hamburg conference as well as the resolution on the establishment of the ISH. ${ }^{29}$ Hardy's main task was the reorganisation of work in England and, ultimately, the establishment of a red seamen's union. ${ }^{30}$ Consequently, his first goal being the formation of the Seamen's Minority Movement (SMM). This organisation was subordinated to the Minority Movement while it at the same time constituted the British section of the ISH (see further Section 3.1 in this chapter). However, Hardy's work was slow to take off and had almost immediately run into a standstill as he received orders to travel to Moscow as he had been nominated to work for the RILU Far Eastern Bureau. Walter and Leo Pechmann, the (new) liaison officer at the RILU Berlin Bureau, managed to revoke the order; instead, Hardy was instructed to proceed to Hamburg. ${ }^{31}$

The third location was Paris where Auguste Dumay was running the Latin Secretariat. This unit was projected to monitor and supervise activities in

28 International of Seamen and Harbour Workers (ISH), Monthly Report (MR) for October 1930, 534/5/219, 32, RGASPI; ISH, MR November 1930, 534/5/219, 45-46, RGASPI. Hereafter: ISH, MR.

29 George Hardy, A Fighting International of Marine Workers (Hamburg: International of Seamen and Harbour Workers, 1930).

30 Home Office Warrant, taken out by Scotland Yard 28.10.1930, George Hardy personal file, KV 2/1027, 39a, TNA.

31 ISH, MR October 1930, 534/5/219, 32, RGASPI; ISH, MR November 1930, 534/5/219, 45, RGASPI. Hardy left for Hamburg on 11 November 1930, (Half-burnt) Inf. Notes, 11.11.1930, George Hardy personal file, KV 2/1027, TNA. The ECCI approved Hardy's transfer to Hamburg on 18 November, see §20, Vorschlag der Komfraktion der Profintern, Protokoll Nr 101 der Politischen Kommission des E KKI der Sitzung am 18.11.1930, 495/4/66, RGASPI. 
Belgium, France, Greece, Italy, Portugal and Spain as well as to ignite work in the Belgian and French colonies. Dumay also served as ISH liaison and contact person to the RILU Latin American Secretariat in Montevideo. However, both Dumay's and Walter's connections to South America were patchy if not outright bad, and Walter repeatedly complained about not having received any information from Montevideo. This was frustrating, as Walter wanted to transfer funds to the bureau in Montevideo to cover the expenses for setting up an Interclub in Buenos Aires. ${ }^{32}$

The fourth location was Oslo where Arthur Samsing was heading the Scandinavian Secretariat. ${ }^{33}$ His plan was to open an Interclub at the end of the year in Oslo. ${ }^{34}$ Samsing, too, published a manifesto on the establishment of the IS H. ${ }^{35}$ The fifth member of the bureau was George Mink who monitored the Marine Workers' Industrial Union (MWIU) from his office in New York. ${ }^{36}$

\subsection{Hamburg and Paris: Two Operational Units and the Instructions from Moscow}

The decentralised setup with five bureaus proved soon unpractical. A reorganisation of the operational unit was initiated in December 1930 when Hardy moved to Hamburg. Work at the ISH Secretariat was streamlined and a 'Plan of Immediate Tasks' was sent to Moscow for approval. The Plan listed, among others, the establishment of an international solidarity fund, the formation of port control and action committees, and to set up new Interclubs in Copenhagen, Danzig, Dunkirk, Le Havre, London and Kiel as well as "at other Baltic, Mediterranean, Black Sea, Bosphorus[sic] and other French ports." ${ }^{37}$ According to the Plan, Hardy served as editor of the ISH member bulletin as well as coordinator of activities in the English-speaking countries and the Far East. Walter, in turn, headed the technical apparatus of the ISH Secretariat. Further reorganisations followed in January 1931 after an intervention by Walter in the mandate of the Latin Secretariat and disbandment of the Scandinavian Secretariat. The consequence of the reorganisation in January 1931 was the dissolution of the five-member Bureau and establishment

32 ISH, MR October 1930, 534/5/219, 33, RGASPI; ISH, MR November 1930, 534/5/219, 46, RGASPI.

33 ISH, MR October 1930, 534/5/219, 33, RGASPI.

34 "Besök de Internasjonale sømannsklubber! Ny klubb i Oslo!," Den Internasjonale Transportarbeider 5, no. 15 (November 1930): 4.

35 Internasjonalensmanifest.Tilallesjømennoghavnearbeidere!Ini $<$ Kampinternasjonalens> rekker!, Grå Guld Fagopposition 33.136, Mapp 1. RFO Diverse, ARA.

36 ISH, MR November 1930, 534/5/219, 47, RGASPI.

37 Plan of Immediate Tasks, no date, 534/5/219, 54-57, RGASPI. 
of two Secretariats, one in Hamburg, the other in Paris. Thereafter, Walter at the ISH Secretariat in Hamburg coordinated activities the Baltic area (Estonia, Latvia and Finland) and Scandinavia, Belgium, the Netherlands, Poland and the German-speaking countries whereas Hardy concentrated on the Englishspeaking countries. Dumay, in turn, continued as Second Secretary and head of the ISH Latin Secretariat in Paris; his main task was to monitor activities in the Mediterranean and Black Sea ports. ${ }^{38}$

The ISH Secretariat started to prepare the ground for its immediate work and sent a plan of its intended operations for approval to Moscow. Hardy communicated to the RILU headquarters his impressions of work on the waterfront in France after visiting Paris in late 1930 ("neither the Party nor the CGTU take this work seriously"). In addition, he notified the RILU headquarters that he, together with James W. Ford and Liao Chengzhi, had started to prepare a blueprint for work among colonial seamen, ${ }^{39}$ and informed that he had drafted a resolution on Unemployment Day, a global demonstration called by the communists for 25 February. Lacking addresses to whom he could send the call, he urged RILU headquarters to forward him a detailed list of all harbour workers', seamen's and river workers' unions and "mark them off 1) revolutionary, 2) sympathetic, 3) independent, and 4) reactionary." 40

Furthermore, Hardy informed the members of the IS H Executive Committee in February 1931 about the plans to organised an international conference for harbour workers, scheduled to convene in Hamburg in April 1931. "Our position among the dock workers is not up to the strength of our forces among the seamen," Hardy admitted. Therefore, "our aim is not only to deepen our influence amongst dock and port workers generally, but to form groups or union branches where none exist and the enrolling of large numbers of recruits where they do exist." All sections were obliged to focus on agitation among dockers and to prepare for the upcoming international harbour workers' conference, Hardy reminded. "Mass meetings of port workers can be called and their opinions ascertained by fruitful discussion [...], proposals for the conference can be passed by mass meetings of port workers and resolutions passed endorsing the conference should be sent to the International Secretariat and will be placed before the conference," he assured. Most importantly, those members of the

38 Confidential. Duties and tasks of secretariat members, no date [ca March 1931], 534/5/ 220, 128-129, RGASPI. An analysis of the document reveals that it had been written in Hamburg and sent to Moscow in March 1930.

39 See further Section 4 in this chapter.

40 George [Hardy] to Alexander [Lozovsky], [Hamburg] 20.1.1931, 534/5/220, 14-16, RGASPI. 
ISH Executive Committee "that are not situated in too far distant countries" were to meet before attending the conference. ${ }^{41}$

The IS H Secretariat never received the requested list of addresses. Instead, the RILU headquarters replied by sending detailed instructions in February 1931, clarifying the objectives and tasks of the ISH. "The [RILU] Secretariat notes that the whole of this extremely extensive Plan [of Immediate Tasks] contains a number of points insufficiently concrete, stressing chiefly agitational and propaganda work, not guaranteeing the transfer of gravity of work of the International to the organisational field." Consequently, the RILU's corrections focussed on the operational framework of the ISH and stressed that the ISH was not to replicate the IPAC-TW. Instead, the ISH was instructed to establish and maintain its own global network of sections. In addition, the IS $\mathrm{H}$ was to engage in the (ongoing) anti-war campaign and to infuse its sections to counter-act the imagined impending 'imperialist' attack upon the Soviet Union. Therefore, as part of achieving this objective, the ISH was instructed to expedite the formation of a red seamen's union in England, to establish contacts with the illegal Italian union FILM, to reorganised the MWIU, and to re-establish the (illegal) Greek Seamen's Union. Further, the RILU instructed the ISH Secretariat to develop a plan for strengthening the revolutionary union opposition within the existing maritime trade unions as well as consolidating its outreach in Latin America and in Asia. Last, but not least, the ISH was ordered to create a pool of special instructors to enhance its capacity to directly intervene in the operations of the national sections. The objective of the ISH, the RILU reminded, was to appear as "an organisationally-powerful and politically serious world mass organisation" in order to evolve as "one of the most important factors of the world revolutionary T[rade] U[nion] movement generally, and one of the most decisive weapons in the struggle against war, in particular." 42

Hardy and Walter were baffled. "Dear comrades," they replied, "to excite sweeping criticism regarding the work of I.S.H. Secretariat based upon this limited plan, together with the official documents, and whatever information you have in your possession, we believe has led you to wrong conclusions."43

41 [George Hardy] President to the Provisional Executive Committee Members, Hamburg 5.2.1931, 534/5/220, 61-62, RGASPI. On the projected conference for dock workers, see Call for International Dockers, Hamburg 5.2.1931, 534/5/220, 64-65, RGASPI; Hardy to Provisional Executive Committee Members, Hamburg 5.2.1931, 534/5/220, 61-62, RGASPI. The conference was never organised.

42 Resolution on Work of the Seamen's and Docker's International, 17.2.1931, 534/5/220, $75^{-}$ 76, RGASPI. ISH Secretariat to 'Dear Comrades', [Hamburg] 9.3.1931, 534/5/220, 95, RGASPI. 
Hardy was even more frank in a personal letter to RILU General Secretary Lozovsky: "How could the Profintern Secretariat adopt such a resolution without having any report from the ISH Secretariat?"44 While the Plan had been drafted when Hardy arrived in Hamburg (in mid-December) and thus only reflected two months of work, the ISH Secretariat had since then carried out a lot of work which - seemingly - had not been noted in Moscow. "While the comrade was busy scrutinising his naturally limited materials and drawing upon his very elastic imagination we were in constant contact with USA, England, Belgium, Holland, Norway, Danzig, France, Canada, China, and had communication with Iceland, Denmark, Sweden, Philippines, Australia, Uruguay," Hardy sarcastically remarked. ${ }^{45}$

Although Moscow had criticised the Is H Secretariat for failing to link up with its sections, the comrades in Hamburg rejected the accusations and assured that the ISH Secretariat had already been in contact with the Italian and Greek unions. Assisting the MWIU to overcome its difficulties was impossible, as the ISH Secretariat had no instructor who could sent to the USA. The agitation of the ISH Secretariat in Germany was tactical, "our leaflet to the German dockers was issued to stimulate actions to increase the tempo of the struggle, and to bring the face of the I.s.H. before the German workers. [...] If this is 'duplication' we absolutely reject this interpretation." ${ }^{46}$ Therefore, "instead of being guilty of the charge of losing the contacts I.P.C. had we have considerably extended them far beyond those which existed," Hardy concluded. ${ }^{47}$

Furthermore, interference in England and Scandinavia had yielded some first results. Fred Thompson had changed his earlier negative position of launching a red union. The Scandinavian Secretariat in Oslo had been liquidated and the IsH Secretariat now communicated directly with the sections in Denmark, Norway, and Sweden. Finally, the ISH Secretariat had started to investigate the work of the Interclubs: "We hasten to remind you [that] some of these Clubs have existed under the direct control of the I.P.C.T.W. for double the number of years than the [four] months of existence of the I.S.H., and without achieving this very much desired result."48

44 George [Hardy] to 'Alexander' [Lozovsky], Personal and Confidential, Hamburg, 15.3.1931, 534/5/220, 117, RGASPI.

45 George [Hardy] to 'Alexander' [Lozovsky], Personal and Confidential, Hamburg, 15.3.1931, 534/5/220, 118, RGASPI.

46 ISH Secretariat to 'Dear Comrades', [Hamburg] 9.3.1931, 534/5/220, 96-97, RGASPI.

47 George [Hardy] to 'Alexander' [Lozovsky], Personal and Confidential, Hamburg, 15.3.1931, 534/5/220, 118, RGASPI.

48 ISH Secretariat to "Dear Comrades," [Hamburg] 9.3.1931, 534/5/220, 98, RGASPI. 
Nevertheless, the ISH Secretariat self-critically noted that its apparatus had major flaws that immediately needed to be corrected. The limited staff of the ISH Secretariat was overburdened with daily tasks, effectively blocking it from visiting the national sections in person to give political and organisational advice. The leadership of many national sections, in turn, had failed to respond to the suggestions and instructions of the ISH and rarely reported to the IS H Secretariat, "thus depriving the I.s.H. of its proper role and leadership." However, equally disturbing was "the failure to answer our requests and letters, and the comrades in the U.s.s.R. Secretariat are no exception, including some departments of the Profintern" as well as "the tendency to send in communication and complaints to the Profintern, while withholding them from the I.S.H., and the failure of the Profintern on its part to forward information it receives to the Secretariat of the I.S.H." To overcome these weaknesses, the ISH Secretariat called upon the RILU to strengthen its apparatus by two additional instructors as well as to order the national sections of the Comintern and RILU to carry out a campaign to popularised the Is H "among the masses."49

\subsection{One Centre: The ISH Secretariat at Hamburg}

Moscow's criticism resulted in yet another reorganisation of the Is $\mathrm{H}$ Secretariat. The dual location of its office proved cumbersome, hence all activities were concentrated to Hamburg in March 1931. An application was sent to Moscow for the placement of a third member of the secretariat in Hamburg, the task of the person being to supervise and monitor activities in France, Portugal, Spain, and Yugoslavia as well as in the French, Portuguese and Spanish colonies. In addition, the person was to be in contact with the RILU units in Latin America. The three secretaries were to act as 'referents' and each give special attention to the different categories of sea transport: Hardy to the seamen's section, Walter to the Interclubs and the member to the dockers' section. Apart from these three members, the ISH Secretariat was to be staffed with a technical secretary who could speak and write English, German and French, and preferably Spanish, as well as a stenographer-typist. ${ }^{50}$

Nevertheless, Hardy had never regarded Hamburg to be the ideal location for the headquarters of the Is H. "It must be remembered that our International is primarily English, and your first suggestion to have the

49 ISH Secretariat to "Dear Comrades," [Hamburg] 9.3.1931, 534/5/220, 101-102, RGASPI.

50 Confidential. Duties and tasks of secretariat members, no date [ca March 1931], 534/5/ 220, 128-129, RGASPI. An analysis of the document reveals that it had been written in Hamburg and sent to Moscow in March 1930. 
headquarters in London is the only one to get maximum development," he notified Lozovsky. ${ }^{51}$ Hamburg was not the ideal place for the ISH Secretariat, connections with the national sections were dysfunctional and the ISH was invisible. "I don't want to remain the chairman of the International without leadership. This is a position I would regard as very unsatisfactory," he complained in another letter. The ISH Secretariat should be moved to London, he insisted, as it then could better promote and direct the establishment of national sections. His vision included the nomination of a new management board, composed of himself, Walter, Dumay, one representative of the RILU Berlin Bureau, Harry Hynes of the MWIU, Fred Thompson of the SMM, and James W. Ford of the ITUCNW. ${ }^{52}$

Hardy's main criticism concerned the poor communications between the ISH Secretariat and the national sections. Already Albert Walter had commented upon deficient and insufficient connections from Hamburg, among others to the USA and South America, but assured that his communications system provided alternative contact avenues that enabled him to keep in touch with all ISH sections worldwide. ${ }^{53}$ Hardy, in contrast, claimed that Walter's communications system had severe limitations: "There was heavy criticism [by the $\mathrm{CPGB}$ ] revealing the fact that the connections are still to be created to guarantee an immediate transfer of letters by seamen. I am aware of the other special apparatus existing, but as far as we are concerned we have to build our own." 54

The bad atmosphere at the ISH Secretariat soon paralysed work in Hamburg. Arguably, Hardy's and Walter's background mattered - the former had pursued an international career within the RILU apparatus, the latter had achieved an organisational success through the 'Hamburg' or 'from the bottom'-method. An operational basis did not exist in London, the CP GB as well as the Minority Movement had little capacity in assisting the ISH. Therefore, it made strategically and tactically little sense for the RILU to shift its centre for maritime agitation from Hamburg to the British capital.

Not much is known about the rift between Hardy and Walter as it has left few traces in the internal communications between Hamburg and Moscow. British

51 George [Hardy] to "Alexander" [Lozovsky], Personal and Confidential, Hamburg, 15·3.1931, 534/5/220, 119, RGASPI.

52 George [Hardy] to "Dear Comrade" [Lozovsky]. Very Confidential, Hamburg 30.3.1931, 534/5/220, 143-148, RGASPI.

53 ISH, MR November 1930, 534/5/219, 45-47, RGASPI.

54 George [Hardy] to "Dear Comrade" [Lozovsky]. Very Confidential, Hamburg 30.3.1931, 534/5/220, 143-148, RGASPI. 
intelligence reports, on the other hand, claim that the two loggerheads were at odds about the leadership of the Interclub: Hardy wanted to replace Johannes (Hans) Krause, Walter opposed the idea. ${ }^{55}$ Additional stress for Hardy must have been his 'semi-legal' status in Germany - officially, he informed the police that he working as a free-lance journalist. ${ }^{56}$ Hardy's cover blow up in mid-April when the police conducted a thorough investigation about him, cancelled his permission to work and wanted him deported from Germany. Incapable of running the International Secretariat, Hardy returned to England in early June. ${ }^{57}$

\subsection{Enter Henri Maurice and Adolf Shelley}

Two new comrades arrived in Hamburg during the midst of the power struggle at the IsH headquarters. The first was the Italian Communist Luigi Polano whom the RILU Secretariat had nominated as third member of the ISH Secretariat. Polano had a solid background in maritime work, among others serving as instructor at the Port Bureaus and Interclubs in Odessa (1925), Novorossiysk (1926-1928) and Batumi (1929-1931). After his arrival in Hamburg in April 1930, Polano started to use the pseudonym Henri Maurice. ${ }^{58}$

The second person to arrive in Hamburg was the Polish communist Alfred Bem. He had been politically active in Poland during the 1920s, among others organising the transport workers in Poznan, and belonged to Regional Executive Committee of the (illegal) Polish Communist Party. He started to use the pseudonym Alfred Stolarski after his transfer to the USSR in November 1929. Bem/Stolarski was deputy head of the Balkan section of the RILU from March 1930 to April $1931 .^{59}$ In contrast to Polano, Bem/Stolarski acted as emissary of

55 Minutes 10.10.1932 and 17.10.1932, KV2/1799, TNA; copy of minutes for 17.10.1932 also in George Hardy personal file, KV2 /1027, 84B, TNA. The British intelligence reports are challenging to interpret. Although dated in October 1932, they seem to discuss events in spring 1931; this is evident through crosschecking with internal ISH-minutes sent to Moscow in April 1931. Moreover, Hardy resided in Hamburg only during spring 1931.

56 George [Hardy] to "Alexander" [Lozovsky], Personal and Confidential, Hamburg, 15·3.1931, 534/5/220, 119, RGASPI.

57 (Half-burnt copy) Inf. notes 14.4.1931, 28.4.1931, 8.6.1931, George Hardy personal file, KV $2 /$ 1027, THA; (Half-burnt copy of letter) Hardy to Thompson, [Hamburg] 29.4.1931, George Hardy personal file KV 2/1027, TNA; Polizeibehörde Hamburg an das Reichsministerium des Inneren, Hamburg 12.6.1931, Reichministerium des Inneren. Internationale Hafenbüros und Seemannsklubs, Jan. 1930-Nov. 1933, R1501/20224, 71, BArchB; Hardy, Those Stormy Years, 217.

58 Biografia Luigi Polano, 26.7.1939, 495/221/425, 63-66, RGASPI.

59 See further Wikipedia, "Alfred Brunon Bem," https://pl.wikipedia.org/wiki/Alfred_ Brunon_Bem, checked 19.11.2020. See further entry on Alfred Brunon Bem ("Stolarski") 
the RILU, instructed to monitor and supervise the ISH Secretariat. His mission was strictly confidential and he was never in public connected to the ISH Secretariat. Instead, he set up an underground 'Illegal Secretariat', locared at an unknown site in Hamburg. Bem/Stolarski used the alias Adolf Shelley after his arrival in Hamburg. ${ }^{60}$

Shelley found the ISH Secretariat to be dysfunctional, as Polano had sided with Hardy against Walter. "Practical work [was] impossible," he reported. Most notably, the chaos at the headquarters in Hamburg resulted in the cancellation of the scheduled international conference for harbour workers. Shelley interfered in the quarrel and backed Walter, perhaps instructed by Moscow. British intelligence sources even claim that Hardy received a reprimand from Moscow. ${ }^{61}$

Work at the ISH Secretariat was reorganised after Shelley's intervention. He abrogated the endless and weeklong consultations on strategic and tactical matters, and replaced them with short meetings. ${ }^{62}$ The IsH Secretariat finally managed to publish its member bulletin, the Informations-Bulletin der ISH. Originally projected to be launched in January 1931, its first English and German issues were delayed until June. ${ }^{63}$ In addition, the IS H Secretariat published a small propaganda pamphlet on the Interclubs and the ISH, Der Internationale Seemannsklub - Euer Heim, die ISH - Eure Kampfinternationale, see Figure 11. Nevertheless, the international outreach of the ISH Secretariat was hindered by its limited capacity to publish in any other languages but English and German. Although the colonial sections of the Interclubs in Hamburg and Rotterdam circulated mimeographed magazines and journals in Chinese and Indonesian languages (see Section 4 in this chapter), they lacked propaganda material in Greek, Italian, Portuguese, Romanian and Spanish, Shelley critically noted. ${ }^{64}$

The language issue was never properly resolved. The ISH Secretariat was only capable to communicate in German and English, and the non-German and non-English-speaking sections continuously complained about not

in Buckmiller and Meschkat (eds.), Biographisches Handbuch zur Geschichte der Kommunistischen Internationale.

6o ISH, MR May 1931, 534/5/221, 176, RGASPI. This is the first report with a reference to "Gen[osse] Ad[olf]," i.e., Adolf Shelley.

61 Minutes 10.10.1932 and 17.10.1932, Albert Walter personal file, KV2/1799, TNA.

62 ISH, MR May 1931, 534/5/221, 176, RGASPI.

63 Informations-Bulletin der ISH. Deutsche Ausgabe 1, no. 1 (June 1931).

64 ISH, MR June-August 1931, 534/5/222, 65, RGASPI. 


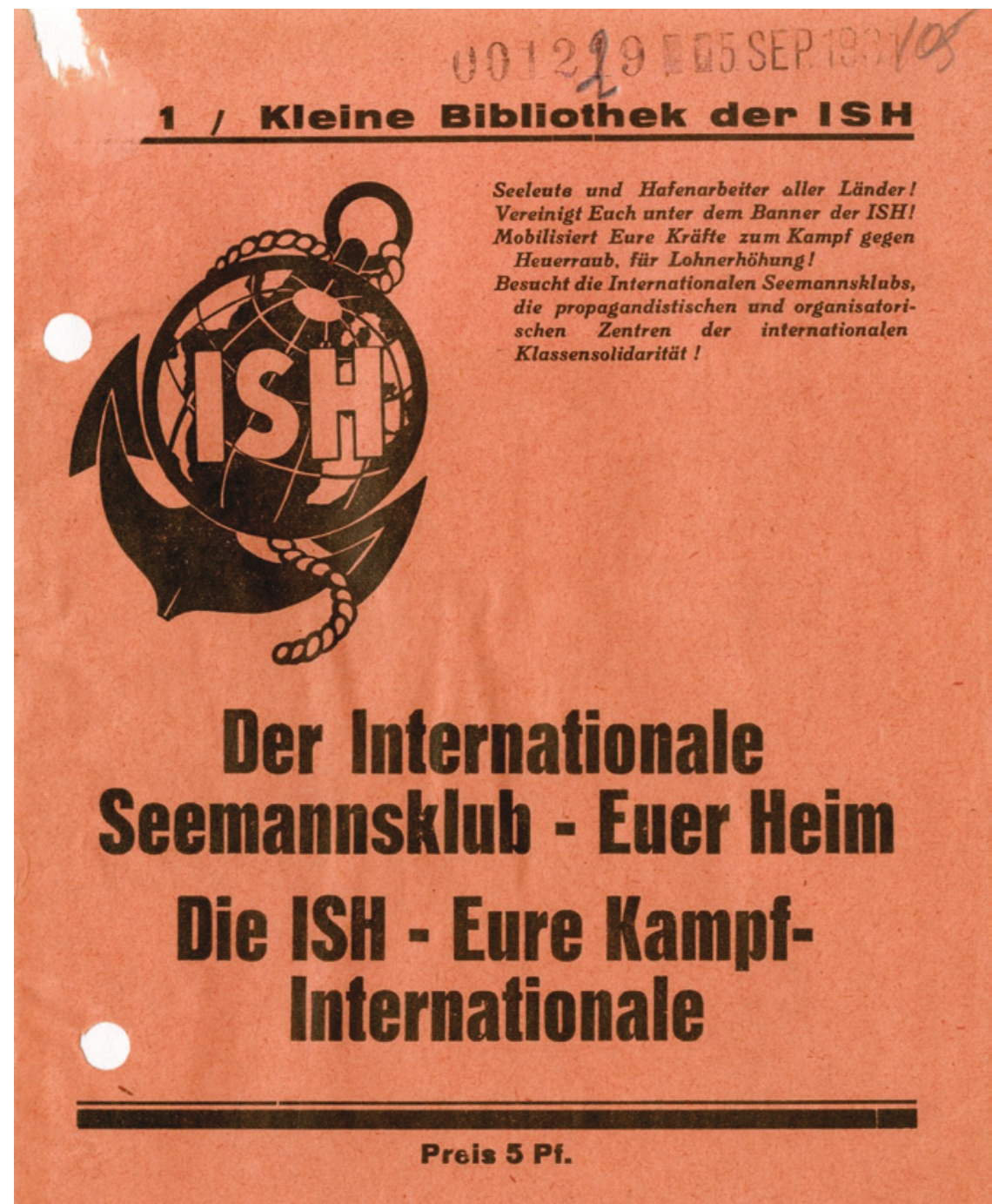

FIGURE 11 Informing mariners about the Interclubs and the ISH, cover of the ISH pocket publication Der Internationale Seemannsklub - Euer Heim, Die ISH - Eure Kampfinternationale, Kleine Bibliothek der ISH 1 (Hamburg, 1931).

receiving material in Spanish, Portuguese or French, or about having trouble in translating German and English directives. Similarly, the Is $\mathrm{H}$ headquarters was in trouble when receiving messages and reports from its sections - it took days if not weeks to have them translated into German and vice versa. Polano was of little help as he was absent from Hamburg for long periods in $193^{1}$ (see below). 
For Shelley, this was a major problem and he urged Moscow to find a solution to it: "We should not be a German-English International!"65

\subsection{The Berlin Connection and the Money from Moscow}

The IsH Secretariat was an integral part of the RILU-apparatus. Two units within the RILU-apparatus supervised and monitored its activities, namely the 'Illegal Secretariat' in Hamburg as well as the RILU Bureau in Berlin. The latter had already served as the liaison office for communication of information and transmission of funds from Moscow to Hamburg. Two persons served as contact persons at the Berlin RILU Bureau. The first one was Max Ziese who already had communicated with Albert Walter's during the 1920s. More importantly, Ziese monitored the oms Bureau in Berlin, camouflaged as the FührerVerlag. ${ }^{66}$ The second one was Leow Smolianski alias Leo Pechmann, ${ }^{67}$ who together with Adolf Shelley and Luigi Polano (Henry Maurice) seemed to have constituted the 'Illegal Secretariat' of the ISH.

The Moscow-Berlin-link was crucial for the IsH. Ideally, the national sections as well as the Interclubs were supposed to generate funds by themselves for covering their expenses. In practice, only a few of them were ever capable of doing so. Most of them relied on subsidies from the ISH headquarters. Moreover, the ISH Secretariat relied on monthly instalments from Moscow via Berlin to pay the salaries of its personnel, see Table 8.

Unfortunately, the available data is both insufficient and difficult to interpret to give a definite answer to how much money was sent on a monthly or an annual basis from Moscow to Hamburg. In early 1931, the ISH Secretariat received a monthly instalment of USD 1,364 to cover its expenses, including the salaries of two secretaries, two instructors and two technical functionaries. In addition, the ISH Secretariat received USD 1,950 each month to be allocated to the various affiliated sections of the ISH. ${ }^{68}$ Consequently, Walter could have received more than USD 3,300 per month or almost USD 40,000 per year.

65 Letter from Adolf [Schelley] to "Werte Genossen," Hamburg 24.11.1931, 534/5/223, 88, RGASPI.

66 Minutes, 25.1.1933, Albert Walter personal file, 6s, KV 2/1799, TNA; [Handling IVA.] Komintern. Schematisk uppställning av organisationen och dess underavdelningar, unpublished report [filed: 2O-12.1941], 11, säPO Äldre Aktsystemet, IV A 2-IV A 4, volym 169, SNA.

67 Schedule of the Principal Revolutionary Organisations Controlled by Moscow (end 1935), 20.4.1936, KV 3/128 International Organisations of Communist Parties, TNA; Komintern. Schematisk uppställning av organisationen och dess underavdelningar, unpublished report [filed: 2O-12.1941], 12, SÄPO Äldre Aktsystemet, IV A 2-IV A 4, volym 169, SNA.

Monthly budget of the ISH, no date [ca. 1931], 534/8/156, 131, RGASPI. 


\begin{tabular}{|c|c|c|}
\hline Month/Year & $\begin{array}{l}\text { Sum paid } \\
\text { (USD) }\end{array}$ & Source (RGASPI) \\
\hline $1 / 1931$ & 500 & $534 / 8 / 177$ \\
\hline $2 / 1931$ & 500 & $534 / 8 / 177$ \\
\hline 3/1931 & 500 & $534 / 8 / 177$ \\
\hline $4 / 1931$ & 500 & $534 / 8 / 177$ \\
\hline $5 / 1931$ & 500 & $534 / 8 / 177$ \\
\hline $6 / 1931$ & 500 & $534 / 8 / 177$ \\
\hline$[\ldots]$ & {$[\ldots]$} & \\
\hline $3 / 1932$ & 300 & $534 / 8 / 216,61$ \\
\hline $4 / 1932$ & 373 & $534 / 8 / 216,61+116$ \\
\hline $5 / 1932$ & 373 & $534 / 8 / 216,61+116$ \\
\hline $6 / 1932$ & 173 & $534 / 8 / 216,168+116$ \\
\hline $7 / 1932$ & 75 & $534 / 8 / 216,200$ \\
\hline $8 / 193^{2}$ & 2,200 & $534 / 8 / 216,227$ \\
\hline$[\cdot]$ & {$[\cdot]$} & \\
\hline $10 / 1932$ & 2,200 & $534 / 8 / 216,283$ \\
\hline 11/1932 & 1,900 & $534 / 8 / 216,306-307$ \\
\hline $12 / 1932$ & 2,200 & $534 / 8 / 216,306-307$ \\
\hline 1/1933 & 1,828 & $534 / 8 / 216,375^{-376}$ \\
\hline $2 / 1933$ & 1,828 & $534 / 8 / 216,375^{-376}$ \\
\hline $3 / 1933$ & 1,828 & $534 / 8 / 216,375-376$ \\
\hline
\end{tabular}

Perhaps this was even the case during the first half of 1931, as documentary sources indicate. ${ }^{69}$ However, figures concerning financial transactions during the latter part of 1932 and early 1933 reveal that this was not necessarily the case. While the ISH was to receive monthly instalments of USD 300 from March to May 1932, this amount was reduced to USD 100 in June and USD 75 in July 1932. For the rest of the year, the allowances increased to more than 1,100 USD per month; in August, October and December 1932, the ISH Secretariat received USD 2,200 per month, and from January to March 1933 USD 1,828 per month. ${ }^{70}$ At least in 1932, therefore, the total amount sent to the ISH Secretariat was perhaps even less than USD 20,00o. On the other hand, special campaigns, such as

69 IS H Budget January - June [1931], 534/8/177, 140, RGASPI.

70 Monthly calculations for RILU transfers, 534/8/216, 61, 116, 168, 200, 227, 306-307, RGASPI. 
the organisation of the ISH World Congress in 1932, were funded through extra payments from Moscow (see below).

Walter distributed the subsidies to the various ISH sections via his courier system. ${ }^{71}$ At times, this proved challenging, especially if direct contacts were difficult to establish or were insecure. This was among others the case with his connections to England. British Intelligence claimed that the ISH Secretariat had sent Hardy a budget for work in Britain of no less than USD 900 in $1931 .^{72}$ The clandestine transfer to the Seamen's Minority Movement was uncovered in November 1931 when British Intelligence traced a contribution of G BP 175 to the Interclub in Amsterdam. One month later, British Intelligence had established that the Amsterdam Interclub served as Walter's intermediary for the transactions, as was revealed in his instructions: "Owing to the special embargo on sending out capital from Germany arrangements were made to send the money on this occasion from Amsterdam."73

The financial basis of the ISH and its sections remained problematic even with the transfer of funds from Moscow. Most of the sections numbered only a few paying members and few sections were capable to pay the rent for the Interclubs and their offices, not to speak about the salaries of their functionaries and staff. The financial constraints restricted their activities and they criticised the ISH Secretariat for lukewarm engagement in their work. A solution to the impasse was discussed by the Is H Executive Committee at its meeting in September 1931. The Is H Executive Committee decided to introduce a new economic blueprint for the organisation. The new regulations required each section to secure its own funding; only the expenses of the Interclubs and their publications were to be covered by transfers from Hamburg. In addition, all sections were obliged to send 1.5 percent of their monthly incomes to the ISH headquarters to cover the costs for running the ISH Secretariat. ${ }^{74}$

\section{Aiming for a Global Outreach - Building National Sections}

The RILU had projected the ISH as a mass organisation with its own national sections and global activities. Membership was restricted, the target group

\footnotetext{
71 A. Walter, 25.1.33/Cross-Reference, Albert Walter personal files, KV 2/1799, TNA.

72 (Half-burnt) Inf. Notes, no date [ca. mid-1931], George Hardy personal file, KV 2/1027, TNA.

73 Minutes 14.11.1931 and 19.12.1931, Albert Walter personal file, KV2/1799, TNA.

74 Letter from Adolf [Schelley] to 'Werte Genossen', Hamburg 24.11.1931, 534/5/223, 86, RGASPI.
} 
being revolutionary trade union oppositions and red unions. As the RILU adhered to the unity principle, i.e., the amalgamation of unions operating in an industrial sector into one industrial union. In principle, this also applied to the maritime unions, namely to bring crew members of merchant vessels, fishing boats and river transport ships as well as all harbour workers into one union. The implementation of this programme proved difficult. So far, the combination of the 'Class-Against-Class'-doctrine in combination with the 'United front from below'-tactic introduced by the IPAC-TW in 1928 had yielded few tangible results in transforming hitherto peripheral opposition groups into mass movements. Consequently, the IS $\mathrm{H}$ was not to replicate and build on the organisational shortcomings the IPACTW; even the most diehard members at the RILU headquarters in Moscow must have recognised that the IPAC-TW was a propaganda tool rather than a member-organisation. This was painfully evident at the October 1930 Hamburg Conference: Few of the delegates represented an established organisation, most of them only small unorganised opposition groups. The ISH Secretariat, therefore, had to start from scratch in its mission to rival and challenge the ITF.

The leading members of the ISH were fully aware of the almost impossible task they were facing. George Hardy's analysis to Alexander Lozovsky in March 1931 clearly addressed the challenges and complicated state of affairs. Echoing Albert Walter's 'from the bottom'-approach, Hardy noted:

We are weak organisationally in almost every country. Our task is to turn these organisations into mass organisations. This can only be done by energetic efforts in each country, by building a base at every port, starting with the most important one first, placing a union delegate on every dock and ship as a step to form ship and dock committees, issuing programmes of immediate demands after thorough discussion by the rank and file as a means to keep down bureaucracy, making every struggle, no matter how small, a means of rallying the masses to wider action, cultivating a wider interest by drawing into the leadership new elements in every country, training cadres and carrying systematic education aiming the masses etc etc. But this will be done by individual attention given to each country. ${ }^{75}$ 
Hardy and Walter soon had to realise that the transformation of small amorphous opposition groups into mass movements lest organised red unions, was a time-consuming process if not uphill battle. Their immediate task was to establish contacts with all those organisations and groups who had been represented at the October 1930 Hamburg Conference. A few months later, they were in regular contact with liaison persons in Europe, North and South America, China and Australia. "It is true [that] many of these communications are not very strong," Hardy noted, "but to some countries we have contacts both open and confidential." ${ }^{\prime 6}$ What he did not highlight was the fact that the difference in regular contacts and (irregular) communications reflected the restricted outreach of the ISH about six months after its launching - sections existed at this point only in those countries with regular connections to the IS $\mathrm{H}$ headquarters.

Commenting upon the slow pace of rocketing the ISH into a militant counterpart to the ITF, Lozovsky identified the lack of commitment by the national parties as a major obstacle. After receiving his assessment in May 1931, the Political Commission of the ECCI ordered him and Osip Piatnisky, head of the International Department of the Comintern, to draft a stern reminder of the utmost importance of focusing on the waterfront and to send it to the Communist Party of Denmark, France, Germany, Great Britain, Greece, Netherlands, Norway, Romania, Sweden, and USA. ${ }^{77}$ Whether their letter had any effect is doubtful.

One country is missing in Hardy's list from March 1931, namely the Soviet Union. The Soviet Russian maritime transport workers' union had already been outside the orbit of the IPAC-TW and its predecessor. Although officially affiliated to the RILU, it was under the control of the Kremlin. An official representative of the Russian union had participated at the 1930 October Hamburg Conference but had not been elected to the presidium of the conference, perhaps being an attempt of downplaying Moscow's presence at the conference. It is also unclear when the Russian union affiliated with IS $\mathrm{H}$ as it was not represented in the ISH Executive Committee or the Is H Bureau/Secretariat. Neither are there any references to the Russian union in the monthly reports of the ISH Secretariat for 1931. Curiously, the 'Russian Water Workers' Union' is listed as an affiliated member in a compilation made at the RILU headquarters in mid1931, see Table 9 .

76 George [Hardy] to Alexander [Lozovsky], Hamburg 15.3.1931, 534/5/220, 118, RGASPI.

77 Protokoll Nr 141 der Politischen Kommission des E KKI der Sitzung am 17.5.1931, 495/4/108, RGASPI. 
TABLE 9 Affiliated and sympathising organisations of the ISH, summer 1931

ISH: Affiliated organisations

USSR: Water Workers' Union

Germany: Einheitsverband

France: FUMP

England: SMM

Scotland: Scottish Seamen's Group (Glasgow)

Danzig: Einheitsverband

USA: MWIU

Greece: Rev. opposition within the seamen's union

Italy: FILM

China

The Netherlands

Sweden

Norway

Denmark

Austria

Latin America: Comite Maritimo y Portuario

Uruguay: Rev. opposition within the seamen's union

Argentina: "Class Unity Committee"

\section{Members}

300,000
9,760
4,675
3,000
61
450
1,200
2,000
$45 \circ$
1,000

"No information"

"No information"

"No information"

"No information"

"No information"

5,000

800

100

\section{ISH: sympathising organisations}

Romania

England: Indian Seamen's Union, London

Australia: Seamen's and Docker's Federation

New Zealand: Rev. opposition within the seamen's union
"No information"

1,8 oo

1,500

2,700

2,700

SOURCE: MATERIALS ON THE WORK OF INTERNATIONAL COMMITTEES, NO DATE, 534/2/ 92, 86-87, RGASPI

\subsection{The Establishment of Sections in Western Europe}

The largest and best organised ISH section outside Soviet Russia was the German one, the Einheitsverband der Seeleute, Hafenarbeiter und Binnenschiffer 
(Einheitsverband). The German section was the only one to include separate units of seamen, dockers, river workers and fishermen. The Einheitsverband was launched at a conference in Altona in January $1931,{ }^{78}$ and started full operations one month later with branches in most German ports. ${ }^{79}$ The first leader of the Einheitsverband was Johannes (Hans) Koschnik (1902-1944) who had a known constrained relationship with George Hardy, mainly due to the latter's criticism of the Einheitsverband's slow progress in expanding its membership and for neglecting work among the harbour workers. ${ }^{80}$ Koschnik and Walter had boasted that the Einheitsverband would list more than 10,000 members by June 1931; ${ }^{81}$ yet by April, the red union only counted some 3,500 members about half of which were seamen. ${ }^{82}$ Extended agitation and propaganda as well as the positive impact of the strike among German seamen in October 1931 resulted in an increase of membership, counting circa 11,000 members in November 1931. Nevertheless, harbour workers were still hard to convince to join the ranks of the Einheitsverband, its members mainly being seamen and river transport workers. ${ }^{83}$ Besides, in accordance with the general instructions of the RILU, the Einheitsverband had focussed on enlisting unemployed seamen and dockworkers, and had been quite successful with this. Nevertheless, although impressive on paper, membership was substantially less than those of the other maritime unions. ${ }^{84}$

Successes were also reported from the Free City of Danzig. Walter had participated at a meeting on 18 January 1931, resulting in the formation of the Einheitsverband der Seeleute und Hafenarbeiter Danzigs (Einheitsverband Danzig). The Einheitsverband Danzig listed 270 members, mainly harbour workers, and immediately affiliated with the ISH. As in Germany, the red union was a minor player among the maritime transport workers in Danzig; about 800 of the 1,800 harbour workers were members of the reformist unions. ${ }^{85}$

78 ISH, MR January 1931, 534/5/220, 13, RGASPI.

79 Weinhauer, Alltag und Arbeitskampf im Hamburger Hafen, 317.

8o ISH, Mr April 1931, 534/5/221, 6o, RGASPI. On Koschnik, see "Johannes Koschnik", in Weber and Herbst, Deutsche Kommunisten, 484-485.

81 ISH, MR February 1931, 534/5/220, 84, RGASPI.

82 ISH, MR April 1931, 6o, 534/5/221, 60, RGASPI.

83 Letter from Adolf [Schelley] to "Werte Genossen," Hamburg 24.11.1931, 534/5/223, 89-9o, RGASPI.

84 Eiber, Arbeiter und Arbeiterbewegung, 186-188. See also Hartmut Rübner, "Arbeit, Milieu und Konfliktverhalten: Syndikalismus in der Schiffahrt bis in die 193oer Jahre," Archiv für die Geschichte des Widerstandes und der Arbeit 16 (2001): 165-212.

85 ISH, MR December 1930, 534/5/219, 72, RGASPI; ISH, MR January 1931, 534/5/220, 10, RGASPI. 
Nevertheless, communist agitation and propaganda paid off, and three months later, the Einheitsverband Danzig had increased to 450 members, of which 80 were seamen. ${ }^{86}$ Walter regraded the IsH section in Danzig to be of strategic importance; the section set up an Interclub whose prime target were Polish seamen, and sought to establish contacts with radical maritime transport workers in Gdynia, the main Polish port. ${ }^{87}$ In 1931, the Interclub Danzig was fully operating, consisting of English, Estonian, Finnish, Latin, Latvian, Polish and Scandinavian sections. ${ }^{88}$

Invigorating activities in France turned out to be complicated. The headquarters in Hamburg received distressing news about the malfunctioning of its two French ISH units, the Federation Unitaire des Marines et Pécheurs (FUMP) and the Interclub in Marseille. The former one was controlled by reformists, while the Federation Unitaire des Ports et Docks, the harbour workers' union, was controlled by "our opponents," i.e, 'trotskyists' or communists who had cut their ties with the Comintern. Although the FUMP was affiliated with the radical French trade union congress CGTU, it declined to join the ISH and had effectively blocked communist agitation within the union. ${ }^{89}$ George Hardy went on an inspection tour to France in early January 1931 to consult with Auguste Dumay. Conditions proved worse than anticipated. The Marseille Interclub was hardly functioning, the FUMP lacked collective leadership, and neither the party nor the CGTU paid much interest in work on the waterfront. Even worse, the local party section in Marseille had occupied the premises of the Interclub. ${ }^{90}$ Dumay complained that the FUMP was not working at all; its finances had collapsed, and Dumay had to cease activities in Bordeaux and Le Havre as well as to stop the publication of the Cri du Marin. He further stressed that the idea of establishing new Interclubs was unrealistic; instead, he wanted to use the limited funds to finance special campaigns for radicalising the waterfront in France. ${ }^{91}$

86 Kurze Übersicht der Tätigkeit der Internationale der Seeleute und Hafenarbeiter im Zeitraum vom Oktober 193 O bis April 1931, 12.5.1931, 534/5/221, 71, RGASPI.

87 ISH, MR June-August 1931, 534/5/222, 64, RGASPI.

88 Länderbericht Danzig, in Zweite Plenartagung der Exekutive der ISH, 10-12.9.1931, 534/ $5 / 224$, RGASPI. A description of the activities by the Scandinavian section is provided in Kurt Mineur, Tukthus. En proletärs minnen (Stockholm: Gidlunds förlag, 1970), 56-59.

89 ISH, MR December 1930, 534/5/219, 73, RGASPI.

90 Hardy to Lozovsky, 20.1.1931, 534/5/220, 14, RGASPI. See further Report of Comrade Hardy upon the Situation in the French Shipping Industry, [Hamburg] 13.1.1931, 534/5/220, 1-9, RGASPI.

Dumay to "Liebe Genossen," Paris 15.1.1931, 534/5/228, 2-6, RGASPI. 
Hardy's investigation must have alarmed the comrades at the RILU Berlin Bureau as they summoned for a meeting in late January 1931 to discuss the bleak prospects for work in France. As an outcome, the RILU Berlin Bureau ordered the ISH Secretariat to send an instructor to Marseille. The main task of the 'special emissary' was to reorganised work in France. ${ }^{92}$

Immediate action did not follow due to the limited capacities of the ISH Secretariat to monitor the operations of the national sections. However, news from France continued to raise concern, and the ISH headquarters decided in April to deploy comrade "Ts" or Thomsen as instructor to Paris. ${ }^{93}$ Thomsen's mission turned out to be difficult. Neither the French Party nor the CGTU appreciated his attempt and rejected any interventions in the FUMP. ${ }^{94}$ Dumay, in turn, was not in favour of moving the FUMP headquarters to Marseille. ${ }^{95}$ Thomsen's second objective was the revitalisation of work in Marseille. This probably followed a plan outlined in Hamburg as he installed the French Soudanese activist Garan Kouyaté as head of the Interclub in June 1931. ${ }^{96}$ Kouyaté was not unknown for the comrades at the ISH headquarters; James W. Ford had already cooperated with him at the Second World Congress of the League Against Imperialism held in Frankfurt am Main in July 1929, perhaps they even met when Ford visited Paris in January 1929. ${ }^{97}$ Dumay, too, had cooperated with him, and Kouyaté had started to make a name as an agitator among black workers in France during the late 1920s. ${ }^{98}$ Impressed by his credentials, Ford invited Kouyaté to Hamburg where he spent a couple of weeks cooperating with Ford before his return to France in June 1931 (see further Section 4 in this chapter). ${ }^{99}$ Kouyaté must have made a positive impact on the comrades in Hamburg as Shelley and Walter recommended him as unofficial third

92 Paul [Max Ziese] to "Herrn Alexander" [Lozovsky], [Berlin] 26.1.1931, 534/4/354, 21, RGASPI.

93 ISH, MR April 1931, 534/5/221, 6o-61, RGASPI. The identity of Thomsen is yet to be established; according to Margain, he was of Danish nationality (Margain, L'Internationale des gens de la mer, 151.).

94 Ts [Thomsen] to "W[erte] G[enossen]," Bericht Nr 12, Paris 13.8.1931, 534/5/228, 163-165, RGASPI.

95 ISH, MR June-August 1931, 534/5/222, 69, RGASPI.

96 Ts [Thomsen] to "Dear Friends," no date [stamped: II/VI/1931], 534/5/228, 50-54, RGASPI.

97 See further Weiss, "Framing Black Communist Labour Union Activism."

98 Rapport du camarade Dumay (des marins) sur le question coloniale, Moscou 13.9.1930, 534/5/217, 49-55, RGASPI.

99 It is likely that Kouyaté, in addition to Liao Chengzhi and Ford, attended at the national conference of water transport workers called by the Eineitsverband and held in Hamburg 7 June 1931, as indicated in the ISH-Bulletin. Although their names is not 
secretary of the FUMP and instructed him to organise the colonial work of the ISH in France. ${ }^{100}$

Kouyatés transfer to Marseille did not turn the tide in France. Dumay had collapsed due to heavy workload and threatened to quit his assignments for the ISH; Kouyaté quarrelled with the local party about funding the Interclub and, to make things worse, the police arrested him at a local rally.101 Work on the waterfront had totally stagnated when Thomsen left France in autumn. The FUMP membership had declined from 6,000 to 1,200; significant local groups existed only in Dunkirk (1,200 members), Boulogne (480), Rouen (250), and Marseille (200). The only positive news were Kouyaté's achievement after his release from detention to enlist black seamen in the FUMP as well as the opening of a new Interclub in Rouen. Moreover, Dumay and the CGTU had accepted the proposal to move the FUMP headquarters to Rouen. The ISH headquarters, in turn, responded by sending comrade "Marcel" as ISH instructor to Rouen and ordered the Marseille Interclub to open an Interclub in Oran, Algeria. ${ }^{102}$

Similar bleak prospects existed in Belgium and the Netherlands. Walter went on a tour to Antwerp and Rotterdam in December 1930 to inspect conditions for work and realised that it had to start from scratch. ${ }^{103}$ His first measure was to transfer the supervision of work in Belgium from the Latin Secretariat to the IsH headquarters and instructed the Latvian seaman Ernst Lambert (19021943) to establish local organisations. ${ }^{104}$ Lambert was an old acquaintance to

mentioned in the article, I assume that Kouyaté was the representative of the "koloniale Neger-Seeleute" (colonial black seamen), Liao the representative of the "chinesischen Wassertransportproletariats" (Chinese maritime transport workers), and Ford, obviously, the representative of the "Neger-Internationale" ("Negro International", i.e., the ITUCNW), see "Reichskonferenz der Seeleute, Hafenarbeiter, Binnenschiffer und Fischer Deutschlands am 7. Juni 1931," Informations-Bulletin der ISH. Deutsche Ausgabe 1, no. 1 (June 1931): 2.

100 NN [probably Adolf Shelley] to Pechmann, [Hamburg] 13.6.1931, 534/5/221, 155-161, RGASPI; AW, Arbeitsbericht des Sekretariats, Hamburg, 16.6.1931, 534/5/221, 183, RGASPI. The signature 'AW' probably refers to $\mathrm{A}=$ Adolf [Shelley] and $\mathrm{W}=$ Walter; documents signed by Walter were marked $\mathrm{Y}$ or W.

101 Ts [Thomsen] to "Werte Freunde," Bericht Nr 9, Paris 20.7.1931, 534/5/228, 168, RGASPI; Ts [Thomsen] to "Liebe Freunde," Bericht Nr 13, Paris 16.8.1931, 534/5/228, 166-167, RGASPI.

102 Kurze Übersicht der Tätigkeit der Internationale der Seeleute und Hafenarbeiter im Zeitraum vom Oktober 193 o bis April 1931, 12.5.1931, 534/5/221, 71, RGASPI; Adolf [Shelley] to "Werte Genossen," Hamburg 24.11.1931, 534/5/223, 95, RGASPI. The identity of "Marcel" is not known.

103 [Walter,] Bericht über die Lage in Antwerpen, Belgien, no date, 534/5/220, 120 - 123; Walter, Bericht über die Lage in Rotterdam, 13.12.1930, 534/5/221, 175, RGASPI.

104 Minutes, 16.12.1930, Albert Walter personal file, KV 2/1799, TNA. 
Walter; he had left Latvia in 1918 and worked on British and Dutch vessels since then. He was a member of the local smm branch in Antwerp and had participated at the 1930 October Hamburg Conference. ${ }^{105}$ Lambert immediately launched a broadside campaign in The International Seafarer, a journal published by the SмM branch in Antwerp (and probably edited by Lambert), in support for the establishment of a red seamen's union in England: “The Seamen's Minority Movement itself is not a trade union, but will become as such in the nearest future ... a real militant organ in the class struggle."106 Not surprisingly, Lambert's campaign received little positive acclamation. British authorities declared him persona non grata and arrested him when visiting England in February 1931. Released in April, he returned to Antwerp only to be expelled by the Belgian authorities in June, and spent the following months illegally and jobless in Hamburg until he moved to Rotterdam in late September.107

Meanwhile, the Belgian and Dutch comrades started to report some success in their endeavours to start up waterfront activities. The Antwerp Interclub was moved to a new location with more suitable facilities than the old one at the end of 1930. In January 1931, a small revolutionary opposition group had been established within the Belgian Seamen's Union, headed by comrade Verkeest who was also in charge of the Interclub. ${ }^{108} \mathrm{Six}$ months later, the opposition counted 125 members and constituted the ISH section in Belgium. Work among the harbour workers, on the other hand, backfired in Antwerp; as in France, 'Trotskyists' controlled the union. ${ }^{109}$ Similar conditions prevailed at first in Rotterdam: No Interclub and no work among seamen. Albert Walter's commissioned the Dutch communist Joseph (Joop) Rimbertus Schaap (18981943) to re-establish work in Rotterdam. ${ }^{110}$ A breakthrough was achieved in April 1931 when Schaap reopened the Interclub in Rotterdam and established

105 NN to Walter [introducing Ernst Lambert], 26.9.1930, 534/5/232, 66, RGASPI.

106 The International Seafarer. Organ of the SMM Antwerpen group 2, no. 2 (February 1931), filed in Ernst Lambert (Avotin) personal file, KV 2/3729, TNA.

107 Minutes, 30.3.1931, 25.6.1931, 3.8.1931, 1.10.1931, Ernst Lambert (Avotin) personal file, KV $2 /$ 3729, TNA.

108 Kurze Übersicht der Tätigkeit der Internationale der Seeleute und Hafenarbeiter im Zeitraum vom Oktober 193 O bis April 1931, 12.5.1931, 534/5/221, 74, RGASPI; ISH, MR May 1931, 534/5/221, 183, RGASPI.

109 ISH, MR January 1931, 534/5/220, 12, RGASPI; ISH, MR May 1931, 534/5/221, 183, RGASPI.

110 Bericht über die Lage in Rotterdam, Holland. Aussprache mit der Leitung der Holländischen Partei, Hamburg 13.12.1930, 534/5/221, 175, RGASPI. On Schaap, see Etienne Verhoeyen, “'De zaak Block en Celis'. De moeizame relatie van de Antwerpse gerechtelijke politie met de Gestapo (1938 - 1941). Deel 1," in Cahiers Inlichtingenstudies/Cahiers d'études du renseignement 2, eds. Marc Cools et al. (Antwerpen, Apeldoorn: Maklu, 2012), 19 . 
a revolutionary opposition group in the seamen's union. Walter sent an instructor - probably Liao Chengzhi - to Rotterdam with special order to start work among Chinese seamen. ${ }^{111}$ First results were promising: The opposition counted already 275 members by the end of May. Still, it was a long way for the opposition to gain recognition - the social democratic seamen's union listed 13,000 members, the Catholic seamen's union 2,o9o and the nationalist one $1,75^{\circ} .112$

\subsection{Towards a Red Seamen's Union in Britain?}

The situation in England raised also concern at the ISH headquarters. A promising start was the formation of the Seamen's Minority Movement or SMM in 1929. One year later, the SMM was recognised as the ISH section in England. Following a nationwide campaign, the SMM listed some 2,000 members by the end of $1930 .^{113}$ However, the transformation of the SMM into an outright red union backfired almost immediately. In part, this was due the CPGB leadership opposing Hardy's nomination as Secretary of the Minority Movement. Harry Pollitt and William Gallagher, two leading members of the CPGB, tried to block Hardy's nomination at a meeting in Moscow in August 1930. RILU General Secretary Lozovsky intervened and suggested that Hardy was to return to England on the payroll of the RILU and to operate organisationally outside the Minority Movement. ${ }^{114}$ Pollitt agreed to this but sent a telegram to Berlin asking them to notify Otto Ville Kuusinen at the Comintern headquarters that the CPGB leadership was "unanimous against proposal making him [i.e., Hardy] Second Secretary MM."115 The ECCI, in turn, overruled the protest and backed Hardy's nomination as first secretary of the Minority Movement in November $1930 .^{116}$

Hardy's first sojourn as main organiser of the radical waterfront in Britain was a short one. Returning to England after the launching of the ISH, and amply supplied with financial resources, his first ambition was to establish an Interclub in Poplar, London. For this, he approached the leaseholder of $27 \mathrm{a}$ Grundy Street with a view to taking over the premises. In addition, the ISH

\footnotetext{
111 ISH, MR April 1931, 534/5/221, 62-63, RGASPI.

112 ISH, MR May 1931, 534/5/221, 181-182, RGASPI.

113 ISH, MR December 1930, 534/5/219, 72-73, RGASPI.

114 (Half-burnt) Inf. Notes, no date (ca. January 1931), George Hardy personal file, KV 2/ 1027, TNA.

115 MASK 25.9.1930, intercepted telegram from Pollitt to comPARTY Berlin, George Hardy personal file, KV 2/1027, 37b, TNA.

116 Protokoll Nr 8o der Sitzung der Politischen Kommission des EKKI vom 11.11.1930, 495/4/ 50, RGASPI.
} 
Secretariat was prepared to supply him with more money if he and his mates succeeded in enrolling 5,000 new members within a period of six months. The target, therefore, was set for a campaign to break, at all costs, the NUs. ${ }^{117}$ Equally important was the reorganisation of the Indian Seamen's Union in London, being the task of N.J. Upadhyaya under the direction of Hardy.118

As Hardy already relocated to Hamburg in mid-November 1930, he could not himself in person monitor the campaign for launching a red seamen's union. Instead, Fred Thompson and other smm functionaries took over as organisers of the campaign. However, to Hardy's big disappointment, the leadership of the Minority Movement rejected the idea of a red union. Hardy sarcastically remarked to RILU General Secretary Lozovsky: "There is too much talk of 'preparing the basis' etc instead of telling seamen that every member who joins the SMM does so as a definite act of forming the new union."119 In his mind, the leading comrades of the Minority Movement had totally misunderstood the purpose and tactical outline of the campaign: "The SMM is not organisationally the central point to emphasise. The SMM is only a temporary vehicle for the enrolled members previous to calling port and district conferences to definitively create organisational forms of the new union." ${ }^{120}$ Hardy visited England for a meeting with Gallagher in March 1931 and the Minority Movement (probably after having received a reminder from Moscow) finally backed the plan: Regional conferences were to be held in July and August; a national one to be organised in September at with the new red seamen's union was to be established. ${ }^{121}$

However, progress was slow and the Is $\mathrm{H}$ headquarters drafted a stiff reminder but, after Pechmann's intervention, never sent it to London. ${ }^{122}$ Hardy's deportation from Germany in early June infused new energy into the campaign. ${ }^{123}$ In addition, Hardy planned to boost work among Indian seamen. He therefore drafted a leaflet where he invited them to join the new (projected) seamen's union, and ultimately form a union of their own. ${ }^{124}$

\footnotetext{
117 J. Bell to Sir Veron Kell, Report re George Hardy, 12.1.1932, George Hardy personal file, KV 2/1027, 66A, TNA.

118 (Half-burnt copy) Inf. Note 7.11.1930, George Hardy personal file, KV 2/1027, TNA.

119 Hardy to Lozovsky, 20.1.1931, 534/5/220, 15, RGASPI.

120 (Half-burnt copy of letter) Hardy to Watkins, 31.1.1931, George Hardy personal file, KV $2 /$ 1027, TNA.

121 (Half-burnt copy of letter) Gallagher to G. Allison, 21.3.1931. Hardy arrived at Harwich on 17 March and returned on 27 March 1931. George Hardy personal file, KV 2/1027, TNA.

122 ISH, MR May 1931, 534/5/221, 176, 185, RGASPI.

123 (Half-burnt) Inf. note 3.7.1931, George Hardy personal file, KV 2/1027, TNA.

124 (Half-burnt) Inf. note, no date (ca. July 1931), George Hardy personal file, KV 2/1027, TNA.
} 
Nevertheless, the expected results were not forthcoming, and according to a police fink's report, Hardy and Thompson were expected to send a memorandum to Moscow about their difficulties. Although Thompson and a few other comrades were continually visiting ports, few of the participants at "enthusiastic" propaganda meetings would remain for longer periods sympathetic to the SMM or even join it, the police fink noted. "It has been found in the great majority of ports that, soon after Thompson and others have departed, the groups formed ceased to function," the main reason being mundane - a lack of sufficient funds to set up an efficient local organisation completed with paid staff and office. The prospect for launching the projected union according to the original time schedule was as far away as ever before: "From what I have seen and been told about the movement by comrades actively working in the group, it will not cut much ice with its present ship shod [sic] organisation."125 In August, Hardy and Thompson were reported of having a dispute about the date for launching the new union; ${ }^{126}$ in early September, Hardy reported to "either Berlin or Moscow" that it would be futile to launch a new union due to the poor organisation in the ports, and warned that it only could end in the collapse of the SmM. ${ }^{127}$ Besides, Hardy was disappointed about Upadhyaya's bleak achievements in agitating among Indian seamen, and proposed to the CPGB Colonial Commission to have him replaced by comrade Gunawardena. ${ }^{128}$

The ISH Secretariat, in contrast, had received some positive news about the local activities of the SMM. Fred Thompson reported in February 1931 that branches had been established in most ports, SMM membership had increased to 3,000, and the establishment of Interclubs was in full swing in Hull, Liverpool, London, Newcastle and South Shields. ${ }^{129}$ However, the euphoric news soon turned out to be an overstatement. The Interclub in London at 233, High Street, Poplar mainly attracted unemployed youths rather than "real" seamen, its premises being described by a police fink as "beginning to get dirty" and "a certain amount of 'dry rot' has set in there."130 No work was conducted

\footnotetext{
125 Report by “F.1," 18.7.1931, George Hardy personal file, KV 2/1027, 43A, TNA.

126 (Half-burnt) Inf.note 13.8.1931, George Hardy personal file, KV 2/1027, TNA.

127 British Intelligence notes, 12.9.1931, George Hardy personal file, KV 2/1027, 47 A, TNA.

128 (Half-burnt copy) Inf.note, 24.8.1931, George Hardy personal file, KV 2/1027, TNA. However, hardy changed his mind at the next meeting of the Colonial Commission and decided to give Upadhyaya one more chance in the Indian Seamen's Union ([Half-burnt copy] Inf. note, [?]10.1931, George Hardy personal file, KV 2/1027, TNA.

129 ISH, Mr February 1931, 534/5/220, 86, RGASPI; Kurze Übersicht der Tätigkeit der Internationale der Seeleute und Hafenarbeiter im Zeitraum vom Oktober 1930 bis April 1931, 12.5.1931, 534/5/221, 72, 75, RGASPI.

130 Report by “F.1," 18.7.1931, George Hardy personal file, KV 2/1027, 43A, TNA.
} 
among harbour workers and the Interclubs turned out to be mere offices of call ("Anlaufstellen") rather than outright clubs; "and all of them are badly run, even the one at Poplar," Thompson had to admit. ${ }^{131}$ SM m membership fluctuated greatly, and by November, only $35^{\circ}$ of its 3,60o members were paying their monthly fees. ${ }^{132}$

\subsection{The Dissolution of the Scandinavian Secretariat and Work in Northern Europe}

The push of the IsH towards Northern Europe faced initial challenges. Gone were the previous units of the IPAC-TW, not least the Interclub in Copenhagen. The situation in Denmark and Sweden was unclear, that in Norway pathetic. The key facilitator in Denmark, Richard Jensen, was marginalised due to the struggles within the Danish Party whereas the split of the Swedish Party in fall 1929 had resulted in a collapse of the revolutionary trade union opposition in the Swedish seamen's and stokers' unions. Even worse, Arthur Samsing, who headed the ISH Scandinavian Secretariat in Oslo, reported that he had no contacts with the comrades in Denmark and Sweden. As few signs of improvement reached the ISH headquarters, Albert Walter decided to disband the Scandinavian Secretariat in April 1931 and instructed Samsing to limit his work to Norway only. However, the publication of Den internasjonale Transportarbeider, renamed in January $193^{1}$ as Internasjonal Sjøtransportarbeider - Organ for Sjøfolkenes og Havnearbeidernes International, was to continue, see Figure 12. The IS H headquarters, in turn, were to open direct connections with the revolutionary opposition groups in Denmark and Sweden. ${ }^{133}$

The decision of dissolving the ISH Scandinavian Secretariat occurred during the midst of an industrial conflict in Norway. The revolutionary opposition in Norsk Matros og fyrbøterunion, the Norwegian Seamen's and Stokers' Union, had established itself as Søfolkens RFo (Mariners' Revolutionary Trade Union Opposition) in late 1930. Samsing concentrated his main effort on launching a broadside national campaign as new tariffs were up for negotiations in Norway - the union leadership proposed a prolongation of the tariffs, the shipping industry demanded substantial cuts, and the communists called for salary increases. The initial position of the communists was rather weak - out of the previous 67 ship cells, only ten remained. The Søfolkens RFo had little influence in the union and the Norwegian Party was lukewarm in supporting work

\footnotetext{
131 Report by "F.1," 15.9.1931, George Hardy personal file, KV 2/1027, 46A, TNA.

132 ISH, MR September 1931, 534/5/223, 24, RGASPI; Adolf [Shelley] to "Werte Genossen," Hamburg 24.11.1931, 534/5/223, 91, RGASPI.

133 ISH, MR April 1931, 534/5/221, 73, RGASPI.
} 


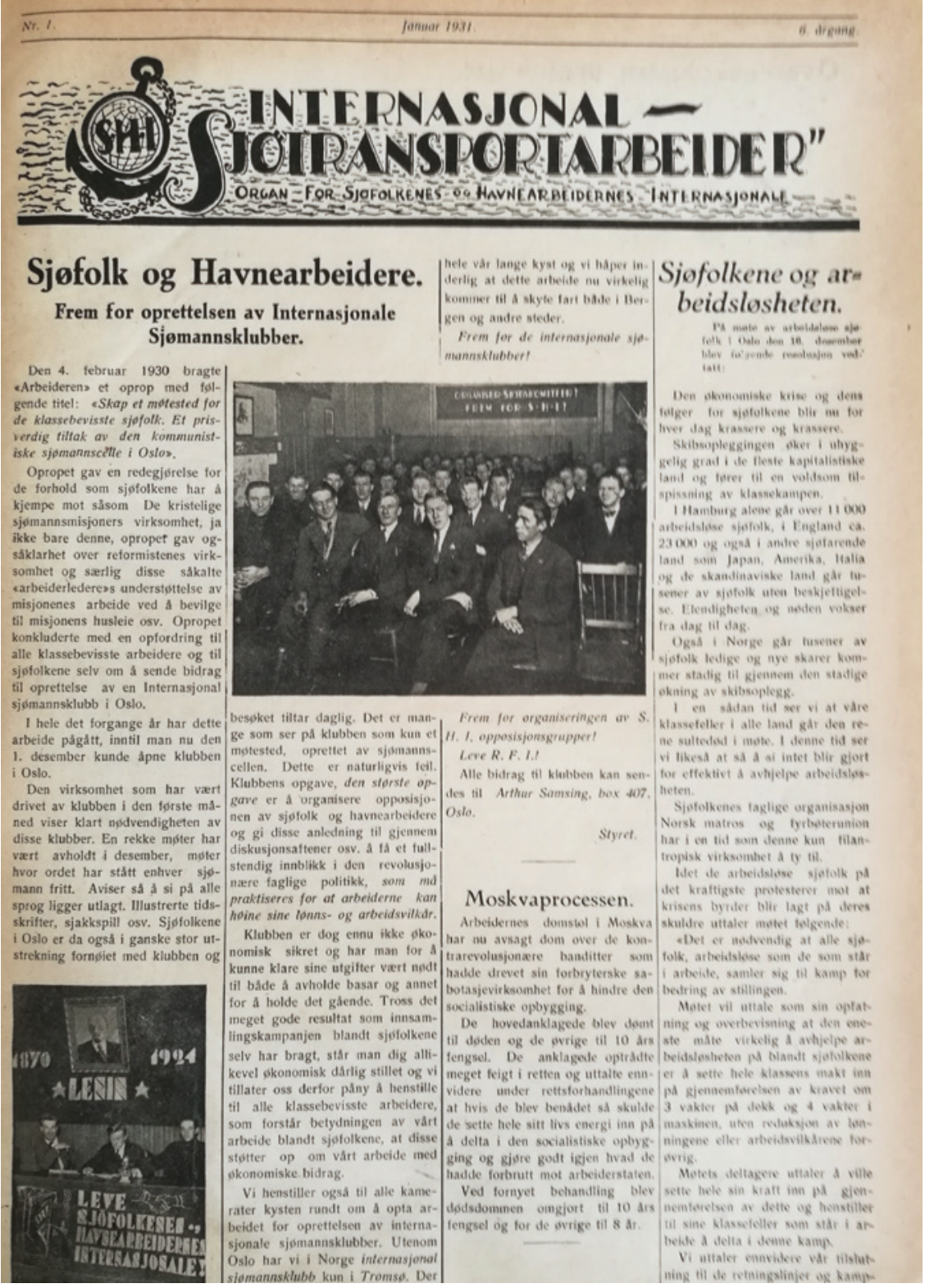

FIGURE 12 Internasjonal Sjøtransportarbeider-Organ for Sjøfolkenes og Havnearbeidernes International, journal published by the Scandinavian Section of the IS $\mathrm{H}$. 
on the waterfront. ${ }^{134}$ The shipping industry attempted to break the unions by declaring a lockout. Negotiations broke down on 3 March 1931, followed by a boycott of Norsk Matros og fyrbøterunion. The Comintern and RILU headquarters ordered the Norwegian Party and the communist trade union opposition to prepare for actions. Communist strike tactics were to follow the 'Unite front from below'-tactic, organised and un-organised seamen were to form communist-led strike committees. Activities were concentrated to Bergen, the main port of the Norwegian coastal shipping fleet. Here, the communists dominated the local branch of the union. On 7 May, the Bergen branch called for a strike on the coastal fleet. However, union leadership rejected the call and the strike failed miserably. The communist opposition was pushed aside and was incapable of stopping the commencement of negotiations. The conflict ended in August/September with the defeat of the shipping industry - and the almost total marginalisation of the Søfolkens RFO. The union excluded all communist members who refused to sign a declaration of support for the union leadership, affecting heavily the Bergen and Oslo branches where the communists had a strong backing. ${ }^{135}$ Samsing protested vehemently but only gained the support of the Danish revolutionary opposition. ${ }^{136}$

A far more promising development was at the same time noted in Denmark. New Interclubs had been set up in Odense (summer 1930) and Copenhagen (late fall 1930). Richard Jensen, who had remained his dominant position within the Søfyrbødernes Forbund (Danish Stokers' Union), managed to unite the revolutionary trade union opposition within the union by summer 1931. Although his attempt to topple its socialist leadership failed at the union congress in August, the opposition remained strong with Jensen in control of the Copenhagen branch of the union. Less promising was the situation within the Sømændenes Forbund (Seamen's Union) and the Havnearbejdernes Fællesforbund (Harbour Workers' Union), the Communist revolutionary trade union opposition counted 55 members in the former and only 42 members in the latter union. The three revolutionary trade union opposition groups merged during summer 1931 and subsequently constituted sections of the Søfolkenens og havnearbejdernes RFO (The Mariner's and Dockers' RTUO), with branches in Aalborg, Copenhagen, Esbjerg, Odense and Sønderborg. Following a decision made at its first annual conference ("Landskonferens") in September 1931,

134 Walz, Bericht über die Vorbereitung des Kampfes bei den Seeleuten, 18.3.1931, 495/31/134a, 61, RGASPI.

135 Olstad, Vår skjebne ivår hand, 141-142, 214-216.

136 "Den norske søfolks kamp under den revolutionaere oppositions ledelse," Lanternen 6, no. 8 (1931): 11. 
the Sø- og Havnearbejderen, the local RFO-journal published by the Esbjerg Interclub, became the mouthpiece of Søfolkenens og havnearbejdernes RFO, renamed in early 1932 as Rød Kurs (see Figure 13), while the Lanternen, hitherto published by the Copenhagen Interclub, was transformed into the organ of the revolutionary mariners. ${ }^{137}$

The formation of a revolutionary trade union opposition within the maritime unions in Sweden, too, gained momentum in 1931 although the date of its constitution is unclear. Some loosely organised and (minority) communist-led groups continued to exist after the split of the Communist Party. Communist agitation made the headlines in late 1930 when the unions expelled two of its leaders, Knut Björk and Bernt Svensson (see Chapter 3.2.2). The first manifestation of an existing organised opposition was at the First of May parade in 1931 when the revolutionary trade union opposition marched as an own group behinds its own banner. An Interclub was set up in Stockholm and opened its doors on 1 May; a second one was opened in Gothenburg in December 1931. The (minority) Communist press noted that opposition groups had been established in "all ports along the coast" by mid-summer 1931. The formation of the Sjötransportarbetarnas RFO climaxed at the first conference of the opposition ("Landskonferens") in August/September. The publication of the first issue of the Hamn- och sjöproletären in October 1931 finalised the formation of the Sjötransportarbetarnas RFO, see Figure 14. ${ }^{138}$

The slow start in Scandinavia was debated at length at the meeting of ISH Executive Committee in early September 1931. ${ }^{139}$ The meeting hastened in the effective formation of the revolutionary trade union opposition within the Scandinavian national maritime unions, e.g., the Søfolkenes og havnearbejdernes revolutioncere fagopposition in Denmark, the Sjøfolkens revolusjoncere fagopposition in Norway and the Sjötransportarbetarnas revolutionära fackopposition in Sweden. The IS H Executive Committee ordered each of the national communist - revolutionary - trade union oppositions, shortened as RFO, to establish organisational structures, including a national secretariat and local sections or groups. However, as the RFO:s were not independent bodies or trade unions, none of the Scandinavian RFO:s ever applied for membership in the ISH as this could only have been done in the name of a union. On the other hand, the Scandinavian RFO:s claimed in their public appeals and on the front pages of their journals and magazines to constitute the national sections of the ISH - as did the ISH in its own publications. ${ }^{140}$

137 Weiss, För kampen internationellt!, 268-273, 443, 448.

138 Weiss, För kampen internationellt!, 284-286, 459, 459.

139 Zweite Plenartagung der Exekutive der ISH, 10-12.9.1931, 534/5/224, 52, RGASPI.

140 See further Weiss, För kampen internationellt! 


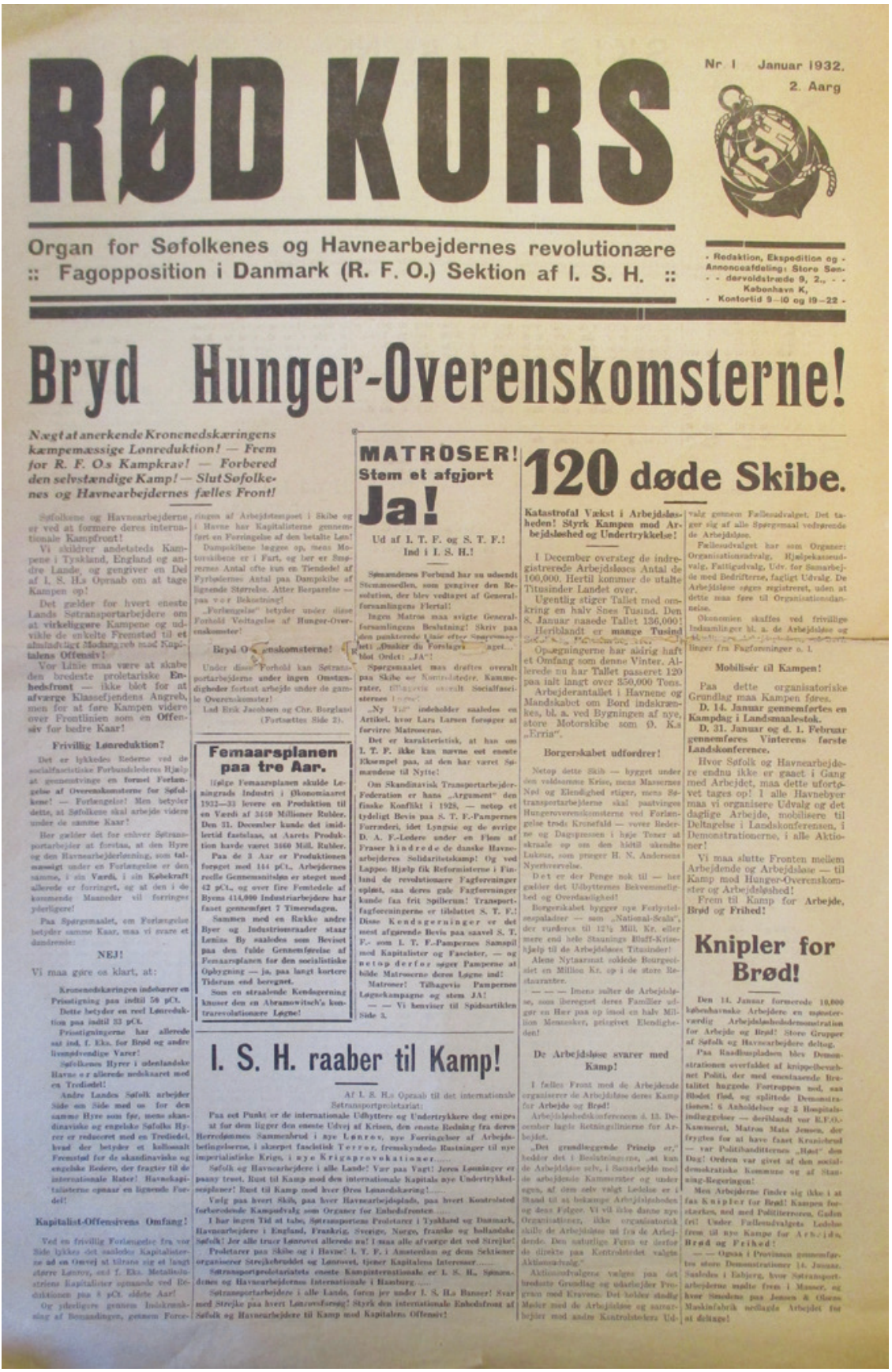

FIGURE 13 Rød Kurs, the organ of the Danish section of the ISH. 


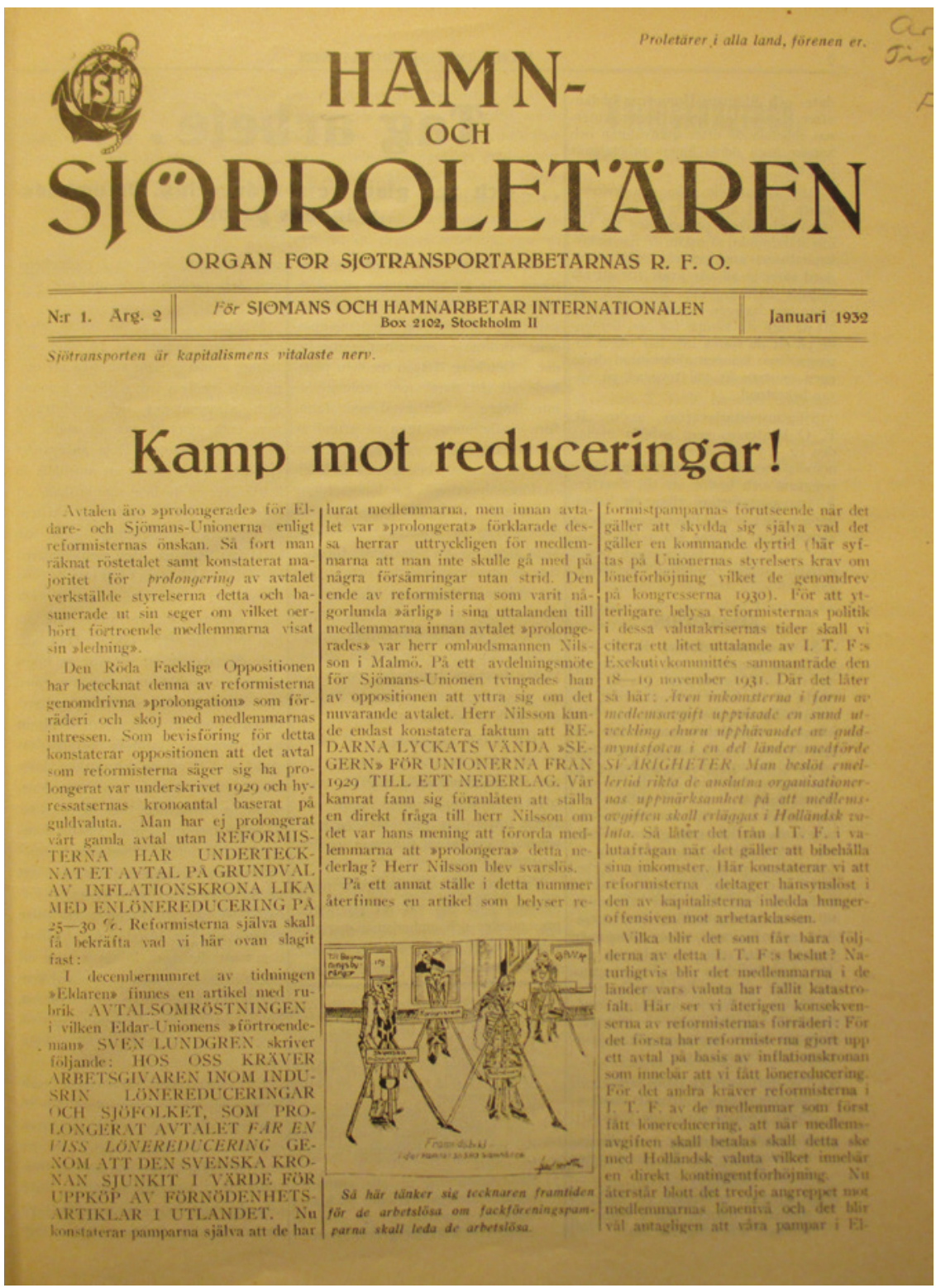

FIGURE 14 Hamn-och sjöproletären, the organ of the Sjötransportarbetarnas RFO, the Swedish section of the ISH. 
The situation in the Baltic Sea region, in turn, was a complicated one and the IS $\mathrm{H}$ headquarters had few if any directs links to Estonia, Finland, and Latvia in $1931 .{ }^{141}$ The situation in Finland had been very disappointing. Communist party and trade union activities was illegal since the end of the Civil War in 1918. Nevertheless, the communists circumvented the ban and had via radical left-wing socialist organisations managed to gain a strong position within the unions during the 1920s. The chaos of 1929 unleashed by the implementation of the 'Class-Against-Class'-doctrine heavily affected the hitherto communistdominated unions, not least in the Finnish Seamen's and Stokers' Union (Suomen merimiesten ja lämmittäjien unioni/Finska sjömans- och eldareunionen). Finnish Communism split into two fractions, the left-wing socialists and the Comintern-loyal communists. The tug of war between the two fractions also paralysed the union in 1930. The communists pushed for the implementation of the Strassburg Theses, the left-wing socialists including union leader Karl Ahonen rejected them. When Ahonen and the union leadership voted against the acceptance of the so-called Copenhagen treaty on cooperation between the Scandinavian, Finnish and Russian water transport unions, the communist fraction deposed the left-wing socialist leadership at the union congress in May 1930. As a counter-measure, the left-wing socialist and social democratic members established a new union and registered it with the same name as the old union. The communist-controlled old union lingered on during summer but its existence was cut short by the introduction of the so-called Communist Laws by the Finnish Parliament in September 1930. Former members of the old union joined the new union - never openly as Communists and the union leadership reported about the existence of a cryptic 'revolutionary trade union opposition' (Vallankumouksellinen ammattillinen oppositio, VAO) in autumn 1931. Not much is known about the activities of the VAO and at least Albert Walter and the ISH headquarters had, at this point, no connections to it. One year later, Hamburg emerged as the centre for not only the Finnish but also the Estonian and Latvian revolutionary opposition as will be outlined in Section 6.3 in this chapter. ${ }^{142}$

\subsection{Southern Europe}

Following the strategic outline of the ISH, the ISH Latin Secretariat in Paris was responsible for coordinating and supervising the activities of the ISH sections in the Mediterranean countries (Greece, Italy, Portugal, and Spain).

141 ISH, MR September-October 1931, 534/5/223, 26, RGASPI.
142 Weiss, För kampen internationellt!, 294-300. 
Top priority was the reactivation of the illegal Italian union FILM. Already in January 1930, the RILU ordered its reorganisation and emphasised the need for agitation and propaganda among Italian seamen residing outside Italy. About 40,000 of them, the RILU stated, had emigrated from Fascist Italy and worked on vessels of other nations. So far, the FILM had been inactive and the IPAC-TW instructed the FILM headquarters in Marseille to cooperate with the Interclubs in order to start illegal activities in Italy and among Italian seaman. ${ }^{143}$ However, work in Marseille was slow to take off. Meanwhile, the Interclubs in Soviet Black Sea ports had organised the largest units of the FILM..$^{144}$

Other operational areas in the Mediterranean were also difficult to open up. Anarcho-syndicalists controlled the maritime unions in Portugal and Spain; the communist-led fractions were marginal and their contacts with the ISH weak. A different situation prevailed at first in Greece where the revolutionary trade union opposition within the seamen's union affiliated with the ISH. The position of the opposition seemed to be strong - listing about 2,00o of the union's 4,500 members, with major branches in Piraeus (800 members) and Thessaloniki (40o members). However, the clampdown on communist trade union activities by the Greek government and the arrest of the leaders of the opposition paralysed activities. ${ }^{145}$ On the other hand, the opposition had managed to set up an Interclub in Piraeus and planned to open another one in Thessaloniki. The ISH Secretariat reacted promptly and sent an (unidentified) instructor to Piraeus. ${ }^{146}$ Nevertheless, the comrades at the ISH headquarters were not impressed by the achievements of the IS $\mathrm{H}$ Latin Secretariat and sent Luigi Polano on a mission to Paris in October 1931. ${ }^{147}$

The ISH also projected to establish opposition groups in ports along the Danube. The core idea was to establish a transnational network parallel to the one projected for the River Rhine, originally initiated at a conference held in Duisburg in February 1930 (the 1930 Duisburg Conference, see Chapter 5.4.1). An opportunity to form the Danube link opened when the local trade union opposition groups in Austria contacted Albert Walter in January 1931 and proposed

\footnotetext{
143 NN to Comité de reorganisation et de reconstitution de la FILM, 2.2.1930, 534/5/217, 10, RGASPI; Theses sur l'activité de la FILM, 16.2.1930, 534/5/217, 11 - 15, RGASPI; NN to "Werte Genossen," 14.6.1930, 534/5/216, 31, RGASPI.

144 ISH, MR April 1931, 534/5/221, 61, RGASPI; Kurze Übersicht der Tätigkeit der Internationale der Seeleute und Hafenarbeiter im Zeitraum vom Oktober 193 o bis April 1931, 12.5.1931, 534/5/221, 72, RGASPI.

145 German translation of Comrade Maurice's [Luigi Polano] report on the situation in Greece, 23.8.1931, 534/5/222, 72-73, RGASPI.

146 ISH, MR September - October 1931, 534/5/223, 24, RGASPI.

147 Adolf [Shelley] to "Werte Genossen," Hamburg 24.11.1931, 534/5/223, 88-89, RGASPI.
} 
to establish an Interclub in Linz. ${ }^{148}$ The news induced Walter to form the socalled Danube Committee in April 1931 as a co-ordination body for transnational activities in Germany, Austria, Czechoslovakia and Romania. ${ }^{149} \mathrm{~A}$ few months later, he reported the first promising achievements: Revolutionary trade union opposition groups had been formed in Linz and Vienna, agitation had started among port workers in Romania, and the IS $\mathrm{H}$ considered to establish Interclubs in Bratislava and Vienna. ${ }^{150}$ That in Vienna started its operations in fall 1931, consisting of Bulgarian, Czechoslovakian, German, Hungarian, Romanian and Yugoslavian sections. ${ }^{151}$

\subsection{North America, Latin America, Asia and Australia}

The ambition of the ISH was to become a global player and its first manifesto invited all revolutionary maritime transport workers' unions and opposition groups to affiliate with the new organisation. The 1930 October Hamburg Conference, the starting point of the ISH, raised high hopes for the revitalisation the global outreach of the IPC-TW/IPAC-TW which, at its heydays, had links to opposition groups on all continents apart from Africa. However, the global ambition proved much more difficult and time-consuming to accomplish than the leading comrades had foreseen.

The main obstacle for achieving a global outreach were dysfunctional intercontinental communications or rather their absence. Intra- and transEuropean contacts between Hamburg and the various national sections and Interclubs proved difficult to maintain although the ISH Secretariat had the capacity to intervene by sending instructors to various locations in Europe. On the other hand, the IsH Secretariat had only weak and indirect links to extra-European sections and units. Instead, the ISH Secretariat totally relied on the regional units of the RILU and IPAC-TW in New York, Montevideo, and Vladivostok. As communications with these units were usually slow and irregular, the IsH Secretariat had few if any means at its disposal to intervene lest to direct and monitor activities outside Europe.

Initially, the extra-European units of the ISH constituted of the Marine Workers' Industrial Union (MWIU) in the USA, the Comite Maritimo y Portuario Latino Americana (CMPLA) in Montevideo, and the Pan-Pacific Secretariat of

\footnotetext{
148 ISH, MR January 1931, 534/5/220, 12, RGASPI.

149 Kurze Übersicht der Tätigkeit der Internationale der Seeleute und Hafenarbeiter im Zeitraum vom Oktober 193 o bis April 1931, 12.5.1931, 534/5/221, 73, RGASPI.

150 Walter, Arbeitsbericht der ISH, Hamburg 21.8.1931, 534/5/222, 67, RGASPI.

151 Länderbericht Österreich, in Zweite Plenartagung der Exekutive der ISH, 10-12.9.1931, 534/5/224, RGASPI.
} 
Transport Workers in Vladivostok. However, only the two former ones were officially affiliated with the ISH (see Figure 2), the Pan-Pacific Secretariat of Transport Workers was organisationally never subordinated or even linked to the ISH. The MWIU and the CMPLA, in turn, communicated at times directly with the RILU headquarters and the ISH Sovbureau in Moscow.

An illuminating example of the complex if not complicated relationship between the IsH Secretariat and the extra-European units occurred in 1931 when the IS $H$ headquarters made an effort to intervene in the MWIU. Communications had been patchy and irregular after George Mink's return to the USA in autumn 1930. Distressing news started to reach Hamburg a few months later. Returning German seamen informed the IsH headquarters about chaotic conditions within the MWIU and the Interclubs. The crisis resulted in an intervention of the Trade Union Unity League (TUUL), the US-branch of the RILU, not the ISH, during spring 1931. At the end of the crisis, out of 6,000 MWIU-members only 1,200 remained, and the MWIU was active only in New York, Norfolk and New Orleans. ${ }^{152}$ As a solution to the impasse in the USA, the Is H Secretariat presented a list of radical changes among the MWIU-leadership. Most notably, Harry Hynes was to replace George Mink as president; Mink was to reorganise and lead the Interclub in New Orleans; work was to focus on seamen only and to be concentrated to New York, Chicago, New Orleans and San Francisco. ${ }^{153}$ However, the ISH Secretariat had no means to insure the implementation of its instructions. ${ }^{154}$

Monitoring activities in Latin America also proved unrealistic. Walter planned to strengthen regional activities and reserved USD 300 to pay for the establishment of an Interclub in Buenos Aires. The sum was to be sent to the CMPLA but no news was received from Montevideo for months. ${ }^{155}$ Walter attempted to contact the CMPLA via the RILU Berlin Bureau and even recommended to move the Montevideo Bureau to Buenos Aires. ${ }^{156}$ Finally, a report

\footnotetext{
152 ISH, Mr December 1930, 534/5/219, 73, RGASPI; ISH, MR February 1931, 534/5/220, 86, RGASPI; Kurze Übersicht der Tätigkeit der Internationale der Seeleute und Hafenarbeiter im Zeitraum vom Oktober 193 o bis April 1931, 12.5.1931, 534/5/221, 72, RGASPI.

153 Adolf [Shelley] to "Werte Genossen," Hamburg 24.11.1931, 534/5/223, 97, RGASPI.

154 Eventually, the CPUSA and the TUUL intervened and nominated Roy Hudson and Harry Hynes as collective leaders of the MWIU; Mink was placed as head of the Interclub in New Orleans (Bericht der ISH, 1.1.-15.2.1932, 534/5/230, 44-45, RGASPI). See further Pedersen, The Communist Party on the American Waterfront, $36-48$.

155 ISH, Mr November 1930, 534/5/219, 46, RGASPI; ISH, MR December 1930, 534/5/219, 73, RGASPI.

156 ISH, MR January 1931, 534/5/220, 11, RGASPI; ISH, MR February 1931, 534/5/220, 85, RGASPI.
} 
from the CMP LA reached Hamburg in April 1931. The comrades in Montevideo assured him that they did their utmost to popularise the decisions of the 1930 October Hamburg Conference. However, the plans for opening an Interclub in Buenos Aires proved illusory. ${ }^{157}$

The ambitions to intervene or instruct the comrades in Montevideo were impossible as long as the ISH Secretariat lacked technical personnel fluent in Spanish (or Portuguese). Consequently, and much to the dismay of the comrades at the ISH headquarters, the ISH reported about sections existing in Argentina, Uruguay, and Paraguay but it had no direct links to them. In fact, a Resolution by the RILU on the activities of ISH, the RILU June 1931 Resolution, see further Section 5.1 in this chapter, clearly indicates that the ISH Secretariat had not managed to establish direct contacts with any union or opposition group in Latin America and the Caribbean by mid-1931. Somewhat unrealistically, the Resolution instructed the ISH Secretariat "to give broad and systematic assistance" to the CMPLA and its affiliated organisations in Brazil, Chile, Colombia, Paraguay, Peru, and Uruguay. Further, it ordered the Is H Executive Committee to "set up close connections with the revolutionary class organisations of seamen and dockers, in particular with the Federation of Seamen of Uruguay, the Calao Seamen's Union (Peru), and like wise [sic] with the Paraguayan Seamen's League." Similarly, Moscow expected the ISH Secretariat to get in contact with organisations "not yet affiliated" to the CMPLA. In addition, the RILU impelled the ISH Secretariat to "systematically maintain connections with the Carribean [sic] sub-committee of the fraternal Latin American Trade Union Confederation" and to establish contacts with "countries belonging or closely situated to the Caribbean zone."158

A special target group were maritime transport workers in the British Caribbean. Interestingly, the thrust into the Caribbean was raised by the ECCI Eastern Secretariat already in February 1931. In its instruction to the Central American Bureau, the CPUSA and the All-America Anti-Imperialist League of work in the British Caribbean, the ECCI Eastern Secretariat identified the maritime transport workers as the "leading section of the West Indian proletariat." Agitation and propaganda among them had been conducted by the Interclubs in New York and New Orleans, the Instructions noted, although the MWIU, in particular, was urged to put more effort on its engagement, not least

157 ISH, April 1931, 534/5/221, 62, RGASPI.

${ }_{15} 8$ The Situation, The Work and the Tasks of the International of Seamen and Harbour Workers (Resolution on the report of Comrade Hardy and Walter --- the Chairman and General Secretary of the Seamen and Dockers' International), 12.6.1931, 534/5/221, 121-122, RGASPI. 
in establishing contacts and either forming revolutionary unions or establishing revolutionary groups within the unions in the British Caribbean islands. Once such groups had been formed, the MWIU together with the RILU SubCommittee for Caribbean Countries in New York and the ITUCNW, should render assistance in the formation of a West Indian Marine Workers' Union. In order to achieve this objective, the ECCI Eastern Secretariat proposed the opening of an Interclub "in a leading port."159 Interestingly, the Instructions made no reference to the ISH Secretariat. On the other hand, the MwIU figured as this point as the "American Bureau" of the ISH, especially in its outreach to the Caribbean. Nevertheless, the EcCI Political Commission charged the Eastern Secretariat to discuss the location of the envisioned Interclub in the British Caribbean with the RILU Secretariat. ${ }^{160}$ The deliberations in Moscow, it seems, rendered few results. If there were any concrete plans, the ISH Secretariat were never informed about them. Besides, in its own strategic planning, the ISH Secretariat never identified a port in the British Caribbean for the location of an Interclub.

The only direct extra-European interventions of the IsH Secretariat concerned work among Chinese and Japanese seamen. The ISH Secretariat was in contact with the illegal Japan opposition through telegraph connections to Vladivostok although the PPTUS was in charge of strategic supervision of the Japanese section. Nevertheless, international campaigns in support of the Japanese section were to be directed by the ISH International Secretariat. ${ }^{161}$ Far more ambitious were the plans to boost the activities of the illegal Chinese Seamen's Union. The union, which was an affiliated member of the ISH and listed some 1,00o members, was also monitored through the PPTUs and the Pan-Pacific Secretariat of Transport Workers. The IsH Secretariat, in turn, disseminated the Chinese Seamen's Unions' calls for an international campaign to support the seamen's strike in China. ${ }^{162}$ A "semi-legal" Interclub was established in Shanghai in April 1931 as an attempt to reactive underground activities

159 Draft. Confidential letter, translated from Russian, [ECCi Eastern Secretariat] To the Central American Bureau, CCCPUSA, and the Secretariat of the Anti-Imperialist League. Proposals for the Organisation of Work in the British West Indies, 12.2.1931, 495/4/85, 338, RGASPI.

16o Protokoll Nr 117 der Politischen Kommission des EKKI der Sitzung am 3.2.1931, 495/4/85, RGASPI.

161 [George Hardy] President to Provisional Executive Committee Members, Hamburg 5.2.1931, 534/5/220, 62, RGASPI.

162 ISH, MR December 1930, 534/5/219, 73, RGASPI; ISH, MR January 1931, 534/5/220, 12 , RGASPI. 
in China. ${ }^{163}$ However, the main target of the ISH Secretariat were Chinese seamen residing in European ports, see further Section 4.4 in this chapter.

Direct connections with the two ISH sections in the Far East were of strategic importance, not least from Moscow's perspective. The Chinese section "must do everything to intensify activities on the coasting [sic] ships, which are of great importance in transporting munition against Soviet districts," the RILU resolution stressed. In addition, the Japanese (illegal) section was to strengthen the revolutionary trade union opposition among the seamen as well as "take all necessary measures to penetrate into the masses of dock workers." However, the role of the ISH Secretariat remains unclear in the Resolution, apart from being impelled to "set up firm connections" with its organisations in China and Japan. ${ }^{164}$

Similar weak links existed with the opposition in the Seamen's Union of Australia. Nevertheless, connections had been established by April 1931 and the opposition was listed as a "sympathising" member of the ISH. In practice, the ISH Secretariat had no capacity to influence the opposition or to supervise activities at the Sydney Interclub. ${ }^{165}$ Interestingly, the RILU Resolution did not instruct the ISH to intensify its connections to Australia.

One of the prime target groups of the national sections of the ISH were colonial seamen. Already the October 1930 Resolution of the ISH underscored the ambition of "uniting workers of imperialist, colonial and semi-colonial countries under one revolutionary banner." Colonial mariners, the Resolution emphasised, were exploited and robbed of their elementary rights. The shipowners as well as the "social fascist and fascist" union leaders, in turn, were accused to promote chauvinist tendencies and race hatred among white maritime transport workers. ${ }^{166}$ The objective of the IsH was to fight against chauvinism, exploitation, racism and segregation, its task to emerge as the

\footnotetext{
163 ISH, MR February 1931, 534/5/220, 87, RGASPI; ISH, Half-Year Report October 1930-April 1931, 534/5/221, 74, RGASPI.

164 The Situation, The Work and the Tasks of the International of Seamen and Harbour Workers (Resolution on the report of Comrade Hardy and Walter --- the Chairman and General Secretary of the Seamen and Dockers' International), 12.6.1931, 534/5/221, 122, RGASPI.

165 ISH, Half-Year Report October 1930-April 1931, 534/5/221, 74, RGASPI.

166 Resolution adopted by the International Conference of Seamen and Dockers, held at Hamburg, October 3rd, in Hardy, A Fighting International of Marine Workers, 29.
} 
champion of the oppressed colonial maritime transport workers and to support them to develop their unions in every country. "Economic, political and social equality will be its central slogan in defending and organising coloured and colonial seamen," declared George Hardy. 167

The British and the French sections were especially to focus on black seamen. This was in tandem with the instructions the ECCI sent to the CPGB and PCF in August 1930. ${ }^{168}$ The Minority Movement, the instructions stressed, was to organise black seamen in Cardiff, Liverpool and South Shields. ${ }^{169}$ The C GTU, in turn, was to intensify its work among black maritime transport workers, and to establish separate black unions or locals in Bordeaux and Marseille. The Port Bureaus in France were ordered to take responsibility for agitation and propaganda work among black mariners instead of leaving it in the hands of the LDRN, as hitherto had been the case. ${ }^{170}$ However, as previously noted and will be discussed further below, work among colonial, especially black, seamen remained weak and the parties and revolutionary trade union opposition were slow in targeting them. As a reaction to this, the ISH Secretariat published in 1931 its guidelines for work among colonial seamen, termed Resolution on the Colonial Work of the Sections of the I.S.H. in the Capitalist Counties (hereafter Is H Colonial Resolution) to which all national sections had to commit themselves. The tenor of the guidelines was radical: All IsH sections as well as the revolutionary trade union opposition groups were to adhere to strict colourblindness and open their ranks to non-white members.

The drafting and redrafting of the Is $\mathrm{H}$ Colonial Resolution was a protracted affair. George Hardy opened the discussion in January 1931, and proposed the formation of branches for colonial seamen within the ISH sections unless there already existed national unions in the home countries of the colonial seamen, such as China and India. Existing extra-territorial units of the Chinese and Indian seamen, he proposed, were to become branches of their respective unions. The critical point was Hardy's suggestion of establishing special

\footnotetext{
167 Hardy, A Fighting International of Marine Workers, 26.

168 Protokoll Nr 77 der Politischen Kommission des EKKI der Sitzung am 23.8.1930, 495/4/47, RGASPI.

169 (Draft) Confidential letter to the CPGB, 16.8.1930, enclosed in Protokoll Nr 77 der Politischen Kommission des EKKI der Sitzung am 23.8.1930, 495/4/47, 2O-23, RGASPI. This letter echoes an earlier one sent by the 'Negro Bureau' and the Anglo-American Secretariat of the Comintern in March 1929, calling the attention of the British Party to focus on work among black seamen, see further Weiss, Framing a Radical African Atlantic, 15 o.

170 (Draft) Confidential letter to the CC of the CPF, 22.8.1930, enclosed in Protokoll Nr 77 der Politischen Kommission des EKKI der Sitzung am 23.8.1930, 495/4/47, 28-33, RGASPI.
} 
branches of colonial seamen within the national revolutionary trade union opposition:

Where no colonial union exists, then colonial seamen must be organised into a branch of the revolutionary union in the imperialist country, after which, and when sufficient members exist to warrant it, a national union of these colonial seamen can be organised with headquarters in their own countries, if possible (for instance West Africans). The branches of colonial unions must work always according to the policy of their own union, but also as an integral part of the union in the imperialist countries. This should ensure close cooperation, although language will be a barrier as well as economic and social conditions, making it necessary to hold separate meetings, with an exchange of delegates, etc. When special political meetings are being discussed, they must, of course, be joint meetings with interpreters. Joint discussions over special claims can be had such compensation for crippled colonial seamen's claims for unpaid money, victimisation, etc. ${ }^{171}$

Liao Chengzhi and James W. Ford, the two organisers of work among colonial seamen by the Hamburg Interclub, supported Hardy's idea and he commissioned them to redraft his original text for the guidelines in January 1931 (see below, Section 4.4). ${ }^{172}$ Ford had arrived in Hamburg on 16 November 1930, officially as secretary of the International Trade Union Committee of Negro Worker which headquarters was located at 8 Rothesoodstrasse on the second floor above the Interclub, next to Albert Walter's office. Following Moscow's instructions, Ford was to assist the ISH Secretariat and the Hamburg Interclub in their "special work" among black seamen. ${ }^{173}$

Practical work among colonial seamen was slow to take off in Europe. Shelley and Walter remarked in June 1931 that the missing guidelines greatly hampered activities on how to organised colonial mariners who sailed on ships with a European flag; seemingly, Hardy's proposal had only been discussed among an inner circle in Hamburg and Moscow. Shelley and Walter backed Hardy's idea, and argued for identifying the ship as a 'floating factory' and for organising the

171 George [Hardy] to Alexander, 20.1.1931, 534/5/220, 15, RGASPI.

172 Leo [Liao Chenghzi] and [James W.] Ford, Plan of Work Outlined For the Seamen's International Amongst Colonial Workers. Immediate Tasks, no date [filed 28.2.1931], 534/ 5/220, 82, RGASPI.

173 Duties and Tasks of [ISH] Secretariat Members, (undated), filed 17.3.1931, 534/5/220, 128 129, RGASPI. 
colonial seamen within the national revolutionary trade union opposition of the vessel's flag. On the other hand, they also claimed that such 'organisational principles' were difficult to carry out due to the "Rückständigkeit" (political 'immaturity') of the colonial seamen. Therefore, they proposed that a) Chinese seamen were to be organised as groups affiliated to the Chinese Seamen's Union but at the same time be part of a so-called ship group, for example, the group of the Einheitsverband on a German vessel or the SMM of a British ship. In addition, branches of the Chinese Seamen's Union were to be set up in European ports (indicating, that this process had not yet started). Further, b) the Indian seamen were to be organised through the Indian Seamen's Union in London; the association was to be transformed into the European Secretariat of the Indian red seamen's union as soon as such a union had been established in India. Last but not least, c) the black seamen were to be organised through the European national unions, namely black French colonial subjects within the FUMP, black British colonial subjects residing in Britain within the SMM, and black mariners sailing on German vessels within the Einheitsverband. ${ }^{174}$

The call for a radical, anti-discriminatory, anti-racist and anti-segregationist approach was also raised in the RILU June 1931 Resolution. Although the idea of establishing branches of colonial national unions, in particular Chinese and Indian, in Europe was not a new one, these had been slow in materialising. Even less had been achieved in opening the European national unions for colonial mariners - white chauvinism and overt racism effectively blocked membership of non-whites. The Resolution, therefore, impelled the ISH to wage a "determined fight" against the "opportunist ignoring of activities among coloured seamen" on part of the European sections of the ISH. Furthermore, it prompted the ISH and its European sections to pursue an "insistent fight" against the manifestations of white chauvinism among its own rank-and-file members, not least in denying the application of the slogan of "equal pay for equal work" to coloured seamen. Moreover, the Resolution urged the ISH to pay serious attention to the organisations of black seamen, "who are the worstpaid, the most oppressed section of the transport workers. A determined fight must be waged against race prejudices and the slightest attempts to maintain the race bar or passivity towards same." Although the Resolution text did not specifically address Hardy's idea of forming colonial branches within the (European) national revolutionary trade union oppositions, the reference to the fight against discrimination, racism and segregation within the unions

174 AW, Arbeitsbericht des Sekretartiats der I.S.H., Hamburg 16.6.1931, 534/5/221, 183-184, RGASPI. 
echoes such a proposition. Not least as the Resolution impelled the ISH to become "the militant organisation of seamen and dockers of all countries, races, and continents." ${ }^{175}$ However, the binding guidelines for the sections of the ISH - the ISH Colonial Resolution - were still in preparation ...

\subsection{The ISH Colonial Resolution}

The ISH Colonial Resolution served as the guidelines for agitation and propaganda work among colonial seamen by the ISH Secretariat and its national sections. Ford's and Liao Chenghzi's draft version of the text was adopted by the ISH Secretariat in May 1931. ${ }^{176}$ At this point, the ISH Secretariat planned to translate the text into Indian and Chinese language(s). ${ }^{177}$ The ISH Executive Committee discussed the guidelines at its plenary session in September 1931 but did not approve of them as Shelley criticised the text for not specifying the concrete tasks of the various national sections of the ISH. Shelley decided to draft a third version of the text and sent it to the RILU Secretariat in Moscow for comments in late 1931. The Is H World Congress, in turn, adopted Shelley's redrafted version of the guidelines, i.e., the IsH Colonial Resolution, in May $1932 .{ }^{178}$

According to the ISH Colonial Resolution, the capitalist class was splitting the workers' ranks globally and nationally and prevented national and international solidarity. It further attacked the trade union bureaucracy for assisting the shipping industry and its owners for assisting in the exploitation of the colonial masses and in preparing war against the revolutionary working class and the Soviet Union. "This is especially the case in the shipping industry,"

175 The Situation, The Work and the Tasks of the International of Seamen and Harbour Workers (Resolution on the report of Comrade Hardy and Walter --- the Chairman and General Secretary of the Seamen and Dockers' International), 12.6.1931, 534/5/221, 122, RGASPI.

176 Resolution on the Colonial Work of the Sections of the I.S.H. in the Imperialist Countries, no date [type-written copy, ca. May 1931], 534/5/222, 140-144, RGASPI. The text is identical to I.S.H. Organise Colonial Seamen, copy of printed version of resolution, 534/5/221, $65^{-}$ 67 , RGASPI. I have not yet been able to identify which magazine or journal that published the printed version.

177 Ford to "Dear Comrades," [Hamburg] 4.5.1931, 534/5/221, 64, RGASPI. Ford asked the Colonial Resolution to be printed in "thousands of copies" in each language. However, it is not known if the text was ever translated and printed.

178 Adolf [Shelley] to "Werte Genossen," Hamburg 24.11.1931, 534/5/223, 86, RGASPI. For a full text, see Resolution on the situation and struggles of the seamen and harbour workers in the colonial and semi-colonial countries and the tasks of the sections of the ISH, in: The World Unity Congress of the International Water Transport Workers and it's Decisions (Hamburg: International of Seamen and Harbour Workers, no date [ca. 1932]), 16-19. 
the Is H Colonial Resolution argued, and further attacked trade union officials for assisting the shipping industry to obtain crews of a specific nationality at wages less than national rates, while at the same time fostering race, colour and religious prejudices, and acting as agent provocateurs and spies of the shipowners. The national sections of the ISH, on the other hand, were ordered to reject all forms of race prejudices and white chauvinism as well as to counteract the splitting tactics of the shipowners and "Social Fascist and Fascist trade union officials." ${ }^{179}$

The ITF was the main target of the verbal onslaught of the ISH Colonial Resolution, being accused of splitting the ranks of the maritime workers throughout the world and blocking the fight for colonial independence. The ISH Colonial Resolution, therefore, urged the national sections of the ISH to organise the colonial seamen into a "militant class union." Ultimately, the ISH Colonial Resolution called for the enrolment of colonial and "coloured" seamen "on the basis of absolute equality in every respect with the seamen of imperialist countries" and to elect colonial seamen as members of ship committees. ${ }^{180}$

Most important, however, was the need to establish branches of "militant class unions of colonial and semicolonial countries" in the ports of the imperialist countries, i.e., local branches of black, Indian, Chinese and other national seamen's unions. The key idea was to establish transnational networks of colonial/semicolonial seamen's unions linked to the national seamen's unions in Europe. In praxis, these local extraterritorial colonial/semi-colonial branches were to be linked to the national headquarters in a respective country where such unions existed, notably Belgium, Britain, France, the Netherlands, and the USA. "Unity of action" was the guideline. The colonial/semicolonial branches were to cooperate with the national unions although "while collectively working under jurisdiction of the district or national organs, they shall carry out the political line of the union of their native country in order to ensure the greatest possible assistance in the general struggle against imperialism and their native oppressors, and to enhance the struggle for complete national independence."181

The ISH Colonial Resolution further instructed its sections to develop cadres for organising African and other colonial seamen. Of equal importance was the need to enlighten the membership of the national unions in the imperialist countries about exploitation of non-white seamen and their everyday struggle

\footnotetext{
179 Resolution on the Colonial Work of the Sections of the I.S.H. in the Capitalist Counties (hereafter: ISH Colonial Resolution), 495/25/1334, 1-2, RGASPI.

18 o ISH Colonial Resolution, $2-3$.

181 ISH Colonial Resolution, 3-4.
} 
against racism and white chauvinism. In addition, efforts were to be made to establish organisations of colonial seamen in a port where no militant class organisation existed. These branches were to be under the control of the IS $\mathrm{H}$ Secretariat in Hamburg "until a class seamen's organisation is formed in the particular port."182

\subsection{Brothers in Arms? The ITUCNW and the ISH}

The intimate structural connections between the ISH and the International Trade Union Committee of Negro Workers (ITUCNW) were part of the grand strategy designed in Moscow. The reorganisation of the IS H Secretariat in midDecember 1930 framed the close relationship between the ITUCNW and the IS H. Hardy instructed Ford to participate at the meetings of the IS H Secretariat and encouraged him to agitate among seamen. The ISH Secretariat, in turn, promised to assist him in his work. Nevertheless, Hardy recognised that Ford's public engagement could endanger his activities in Hamburg: "For him to become a constant visitor to the ships, increased dangers would arise from his attendance at the Secretariat meetings." In addition, Ford's obligation to edit the ITUCNW-journal was time-consuming and restricted his capacity to attend the meetings of the ISH and the Interclub. ${ }^{183}$

Ford's main propaganda tool was The International Negro Workers' Review, the mouthpiece of the ITUCNW. Edited by him, and renamed in March 1931 as The Negro Worker, it was sent by post to those countries were communist and anti-colonial agitation was legal (such as the USA and the United Kingdom). However, British and other colonial governments were quick to banish its circulation in the Caribbean and in sub-Saharan Africa. This posed few problems for Ford as the journal was illegally stowed on board ships and distributed by seamen when reaching a port. ${ }^{184}$

The tenor of the ITUCNW-journal was in tune with the general strategic considerations of the ISH leadership of organising the black mariners via the sections of the ISH. Ford even publicly stated in an article in The Negro Worker that black seamen primarily were to join the ISH rather than the ITUCNW as the latter was not a trade union organisation per se:

Negro seamen in their travels and experiences must establish contact and connection with the international revolutionary workers' movement, and in the first place, join and help build the International of Seamen and

182 ISH Colonial Resolution, 4-5.

183 George [Hardy] to "Alexander," Hamburg 15.3.1931, 534/5/220, 117, RGASPI.

184 Weiss, Framing a Radical African Atlantic, 341-342. 
Harbour Workers, fight to better their own conditions and in the same timer to bring the principles of the international revolutionary workers' movement to their brothers in Africa. ${ }^{185}$

This position was further underlined in an English bulletin of the ISH that Ford had helped to edit, titled Concrete Work Among Negro Seamen During the Last Period. ${ }^{186}$

The ITUCNW organ became the main propaganda tool for the ISH in its outreach to black seamen. Early in 1931, The International Negro Workers' Review informed its readers about the struggles of the German harbour workers in Hamburg against intended wage cuts. In Britain and Japan, the journal informed, shipowners were planning an attack against seamen and harbour workers. The leaders and bureaucrats of the national unions of maritime transport workers, branded as 'social fascist', were accused to betray the workers by siding with the capitalist owners and by backing the reduction of wages and splitting the maritime working-class. This was no surprise, the journal reminded its readers: The reformist and 'social fascist' trade union bosses had "always betrayed the Negro and 'coloured' seamen." However, a new era of radical international solidarity among the maritime workers had started with the establishment of the ISH, the journal assured. This organisation, the journal heralded, was the only one that was prepared to fight back against wage cuts and the reduction of living conditions on board, "for equal pay and equal conditions, for the complete equality of the workers of all races." The announcement ended in calling the black seamen and harbour workers throughout the world to join in the united front with the Hamburg harbour workers and, even more important, to enlist in the militant sections of the International of Seamen and Harbour Workers: "UNITE IN INTERNATIONAL SOLIDARITY! STRUGGLE AGAINST IMPERIALIST WAR!"187

The Negro Worker carried a similar but much longer call for radical international solidarity among maritime workers in July 1931, addressing two main points. First, the struggle against the 'imperialist war', i.e., the campaign against the (presumed) 'imperialist' plan to attack against the Soviet Union, was part of the daily struggle of the maritime transport workers for bettering their

\footnotetext{
185 James W. Ford, "Negro Seamen and the Revolutionary Movement in Africa - Some lessons from Chinese seamen", The Negro Worker 1, no. 4-5 (April-May 1931): 10.

186 Ford to Padmore and the RILU Secretariat, [Hamburg] 6.8.1931, 534/3/668, 109, RGASPI. Unfortunately, I have not found any traces of the bulletin.

187 NN, "Negro Seamen and the German Harbour Workers," The International Negro Workers' Review 1, no. 1 (January 1931): 5 .
} 
conditions on ships, in ports and in the transport industry. Second, the most exploited ones on board as well as ashore were the colonial seamen: "They are nothing but slaves to the ship-owners." Trade unions affiliated to the International Federation of Trade Unions and the ITF were branded as lackeys of the capitalist owners and "storm brigades and war inciters against the Soviet Union", backing the exploitation of colonial workers and propagating race hatred between black and white maritime workers. The ISH, in contrast, was the only organisation that adhered to proletarian international solidarity among black and white maritime workers. ${ }^{188}$

Although the author of the two calls to the "Negro" seamen is not stated, it is evident that the ISH used the journal of the ITUCNW as a propaganda tool and someone at the ISH headquarters had drafted the texts. A textual analysis of the articles and notes published in The Negro Worker clearly indicates that the two calls differed in style and language and resembled those of the ISH. ${ }^{189}$

\subsection{Work among Colonial Seamen in Hamburg: Promises and Pitfalls}

Work among colonial seamen in Hamburg had since 1929 been restricted to Chinese crews and was carried out by Liao Chenghzi who worked as a special functionary at the Interclub (see further Chapter 4.2.4). Liao Chenghzi's efforts slowly paid off and in early 1931, he had established an organised and wellfunctioning group of radical Chinese seamen in Hamburg. ${ }^{190}$ A few months later, he managed to set up a similar group in Rotterdam. ${ }^{191}$ Impressed by his achievements, and to further boost work among Chinese seamen in Europe, the ISH Secretariat decided in May 1931 to establish a West European Secretariat for the Chinese Seamen's Union. Most likely headed by Liao Chenghzi, it was to set up branches of the Chinese Seamen's Union in Belgium, England, and France as well as monitor the activities of those already existing in Germany (Hamburg) and the Netherlands (Rotterdam). ${ }^{192}$

Work among other colonial seamen in Hamburg was weak. In part, this was due to few of them visiting the Interclub but the main problem was the lack of foreign (non-white) functionaries. ${ }^{193}$ In January 1931, however, Liao Chenghzi

\footnotetext{
188 NN, "August First and the Negro Toilers," The Negro Worker 1, no. 7 (July1931): 4-6 (quotation from page 6).

189 See further Weiss, Framing a Radical African Atlantic, 320-323.

190 ISH, MR January 1931, 534/5/220, 12, RGASPI.

191 ISH, MR April 534/5/221, 63, RGASPI; RGASPI; ISH, Half-Year Report October 1930-April 1931, 534/5/221, 74, RGASPI.

192 AW, Arbeitsbericht des Sekretartiats der I.S.H., Hamburg 16.6.1931, 534/5/221, 177, RGASPI.

193 Monthly Report of the Hamburg Interclub for June 1930, 534/5/216, 38-39, RGASPI. According to Robbie Aitken and Eve Rosenhaft, an unspecified number of Africans were
} 
started to co-operate with James W. Ford and they established the colonial section at the Interclub. Following George Hardy's proposal, they outlined a double strategy for work among colonial seamen. Chinese and Indian seamen, on the one hand, were to be informed about the extra-territorial branches of their national unions and the revolutionary trade union opposition groups within the (European) unions. Black seamen from Africa and the Caribbean, on the other hand, were to be utilised "to develop work in their country." In addition, the local Interclubs in Rotterdam and Marseille were to focus on black, Indonesian and Chinese seamen residing in these two ports. ${ }^{194}$

Ford and Liao Chenghzi divided the colonial section of the Hamburg Interclub into three subsections, a Chinese, an Indian ${ }^{195}$ and a 'Negro' one. The outline of the 'Negro Corner' was similar to that of the other Colonial Corners in the Interclub and is the only one of which there exists a description of its setup. The central spot was a map, showing the extent of the "developing struggles of the Negroes in Africa." Further, there was a huge notice board with pictures and cuts from newspapers and magazines about the life and struggles of the African working class terror, life of black workers. "From time to time we enlarge this," Ford explained. ${ }^{196}$ Last, but not least, the Chinese and Indian subsections were commissioned to publish their own respective bulletins. ${ }^{197}$ Walter, at first, was full of praise and hailed the close cooperation between the ISH and the ITUCNW. ${ }^{198}$

living in Hamburg during the 1920s, notably in the working-class districts of St Pauli and Neustadt, and were working in the harbour. However, it is unclear to what extent they visited the Interclub, see Robbie Aitken and Eve Rosenhaft, Black Germany. The Making and Unmaking of a Diaspora Community, 1884-1960 (Cambridge: Cambridge University Press, 2013), 122.

194 Leo [Liao Chenghzi] and Ford, Plan of Work Outlined for the Seamen's International Amongst Colonial Workers. Immediate tasks, no date, filed 28.2.1931, 534/5/220, 77-80, RGASPI; Duties and Task of Secretariat members, 17.3.1931, 534/5/220, 12-19, RGASPI.

195 In his report of April 1931, Ford stated that there was no comrade in charge of the Indian subsection. He had inquired from LAI Secretary Chattopadhyaya in Berlin about helping him solving the problem, and Chattopadhyaya had proposed to send a young Indian student from Frankfurt to Hamburg. At the time of writing his report the issue had not been settled. See Ford, Work among Negro Seamen, report sent to Padmore and the RILU Secretariat, [Hamburg] 30.4.1931, 534/3/669, 145, RGASPI. Hereafter: Ford, April 1931 Report.

196 Ford to Padmore, 6.8.1931, 534/3/668, 104-107, RGASPI.

197 Plan of Work Outlined for the Seamen's International Amongst Colonial Workers. Immediate Tasks, no date [filed 28.2.1931], 534/5/220, 82, RGASPI; Ford, April 1931 Report, 145. Ford did not mention if the Negro Subsection was charged to launch an own bulletin. This, one could argue, was unnecessary as Ford was already publishing The Negro Worker. 198 ISH, MR January 1931, 534/5/220, 10-13, RGASPI. 
Apart from being in charge of the Negro Subsection, Ford was at times engaged in the work of the Anglo-American Section of the Interclub. In addition, he organised a weekly course on the colonial question in the Club. During alternate weeks, special focus was given to the Chinese and 'Negro' Questions as well as to daily political and organisational tasks among seamen from these regions. While the colonial course gathered up to $5^{\circ}$ participants, the course on the 'Negro' Question collected only a handful of listeners. ${ }^{199}$ The Interclub, in turn, organised special courses for training colonial cadres, among others six Chinese comrades who the ISH planned to utilised in Belgian, British, Dutch and French ports. 200

Much to the dismay of Ford, cooperation with Walter and the Is H Secretariat turned out to be rather lukewarm and was not always forthcoming. Already in his first report of activities in Hamburg, Ford made some critical remarks about "subjective factors" that hampered his work in Hamburg. Some members of the ISH were critical about hosting a suspicious black organisation at Rothesoodstrasse, as they feared the ITUCNW to invite the local police authorities to raid and to shut down all activities at the Interclub. In addition, the promised technical assistance by the ISH Secretariat and the RGO was not forthcoming - Ford had to handwrite his letters as he had no access to a typing machine and the secretaries of the ISH were always "busy."201

Ford's grievances about his troubles in Hamburg must have reached the RILU headquarters as RILU General Secretary Lozovsky criticised Hardy for having erected a "Chinese Wall" between the ISH Secretariat and Ford. Hardy promptly rejected the accusations: "I assure you there is no Chinese wall existing;" Ford had been invited by him to join the weekly meetings of the secretariat and accompany them on their tours to the harbour but Ford himself had informed Hardy and Walter "that he is too busy to attend all the meetings." 202

Nevertheless, Ford's working conditions in Hamburg did not improve. In April 1931, Ford complained about the negative attitude of comrade Krause who was in charge of the Interclub in Hamburg. The atmosphere at the Interclub seemed to have improved after Ford aired his grievances at a joint meeting

199 Ford to Padmore and the RILU Secretariat, [Hamburg] 6.8.1931, 534/3/668, 108, RGASPI. The plans for the colonial courses were already outlined in his April report, see Ford, April 1931 Report, 534/3/669, 145, RGASPI. In this report, he also stated that he and his group had started to outline plans of colonial work for the English, French and Dutch sections of the ISH.

200 ISH, MR September-October 1931, 534/5/223, 22, RGASPI.

201 Ford, January 1931 Report, 534/3/669, 99-100, RGASPI; Adi, Pan-Africanism and Communism, 135 .

202 George [Hardy] to Alexander, Hamburg 15·3.1931, 534/5/220, 117, RGASPI. 
with the ISH and party leadership where it was decided to replace Krause with another comrade (this was perhaps linked to the quarrel between Hardy and Walter, see Section 2.2 in this chapter). Nevertheless, the attitude of Walter remained problematic: "I must say that it is necessary for comrade Walters himself to take a different attitude to the colonial work. I demand that the comrade Walters give me the support in my work that my responsibility to the Executive of the RILU demands." ${ }^{203}$ A meeting with Walter and Hardy was called to discuss the differences in their conception of colonial work. Ford had the impression that while Hardy was in favour of colonial and 'Negro' work, Walter was not. In Ford's opinion, Walter did not give any assistance to his work but was negative about any of Ford's initiatives. Between the lines, Ford even hinted that Walter had a racist attitude towards him:

He has always said that you cannot get colonial workers to come to the Club, but my work here during the last month has clearly and disagreeably disproved this statement. Of course the excuse is that I am a Negro and have a better approach, this is true to a certain extent, but I contend that if the leadership of the Club would take the proper interest and give the proper support we can get white comrades to help in this work. ${ }^{204}$

Consequently, in Ford's mind Walter was nothing but an opportunist. Ford claimed that Walter was afraid that if too many colonial seamen were drawn to the Interclub the police would close it. Even worse, Ford realised that much of the material that the ITUCNW had produced during the last year had never been distributed but was stored at the Interclub. ${ }^{205}$ Walter, on the other hand, critically replied to Ford that it was much easier for a 'coloured' comrade ("farbiger Genosse") to invite the 'coloured' seamen to the Interclub than it was for a white one - implying that it was Ford's task to work among 'coloured' seamen which he had neglected. ${ }^{206}$ Whether or not this was true is unclear as Ford's report for April 1930 stated that the number of 'coloured' seamen visiting the Interclub was increasing, especially those from Africa. ${ }^{207}$

However, the main drawback for Ford's work was Hamburg's peripheral position as a hub for black seamen. On average only about four to six ships that had black crew members called at the port each week. In general, the crew

\footnotetext{
203 Ford, April 1931 Report, 534/3/669, 147-148, RGASPI.

204 Ford to Padmore, handwritten date: April 30 [1931], 534/3/668, 72, RGASPI.

205 Ford to Padmore, 30.4.1931, 534/3/668, 72, RGASPI.

206 Protokoll der Sitzung der Parteifraktion der ISH, 30.4.1931, 534/5/220, 45-56, RGASPI.

207 ISH, MR April 1931, 534/5/220, 57-63, RGASPI.
} 
counted between half a dozen and a dozen black seamen and they would stay in Hamburg only for a few days. None of the black seamen Ford had interacted with had residency in Germany. Especially on board English and Dutch vessels, there were no ship cells or revolutionary trade union opposition groups. Despite these constraints, Ford made quite an impact during his ten-month sojourn in Hamburg. By mid-September 1931, he had managed to form cells or at least enlist some individuals on board of twelve British ships: the Dagomba, the Dalcross, the Daru, the Daunkwa, the Deido, the Dixcove, the Ethiopian, the Henry Stanley, the Jonathan C. Holt, the Thomas Holt, the Thornlia, and the William Wilberforce. ${ }^{208}$ Presumably, they all joined the SMM - in accordance to the plan to enlist black seamen in national unions of the flag of their vessel, although Ford did not state this in his report. At least those on the Thomas Holt did so, and Hardy notified sm M Secretary Thompson in London that they were prepared to assist in creating the (projected) British red seamen's union. ${ }^{209}$

\subsection{Agitation among Colonial Mariners in France}

Garan Kouyaté served as the prime agitator and organiser of black and colonial mariners in France. He had started as a special envoy for work among black mariners in Marseille in 1930 and managed in the course of two weeks in drawing 208 of them into the FUMP. He also established so-called "Cultural Committees" on board French vessels, each consisting of three "colonial comrades," and had instructed them to explain to their fellows the contents of "our political and TU revolutionary press." However, membership declined drastically after Kouyaté left Marseille. According to him, this was mainly due to "bureaucratic methods of working" of the Madagascan secretary Adriamanatena and accused him for having failed to organise meetings on the ships, to collect the dues on board the ships, to agitate ashore, and to organise any meetings for colonial seamen at the Interclub. ${ }^{210}$

When Kouyaté returned to Marseille in July 1931, all "colonials" had left the union and he had to start his agitation from scratch. On 12 July, he organised a meeting that was attended by 135 black seamen in addition to "Indo-Chinese and Arabs." The gathering marked the starting point for his assignment as key organiser of the Interclub. A "Colonial Fighting Committee" was elected which included representatives of each colonial group: African ("bambara, ouolof,

208 [Ford,] ITUCNW Report 1930-1931, 534/3/669, 230, RGASPI.

209 (Half-burnt copy of letter) Hardy to Thompson, [Hamburg] 8.4.1931, George Hardy personal file, KV $2 / 1027$, TNA.

$210 \mathrm{G}$ [aran] K[ouyaté], Report on colonial seamen, no date [ca. January/February 1932], 534/ 5/23O, 23, RGASPI. 
soussou, ivorien, comerien, dahomeen, sarankole"), Madagascan, Arab, Somali and Indo-Chinese. Furthermore, he organised a "school" to train trade union cadres. 30 black seamen attended the courses for elementary literacy whereas 12 "comrades" were participated in political and trade union courses. The promising progress was cut short when the police arrested Kouyaté. After his release from prison, Kouyaté energetically resumed his activities on the waterfront in Marseille and by December 1931, the local branch of the FUMP listed 320 members of which "at least" 40 percent were black mariners. In addition, he had established an Unemployment Committee, counting 145 members of which 80 were black seamen. ${ }^{211}$

Kouyaté embarked on a nation-wide agitation tour in November and December 1931, organising meetings and gatherings for black and colonial seamen in Rouen (6o present), Le Havre (8o present), Dunkirk (5o present at the first meeting, 78 at the second), Bordeaux (110 present). Organising black and colonial seamen proved challenging as their previous encounters with communist trade union activists had been a negative one. In Rouen, for example, Kouyaté was told that white seamen working on board the steamer Medja had demanded to live in separate quarters from their black mates. The shipping company first rejected their demand but gave in after the communist trade union organiser Le Minter had backed their demand. Kouyaté urged the communists to adhere to the racial principles of anti-chauvinism and antiracism: "These complaints are of great significance in the struggle against race chauvinism that, unfortunately, is displayed only too frequently by the white seamen on the ships. It gives rise to profound lack of confidence among the colonials to the united front movement."212

Despite the negative experiences of the black and colonial mariners, Kouyaté achieved some notable results in enlisting them in the FUMP. Black and colonial seamen joined local "Vigilance Committees" and participated in strike pickets in Rouen, committees of unemployed black and colonial seamen affiliated to the central (communist-controlled) unemployed committee in Rouen and Bordeaux. Inspired by his success in France, Kouyaté wrote to his contacts in Dakar (Senegal) and Conakry (Dahomey/Benin), and urged them to "speedily consider the possibility of setting up unitary seamen's and docker's unions in these ports." ${ }^{213}$ Reading his report in Hamburg, the comrades at the

211 G[aran] K[ouyaté], Report on colonial seamen, no date [ca. January/February 1932], 534/ 5/230, 24, RGASPI.

212 G[aran] K[ouyaté], Report on colonial seamen, no date [ca. January/February 1932], 534/ 5/230, 19, RGASPI.

213 G[aran] K[ouyaté], Report on colonial seamen, no date [ca. January/February 1932], 534/ 5/230, 19-23, RGASPI. 
IS H Secretariat certainly deemed Kouyaté as their key asset in extending the revolutionary waterfront to French West Africa and beyond.

\subsection{A Potential Connection? The Kroomen's Seamen Club in Freetown}

One of Ford's obligations was to visit ships in the Hamburg harbour and get in touch with black seamen. One of these meetings occurred in mid-April 1930. At this occasion, he was to hear about the existence of a potential radical organisation in West Africa, the Kroomen's Seamen Club in Sierra Leone. Although the club was not a trade union, Ford notified George Padmore, the head of the RILU Negro Bureau, it had put forth demands for better wages, shorter hours, better working conditions and pay for overtime as well as better food on board. The club had been established in 1923 but due to internal rifts and "tribal differences", it had not been able to coordinate its work and had been prevented from unity and concerted action. Two years later, they managed to bring about some unity between the two main ethnic groups in the club. They achieved some of their demands and started to put pressure on the Elder Dempster Shipping Company to be recognised as the representative of the West African seamen. So far, Elder Dempster had refused to acknowledge them and told them that they were first to establish contacts with some trade unions in Europe before they could be recognised as a partner in the negotiations. ${ }^{214}$ The Africans, on the other hand were reluctant to comply with this demand as they regarded the British National Union of Seamen (NUS) of having few sympathies to their cause. ${ }^{215}$

The person whom Ford had met on board introduced himself as a member of the executive committee of the Club, living at the time in Liverpool. ${ }^{216}$ Ford became even more interested in the group when the African seaman disclosed to him that the Club had plans to affiliate with a militant seamen's union. Ford therefore arranged for representatives of the Club to meet with George Hardy,

214 Ford to Padmore, Hamburg 20.4.1931, 534/3/668, 65, RGASPI. Elder Dempster was also criticised for refusing to employ unionised shore workers and seamen. On the constrained relationship between Elder Dempster and West African labour and trade unions during the 1920 and 1930s, see Marika Sherwood, "Elder Dempster and West Africa 1891c.1940: The Genesis of Underdevelopment?," International Journal of African Historical Studies, 30, no. 2 (1997): $265^{-267}$.

215 Sherwood, "Elder Dempster," 266.

216 Hakim Adi suggests that the Sierra Leonean living in Liverpool who met Ford in midApril 1931 was Ebenezer Foster Jones. According to Adi's information, before becoming a seaman, Foster Jones had been employed as a police in Sierra Leone and was one of the leaders of the Kroomen's Seamen's Club. See further Adi, “The Comintern and Black Workers," 234. 
who outlined the programme of the IsH for the black seamen. At another meeting with the Africans, Ford had a long talk with them about the objectives of the ITUCNW, the RILU and the ISH. When Ford wrote his report to Padmore about the Club, the question of affiliating the Kroomen's Seamen Club to the ISH and the ITUCNW was still open - neither Ford nor the Secretariat of the ISH for the time being ready to accept the affiliation of the group as they had little information on the group. Ford regarded the group to be a sort of social club that was typical in West Africa but with the potential to become one of the radical spearheads in West Africa. ${ }^{217}$

However, the Sierra Leonean fellow did not know that the Kroomen's Seamen Club had ceased to exist. Intertribal clashes had split the association into two rivalling fractions, and the shipowners used this situation to play one group against the other. Sometimes in mid-1930, the two groups reached a truce, paving the way for the formation of a new organisation, the United Seamen's Club, located at 3 Krootown Road, Freetown. ${ }^{218}$ At this point, the ISH heralded the new group as a prospective unit in Sierra Leone, and included the club in its list of Interclubs. ${ }^{219}$ However, the comrades in Hamburg must have realised by the end of the year that the United Seamen's Club was never to develop into a revolutionary hub. Consequently, they removed the club from the list of Interclubs. ${ }^{220}$ On the other hand, the plan of establishing a spearhead of the ISH in Freetown or somewhere else in West Africa was to resurface in the years to come.

\subsection{Mobilise Colonial Seamen for August First}

International proletarian solidarity was the catchword of the Communists and its annual manifestation were the rallies and demonstrations organised on August First. For 1931, the ISH Secretariat planned to introduce a new theme to the mobilisations - the united front of colonial and white water transport workers. Instructions were sent in early July to all sections, ordering them to highlight the plight of the exploitation of their colonial "class brothers" and to pay special attention to work among colonial seamen. Echoing the Imperialist War Theses of the Comintern, the ISH sections were to combine in their propaganda the obligation to defend the "Fatherland of oppressed peoples" and

\footnotetext{
217 Ford to Padmore, Hamburg 20.4.1931, 534/3/668, 66, RGASPI.

218 Foster Jones, "Situation of Native Workers in Sierra Leone," The Negro Worker 1: no. 4-5 (April-May 1931): $3-5$.

219 Der Internationale Seemannsklub, 534/5/222, 105-117, RGASPI.

220 The United Seamen's Club was not even mentioned in the joint Is the Negro Seamen and Dockers, 534/5/223, 175-183, RGASPI.
} 
the fight against colonial oppression and suppression of colonial masses. "The campaign against imperialist war danger and intervention in the USSR must be connected with the daily struggles of the transport proletariat for bettering their conditions on ships, in ports and in the transport industry," the Instructions noted. The most down-trodden were the colonial seamen, the ISH Secretariat reminded, who "are threatened with wage cuts, speeded-up and reduced unemployment by undermanning and have the most horrible conditions on the ships." The colonial workers were nothing but "slaves of the shipowners," lowest paid and facing worst working conditions on board. Most importantly, and in tune with the 'Class-Against-Class'-doctrine and IsH's verbal onslaught on the ITF, the ISH trumpeted: "(I)t must be made clear to the colonial seamen that the reformist unions of the Amsterdam International not only pay the role of storm brigades and war inciters against the Soviet Union but do everything in their power to carry out the policies of the bourgeoisie in dividing the ranks of the workers."221

The demonstration of international proletarian solidarity on August First was an utmost priority in 1931, the ISH Secretariat declared. As the shipowners as well as the "reformist" trade union leaders and the IT F were known for utilising colonial seamen against white seamen and white seamen against colonial seamen in economic and other struggles, the sections of the ISH were ordered to invite colonial seamen to meetings on board the ships, ashore in ports and to "fraternal meetings" in the Interclubs. The core idea was to mobilised "the broad masses" of the colonial seamen for the August First demonstrations by drawing them into committees, participating them in drawing up slogans for the colonial seamen. Special bulletins and leaflets addressing the colonial question were to be published. The committees were instructed to address the living conditions and standards of colonial seamen as well as to mobilised colonial and white seamen "for the defense of the 8 Negro boys in Alabama."222

Furthermore, the August First-campaign was to be used as a means to organisationally strengthen the ISH among the colonial seamen. Therefore, the sections and committees were to propagate specific slogans for the colonial seamen in addition to the general slogans issued by the RILU, namely:

Equal pay for equal work - Down with fascism, white terror and lynching - Complete evacuation of imperialist soldiers from the colonial

221 For Work Among Colonial Seamen, [Hamburg] 4.7.1931, 534/5/222, 22-23, RGASPI.

222 For Work Among Colonial Seamen, [Hamburg] 4.7.1931, 534/5/222, 23-24, RGASPI. 


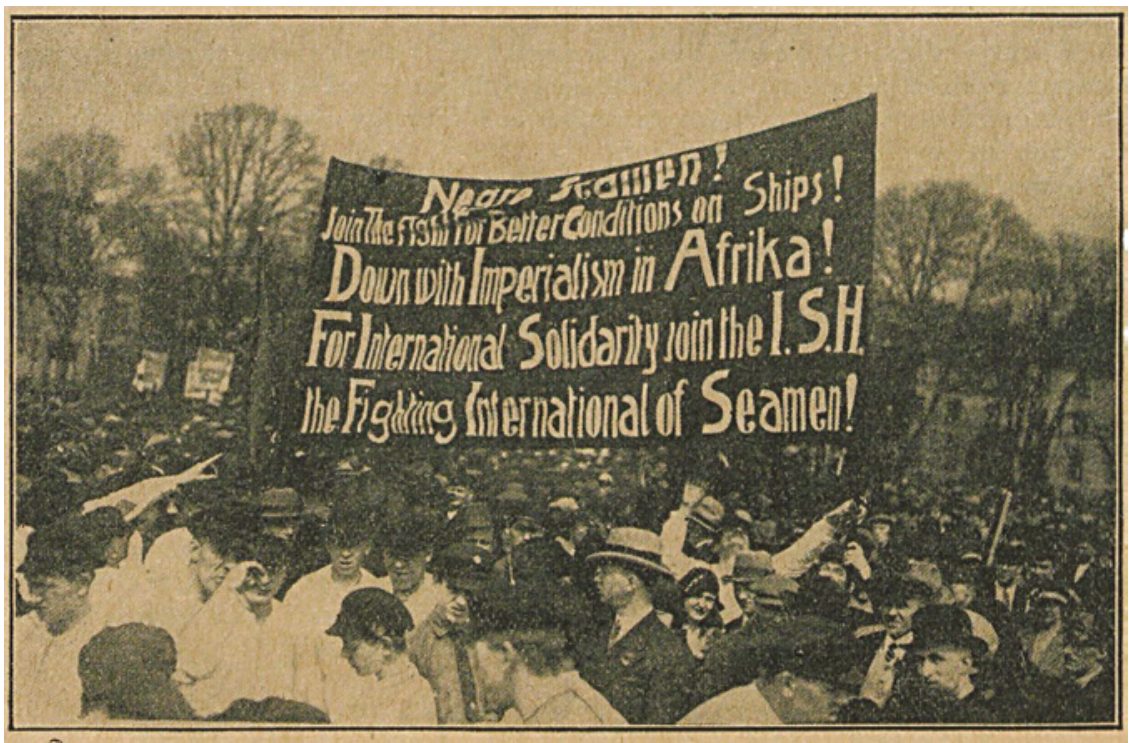

FIGURE 15 Calling black mariners to join the ISH; photograph depicting a rally in Hamburg, published in The Negro Worker, Special Colonial Number 1, no 10/11 (OctoberNovember 1931): 32 . The all-white participants carried a banner with the slogans: "Negro Seamen! Join the Fight for Better Conditions on Ships! Down with Imperialism in Africa! For International Solidarity Join the I.S.H. the Fighting International of Seamen!" Interestingly, the subtitle in The Negro Worker claimed the rally to be "international solidarity with Negro Workers, 100,00o workers demonstrating at Hamburg, Germany, for international solidarity and against imperialism in Africa." However, the slogans on the banner indicate it to be addressed to black seamen and them joining the radical trade union opposition and the ISH.

countries - For complete independence and self-determination - Down with the boarding house masters and serangs - The right of trade unions and assembly in the colonial countries - Long live international solidarity! 223

Whether the August First-campaign turned into a global movement is not known. Ford, at least, published a call in The Negro Worker. At the August Firstmass demonstration, banners urging "Negro seamen" to join the Is H were carried through the streets of Hamburg, see Figure 15.

223 For Work Among Colonial Seamen, [Hamburg] 4·7.1931, 534/5/222, 24, RGASPI. 
Moscow was not impressed by the achievements of the Is H. Expectations had been high in 1930 for rallying the revolutionary trade union opposition behind a new umbrella organisation and attacking the ITF. "Despite the objectively favourable conditions of the development of the mass movement for the immediate economic demands of the seamen, river workers and dockers [...] a decisive improvement has not yet been accomplished in the whole work of the IS H." 224

Rationalisations on board reduced a crew needed to operate a steamer or a motorised vessel. Consequently, the shipping industry introduced wage-cuts and lowered social benefits, leaving an increasing number of the mariners ashore unemployed and jobless. The RILU accused the 'reformist' unions of racist and chauvinist attitudes when barring colonial and 'coloured' seamen to join their ranks as well as demanding that only national, i.e., white organised union members should be hired as crews. Therefore, the RILU underlined the need for a radical bulwark against the unions and the ITF. Although the IsH had witnessed some successes in Germany, Danzig and England, the RILU accused it for having missed several opportunities to mobilise the maritime transport workers, not least by actively engaging and directing national strikes - such as the Norwegian one - and for vigorously pushing the formation of revolutionary trade union oppositions within the national unions. "The fundamental weakness of the IS $\mathrm{H}$ is the absence of live connection with and the instruction of local organisations," the RILU analysts noted. ${ }^{225}$

The most critical point addressed by the RILU was the insufficient organisation of work. "Hardly anywhere is there any systematic work of the formation of revolutionary trade union groups and committees on the ships," the RILU critically observed (and, interestingly, echoing Albert Walter's 'from the bottom'-position). The Is H Secretariat had "insufficient" connections with the sections in the Far East, Latin America and Italy. Further, it had neglected the transformation of the Interclubs into recruitment hubs for new members and facilitators for new ship cells: "Their most important shortcomings consists in the absence of concreteness in the approach to seamen of the various countries, also in the inability of connecting the questions of a general political

224 The Situation, the Work and the Tasks of the International of Seamen and Harbour Workers, [Moscow] 12.6.1931, 534/5/221, 115, RGASPI.

225 The Situation, the Work and the Tasks of the International of Seamen and Harbour Workers, [Moscow] 12.6.1931, 534/5/221, 115, RGASPI. 
nature with those questions which interest and touch the immediate needs of the seamen." 226

Admittedly, the RILU headquarters identified the "insufficient attention" of the leadership of its own national sections as one of most important reasons for the weaknesses and bleak performance of the ISH. ${ }^{227}$ Taken together, the shortcomings were addressed in a resolution in June 1931 that also included new instructions to the ISH. Moscow's harsh criticisms, in turn, prompted the ISH Secretariat to call a meeting of the ISH Executive Committee.

\subsection{The RILU June 1931 Resolution and the ITUCNW}

Moscow's new directives were sent to Hamburg in June 1931. Main emphasis was put on direct action. The ISH Secretariat as well as its sections were obligated to participate in every manifestation expressing the dissatisfaction of the maritime transport workers, to use every opportunity to attack the leadership in the unions, and to expose the preparations for war, i.e., the imperialist attack on the Soviet Union. Key focus was on building up the organisation at grassroots level: "It is necessary to unite the members of the revolutionary trade unions working on one ship and in one particular port, etc., in trade union groups or trade union sections at the place of industry." These local groups were to become the core units in the daily fight against wage reductions, extended working hours, or illegal dismissals of crews. Echoing the earlier instructions of the RILU, the ISH sections and the revolutionary union opposition groups were reminded to turn their attention to the unorganised and colonial seamen; both groups were identified as crucial potential new members for the revolutionary opposition and only through their mobilisation the IsH sections were to emerge as proper mass organisations. ${ }^{228}$

The June 1931 Resolution further highlighted the need to transform the Einheitsverband into a mass movement. Local units were to be established in England and a red seamen's union was to be launched at a national congress at the end of the year. In France, top priority was to organise the harbour workers, whereas illegal activities were to be promoted inside Italy. The Spanish section, in turn, was to link up with the revolutionary organisations in the ports, whereas the MWIU was to focus on black seamen and harbour workers. "The

226 The Situation, the Work and the Tasks of the International of Seamen and Harbour Workers, [Moscow] 12.6.1931, 534/5/221, 116, RGASPI.

227 The Situation, the Work and the Tasks of the International of Seamen and Harbour Workers, [Moscow] 12.6.1931, 534/5/221, 116, RGASPI.

228 The Situation, the Work and the Tasks of the International of Seamen and Harbour Workers, [Moscow] 12.6.1931, 534/5/221, 117-118, RGASPI. 
most important task [...] is the stubborn struggle for the capture of the majority of sailors and dockers who are at present the members of the reformist and other reactionary unions." 229

Likewise, all sections were to devote special attention to recruit the unorganised as well as the unemployed into the red unions or the revolutionary trade union opposition. "By heading the discontent of the widest masses of the unemployed, by organising their struggle for their immediate demands," the ISH and its sections would develop into genuine mass organisation. A cornerstone for the realisation of this objective was the strengthening (i.e., reorganisation) of the Interclubs, their transformation into "real organisational and political centres" and genuine "international clubs [...] of sailors of all nationalities." 230

In addition, the ISH Secretariat was impelled to link up with revolutionary opposition groups in Latin American and the Caribbean, especially those in Argentina, Brazil Cuba, Mexico, Uruguay, Paraguay and Peru. The Asian target groups were the illegal seamen's unions in China and in Japan as well as the (illegal) revolutionary opposition groups among the maritime transport workers' unions in French Indochina, India, Indonesia, the Philippines and Singapore. Finally, an equally urgent task was to intensify work among colonial and 'coloured' seamen in Europe. ${ }^{231}$

The special focus on colonial and 'coloured' seamen was an answer to Ford's earlier critique about the lax attitude of the ISH Secretariat to support his ambition to establish a radical network in the Black Atlantic. Parallel with the ISH directives, the RILU headquarters issued a resolution about the tasks of the ITUCNW and its relationship with the ISH in July $1931 .{ }^{232}$ The sixth paragraph of the list of immediate organisational tasks concerned the relationship between the ITUCNW and the ISH:

6) In view of the insufficient attention paid by the International of Seamen and Harbour Workers to the every-day activities of the Hamburg Committee, likewise the unwillingness of individual leaders of the

229 The Situation, the Work and the Tasks of the International of Seamen and Harbour Workers, [Moscow] 12.6.1931, 534/5/221, 119-121, quote from p. 118, RGASPI.

230 The Situation, the Work and the Tasks of the International of Seamen and Harbour Workers, [Moscow] 12.6.1931, 534/5/221, 118-199, RGASPI.

231 The Situation, the Work and the Tasks of the International of Seamen and Harbour Workers, [Moscow] 12.6.1931, 534/5/221, 121-122, RGASPI.

232 This resolution is referred to as the July 1931 Resolution. However, as with the earlier resolutions, draft version of the resolution text had circulated already in June. 
International Seamen's Club to assist in carrying out mass work, to charge the ISH to ensure systematic assistance in all practical work of the Hamburg Committee. To propose to the leadership of the ISH that they give assistance to the Committee in editing the "Negro Worker". ${ }^{233}$

George Padmore, who headed the RILU Negro Bureau in Moscow, wrote thereafter a letter to Albert Walter, highlighting about the duties of the ISH to cooperate with and to render systematic assistance to Ford and the ITUCNW. He further stressed that Paragraph Six of the Resolution underlined that although the ITUCNW was subordinated to the RILU and its European Bureau, Walter and the other comrades of the ISH Executive were expected, together with Ford, to discuss and decide upon questions that required immediate action. Last, but not least, Padmore ensured that "under your collective leadership the work of the Negro Committee [i.e., the ITUCNW] will be carried out with the fullest results."234

\subsection{The ISH Executive Committee Meeting in September 1931}

The ISH headquarters must have regarded the criticism from Moscow to be at least to some extent unfair. True, the cooperation with Ford had at times been constrained but they had settled their difficulties. Also, as previously noted, the power struggle between Hardy and Walter that had paralysed work at the headquarters in Hamburg during spring - and where, it seems, Ford had unwillingly been part of - had been resolved and the ISH Secretariat was in full operation by June. Although the ISH headquarters had still few means at its disposal to monitor, lest to initiate national strikes, it started to disseminate information about conflicts and strikes, local and national, to its member organisations via its bulletin. The ISH Bulletin, however, was not circulated in public but only to be used by the sections and its functionaries in their respective agitation and propaganda campaigns. ${ }^{235}$ Amongst its first international campaigns, the Is H Secretariat called its sections to organised rallies on August First to protest imperialist rearmaments, ${ }^{236}$ and attached a disposition for a speech on

233 Concrete proposals on Report of Work of Hamburg Committee, 10.6.1931, 534/3/668, 27, RGASPI.

234 Padmore to Walter, [Moscow] 21.7.1931, RGASPI 534/3/668, 96, RGASPI.

235 I have been able to identify a few individual numbers of the German edition of the ISH Bulletin and, so far, none of its English versions for 1931 and 1932. Full series of the $I S H$ Bulletin are not likely to exist due to its limited and "semi-legal" circulation. However, a comparison of the 1933 German and English versions of the bulletin indicates that the issues had the same content.

236 "Der 1. August und der Hoover-Plan," Informationsbulletin der ISH. Deutsche Ausgabe 1, no. 2 (10. Juli 1931): 2-3. 
the World Depression, its impact on the shipping industry and the tasks of the revolutionary opposition for use at meetings. ${ }^{237}$

Colonial work was certainly not of peripheral interest as each issue of the ISH Bulletin informed about the plights and struggles of the colonial seamen although nearly all text published in the June to August issues of the bulletin concerned Chinese seamen. ${ }^{238}$ In addition, the anti-racist and antidiscriminatory commitment was put in the forefront when the ISH Secretariat urged its sections to join the worldwide Scotsboro campaign in defence of nine black boys facing death penalty in the USA. Already the ISH Bulletin of July 1931 noted that the Interclubs in Bremen, Hamburg and the Soviet Union had arranged protest meetings, and the bulletin urged the other sections and Interclubs to join the international campaign. ${ }^{239}$

Nevertheless, the implementation of new RILU directives impelled a systematic assessment of the operational structures of the ISH. The RILU Berlin Bureau, therefore, urged the ISH Secretariat to summon the ISH Executive Committee for a meeting in Hamburg. ${ }^{240}$ Only a few of its members eventually attended the two-day conference in early September 1931, all of them representing European sections: Christensen (Denmark), Koschnik (Germany), Persson (Sweden), Samsing (Norway), Schaap (Holland), Stoeger (Austria) and

237 Rededisposition über DIE INTERNATIONALE KRISE IM WASSERTRANSPORTGEWERBE, attachment to Informationsbulletin der ISH. Deutsche Ausgabe 1, no. 2 (10. Juli 1931).

238 The first issue carried as an attachment a lengthy essay on the exploitation of Chinese seamen at the boarding houses in Amsterdam and Rotterdam, see "Sklavenhandel in Holland," Beilage zum Informations-Bulletin der ISH No 1 - Juni 1931. The second issue informed about successful strikes of Chinese seamen on two French steamers in Hamburg; after the intervention of the IS H Secretariat and the Interclub, the Chinese mates received full salaries, see "Glänzender Kampferfolg chinesischer Seeleute," Informationsbulletin der ISH. Deutsche Ausgabe 1, no. 2 (10. Juli 1931): 4. The next issue informed about another protest of Chinese seamen, "27 chinesische Seeleute geben faschistischem Lloydoffizier proletarische," Informations-Bulletin der ISH. Deutsche Ausgabe 1, no. 3/4 (6. August 1931): 10.

239 "Protestiert gegen die Hinrichtung der acht Negerknaben," Informations-Bulletin der ISH. Deutsche Ausgabe 1, no. 2 (10. Juli 1931): 10. On the international campaign to free the nine 'Scottsboro Boys' who had been sentenced to death by a local court in Alabama, USA, see further James A. Miller, Susan D. Pennybacker, and Eve Rosenhaft, "Mother Ada Wright and the International Campaign to Free the Scottsboro Boys, 1931-1934," The American Historical Review 106, no. 2 (2001): 387-430, Susan D. Pennybacker, From Scottsboro to Munich: Race and Political Culture in 1930s Britain (Princeton, NJ: Princeton University Press, 2009), James A. Miller, Remembering Scottsboro: The Legacy of an Infamous Trial (Princeton, NJ: Princeton University Press, 2009), and Weiss, Framing a Radical African Atlantic, 392-397.

Walter, Arbeitsbericht der ISH, Hamburg 21.8.1931, 534/5/222, 66, RGASPI. 
Thompson (England). An unidentified delegate from Greece joined the conference on the second day. Ford, Liao, Polano, Shelley and Walter represented the ISH Secretariat whereas Pechmann participated as member of the RILU Berlin Bureau. Dumay's, Hardy's and Mink's absence was critically remarked, especially as Hardy initially had responded positively to the invitation while the two others had not even responded to the call. ${ }^{241}$

Six major items were discussed at the conference, the most pressing being the situations of the sections, the reorganisation of the Interclubs, and work among colonial seamen. Most of the delegates indicated that work in the national sections was slowly taking concrete forms. The transformation of the SMM into a red union was debated at length as well as what tactics to be applied by the ISH sections in Denmark, Germany and Norway at the respective forthcoming tariff negotiations. A new militant tactic was to be applied if national strikes occurred: Strike on every national vessel in every port of the world instead of restricting a strike to national ports as hitherto had been the case! $!^{242}$

The need to reorganise the Interclubs resulted in stiff criticism. None apart a few of the German Interclubs had a collective leadership, and only a few Interclubs had functionaries who mastered foreign languages. Consequently, work among foreign seamen had been neglected in most ports. In addition, communications between the Interclubs was sporadic and minimal and the highly acclaimed "socialist competition" had not been introduced at all for enlisting new members to the Interclubs. Persson, Samsing and Thompson complained about the high costs to run an Interclub and the unclear financial obligations of the ISH Secretariat and the sections. Walter, Shelley and Pechmann underlined that while the Interclubs in principle were subordinated to the Is H Secretariat, their operations were to be supported by the sections and the local party organisation. In addition, they stressed, the Interclub as well as the national section should generate their own funds to cover for their expenses. Sarcastic remarks followed when Thompson declared that the Interclubs in the United Kingdom should refrain from launching anti-religious campaigns as the Catholic maritime workers in Liverpool and Glasgow might turn against the Interclubs. Walter replied

241 (Half-burnt copy) Inf. note on ISH and RILU European Secretariat positive response to Hardy attending the plenum of the ISH Executive Committee, no date (ca. August 1931), George Hardy personal file, KV 2/1027, TNA; Leo [Pechmann] to "Werte Genossen," [Berlin] 21.11.1931, 534/4/353, 81, RGASPI.

242 Zweite Plenarsitzung der Exekutive der ISH, 10-12.9.1931, 534/5/224, 1-47, RGASPI; Adolf [Shelley] to "Werte Genossen," Hamburg 24.11.1931, 534/5/223, 84-85, RGASPI. 
that the revolutions could also be ignited on a Sunday, and Pechmann seconded by reminding that one cannot divert anti-religious from ordinary propaganda. ${ }^{243}$

The last item on the agenda was the forthcoming world congress of maritime transport workers, originally scheduled for September 1931. Not surprisingly, the comrades unanimously declared the need to organise it as soon as possible: The World Congress was to officially sanction the establishment of the ISH and elect an ordinary executive committee. After having decided to organised the world congress in May 1932, the conference ended and the delegates left Hamburg. ${ }^{244}$

\subsection{Reorganising Work of the Interclubs}

According to the ISH regulations adopted in 1930, the Interclubs were not part of the national sections but were to be financed and monitored by the ISH Secretariat. The objective with the parallell structure was that the national sections were to focus on agitation within the national maritime unions while the Interclubs were to focus on foreign ships and their crew. ${ }^{245}$ However, the implementation of the rulings proved difficult and Albert Walter drafted new guidelines that were adopted by the ISH Executive Committee at its meeting in September 1931.

Walter's guidelines outlined a clear division of work between the Interclubs and the national sections. In principle, the task of the former was agitation and propaganda among foreign seamen, while the latter units were to concentrate on work among domestic seamen and harbour workers. Walter projected the Interclubs as open spaces that were obliged to welcome not only revolutionary (i.e., communist and militant) seamen but also members of socialist and Christian seamen unions. The cooperation between the Interclub and the national section was of key importance but the guidelines

243 Zweite Plenarsitzung der Exekutive der ISH, 1O-12.9.1931, 534/5/224, 48-82, RGASPI.

244 ISH, Decisions of the II. Plenary Session of the Executive Committee of the ISH on the Activity and Tasks of the International Seamen's Clubs (September 1931), 534/5/224, 202, RGASPI. A summary of the plenum and its decision was published in the ISH Buletin, see "Das 2. Plenum des IsH," as well as the 10-page supplement, "Anhang: Plenum des Exekutiv-Komitees der ISH," Informations-Bulletin der ISH. Deutsche Ausgabe 1, no. 6/7 (28 September 1931).

245 (ISH instructions,) An alle Interclubs und sämtliche angeschlossene Organisationen, 4.4.1931, 534/5/221, 1-4, RGASPI; Resolution über die Tätigkeit des Hamburger Internationalen Klubs, no date, filed 15.IV.1931, 534/5/220, 155-161, RGASPI; Decisions of the II. Plenary Session of the Executive Committee of the ISH on the Activity and Tasks of the International Seamen's Clubs, September 1931, 534/5/224, 191-203, RGASPI. 
underlined that the Interclubs were not to be perceived as nurseries for the national sections. The IsH Executive Committee accepted Walter's plan without revisions. ${ }^{246}$

The guidelines also emphasised the strategic and tactical organisation of the Interclubs. Each of them were to receive membership cards and signs from the national sections. The national section, in turn, was to be informed each time an Interclub enlisted a new member. In case of the new member originating from a country where communist activities were illegal, the ISH Secretariat was to be informed instead. The most important task, however, was the formation of ship cells and ship committees, the action plan reminded. The former ones consisted of mariners who belonged to a revolutionary opposition; the latter one comprised all members of the crew and was led by members of the ship cell. ${ }^{247}$

The operational spaces of an Interclub were both the ships and the harbour area at large. If the functionaries of an Interclub were barred from entering a ship, they were obliged to get in contact with the crews when they whet ashore and strolled on the street or visited bars and seafarer's lodges. The guideline of an Interclub was proletarian international solidarity, banning intra-racial barriers as well as any forms of segregation, white chauvinism and discrimination of non-white visiting seamen. The Interclub was to constitute an attractive 'counter-space' for the foreign seamen by arranging programmes and lectures in various languages as well as to cooperate with local socialist unions and invite their representatives as speakers. On the other hand, they were to confront the Christian seamen's mission by sending agitators to their meetings and impel foreign seamen to visit the Interclub. The Interclub, in turn, was to transmit an anti-religious message: Its walls being coated with banners carrying anti-religious slogans, and anti-religious literature was to be on display in its library. ${ }^{248}$

A key obligation was the fight against the imperialist war (i.e., the anticipated attack on the Soviet Union) as well as the fight against "white terror" (i.e., the clampdowns and suppression of communist activities) and fascism. Part of the fight was to be visual and propagandistic: The interiors and journals of the Interclubs were to carry anti-fascist slogans and caricatures. Of

246 Decisions of the II. Plenary Session of the Executive Committee of the ISH on the Activity and Tasks of the International Seamen's Clubs, September 1931, 534/5/224, RGASPI.

247 Decisions of the II. Plenary Session of the Executive Committee of the ISH on the Activity and Tasks of the International Seamen's Clubs, September 1931, 534/5/224, RGASPI.

248 Decisions of the II. Plenary Session of the Executive Committee of the ISH on the Activity and Tasks of the International Seamen's Clubs, September 1931, 534/5/224, RGASPI. 
equal importance was the establishment of 'surveillance committees' in the harbours; these were to enlist communist and other union members as well as jobless and un-organised seamen and harbour workers. The 'surveillance committees' were to report on the transport of war material and troops and to organised protest meetings and demonstrations. ${ }^{249}$

Each Interclub was to enlist functionaries mastering several languages. They were to visit the ships and be at hand for foreign seamen every day. In addition, the management of an Interclub was to render assistance to foreign seamen and to organised legal help when needed. Most important, however, was Walter's idea of the Interclub as a social space. The premises were to be cleaned every day and should contain a reading room, a library, a writing room with letter-boxes. Miscellaneous activities were to be organised for foreign seamen while visiting a port: Orchestras, theatre clubs, choirs, sport and excursions. Operational planning was to be conducted by a collective leadership of an Interclub, including the club secretary, a seaman, a harbour worker and representatives for the foreign national sections. Practical day-to-day work was to be carried out by the so-called 'club active' composited of local and foreign mariners. ${ }^{250}$

Inter- and transnational cooperation was another catchword in Walter's guidelines. The leadership of the Interclubs were envisioned to be in constant contact with each other and to challenge each other by arranging 'revolutionary competitions'. Communications between the various Interclubs had been poor hitherto, and Walter's idea was to entrust some of the larger Interclubs to monitor activities in lesser ones (see Map 2). The Hamburg Interclub was to supervise activities of the Interclub in Danzig; the latter club was to establish English, Estonian, Finnish, French, Latvian, and Scandinavian sections as well as to focus on agitation among Polish seamen. The Archangelsk, Hamburg, and Leningrad Interclubs were to monitor the Scandinavian Interclubs; their special target, in turn, were Baltic, Finnish and Polish mariners. The Interclub in Marseille was to concentrate on Greek, Italian, Spanish, and Yugoslavian vessels and Walter instructed it to open an Interclub in Oran. The special target of the Amsterdam and Rotterdam Interclubs were crews on Belgian, Dutch, French, German, and Swiss river steamers. The Interclub in Piraeus was to be monitored by the Marseille and Odessa Interclubs and to focus on

249 Decisions of the II. Plenary Session of the Executive Committee of the ISH on the Activity and Tasks of the International Seamen's Clubs, September 1931, 534/5/224, RGASPI.

25 O Decisions of the II. Plenary Session of the Executive Committee of the ISH on the Activity and Tasks of the International Seamen's Clubs, September 1931, 534/5/224, RGASPI. 


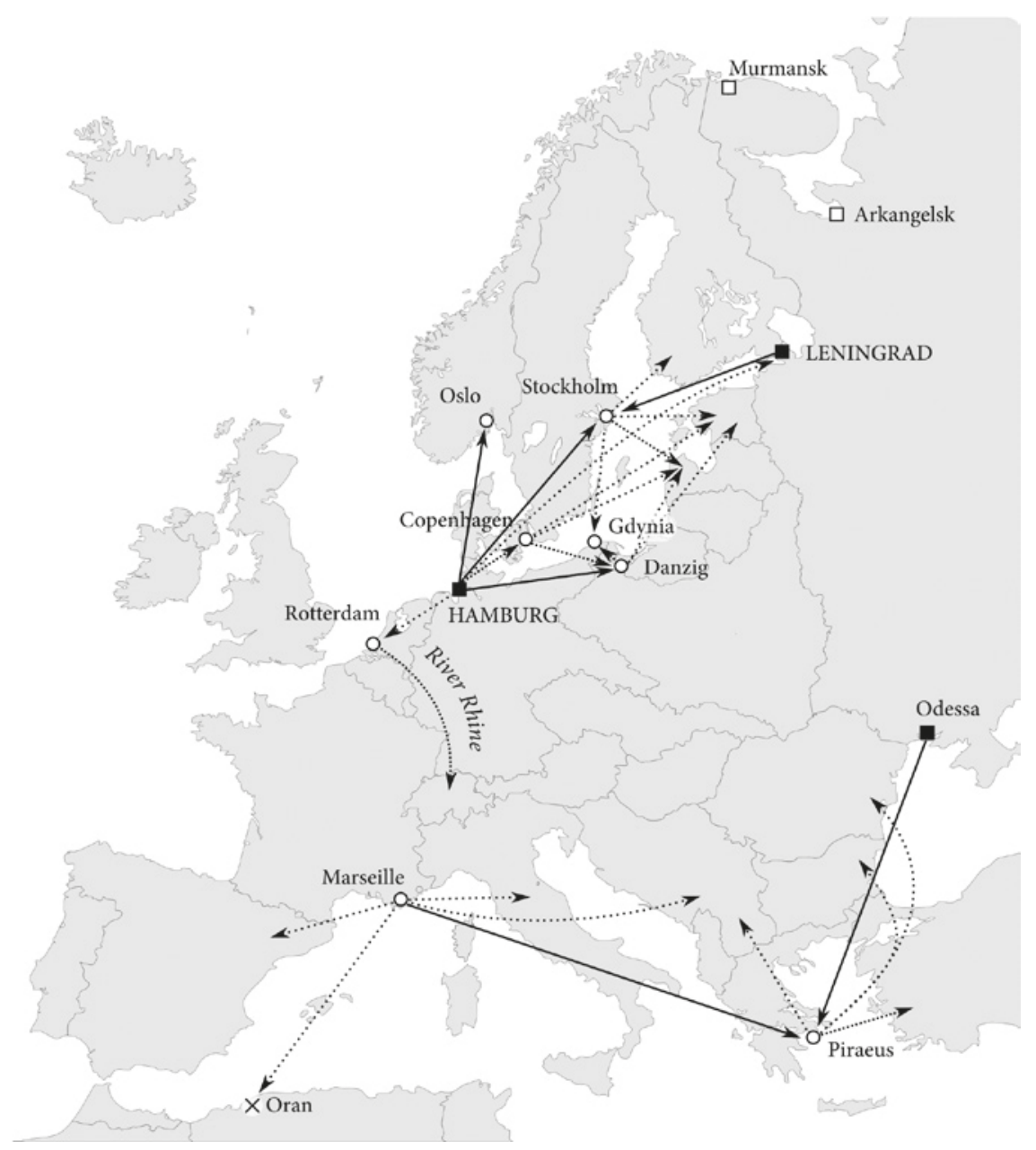

MAP 2 Plan of the internal communication network between European Interclubs

Bulgarian, Italian, Romanian, Turkish and Yugoslavian crews. The Interclubs in New Orleans and New York were to focus on Caribbean, Latin American and Philipino mariners. Finally, work among colonial and 'coloured' seamen was to be conducted by the Interclubs in Antwerp, Hamburg, London, Marseille, Rotterdam and Vladivostok. ${ }^{251}$

251 Decisions of the II. Plenary Session of the Executive Committee of the ISH on the Activity and Tasks of the International Seamen's Clubs, September 1931, 534/5/224, RGASPI. 


\section{4 "Our Office is in a Total Mess"}

The 1931 September meeting also resulted in a revision of work among colonial seamen in Hamburg. ${ }^{252}$ Following by the RILU directives to the ISH and the ITUCNW, the Hamburg Interclub together with the Einheitsverband was to focus on the Indian and Chinese seamen whereas the organisation of black seamen were to be the joint responsibility of the Hamburg Interclub and the ITUCNW. ${ }^{253}$ The implementation of the latter part of the plan had to be postponed as Ford was called to Moscow for a meeting. ${ }^{254}$

Ford never returned to Hamburg. Instead, his replacement was George Padmore, who arrived in Hamburg in early November 1931. The German seamen's strike, launched by the Einheitsverband in early October, had delayed his departure from Moscow. His first impressions of working conditions in Hamburg were rather negative: The harbour area was in chaos and the ITUCNW office in "a total mess" as the police had daily raided the premises at Rothesoodstrasse during the strike. ${ }^{255}$ Padmore managed to meet the Is $\mathrm{H}$ leadership and set up the terms of conditions for his work: He was to receive the services of a stenographer for three days per week. ${ }^{256}$

Padmore's nomination followed a revision of the objectives of the ITUCNW. In October 1931, the ECCI rejected the idea of the RILU to develop the ITUCNW into an outright Black International. Consequently, the RILU adopted a new organisational outline for the ITUCNW, restricting its activities to Africa and the Caribbean. Nevertheless, the obligation to focus black mariners remained, and the RILU stressed the utmost importance of cooperating with the ISH: "It

252 Adolf [Shelley] to "Werte Genossen," Hamburg, 24.11.1931, 534/5/223, 84-98, RGASPI.

253 ISH, Decisions of the II Plenary Session of the Executive Committee of the ISH on the Activity and Tasks of the International Seamen's Clubs, September 1931, 534/5/224, 197198, RGASPI.

254 Paul [Max Ziese] to "Pol" [Luigi Polano?], [Berlin] 17.9.1931, 534/4/355, 77, RGASPI. After his arrival in Moscow, Ford wrote a lengthy report about his activities in Hamburg, including the establishment of a network among black seamen, see (Ford), Report on the Work of International Trade Union Committee of Negro Workers (Hamburg), Covering the Period from December 193 o to September 1931, 8.10.1931, 534/3/669, 221-242, RGASPI.

255 Padmore to "Dear Comrades," add: "für Otto Huiswood," Hamburg, 16.11.1931, 534/3/668, 120r, RGASPI. See further Weiss, Framing a Radical African Atlantic, 302-303. On the German seamen's strike and the role of the Einheitsverband and the ISH, see Constance Margain, "The German section of the International of Sailors and Harbour Workers," Weimar Communism as Mass Movement 1918-1933, eds. Ralf Hoffrogge and Norman LaPorte (London: Lawrence \& Wishart, 2017), 170-186.

256 Padmore to Huiswoud, Hamburg, 16.11.1931, 534/3/668, 121, RGASPI. In addition, it was agreed that the ISH continued to give stamps and to cover the printing costs of The Negro Worker. See Padmore to "Dear Comrade Adolf" [Shelley], Hamburg, 10.12.1931, 534/3/668, 132, RGASPI. 
is necessary to state that the Hamburg Committee [i.e, the ITUCNW] must in no way attempt to isolate the Negro seamen and dockers from the revolutionary organisations of the ISH."257

World depression crippled the shipping industry for its third year in 1931. The ship owners responded to the crisis by terminating tariffs and announcing drastic cuts in wages and preparing rationalisations on board their ships. The leadership of seamen unions tried to handle the situation through negotiations and proposing compromises. Their tactics received heavy criticism from the revolutionary opposition who pushed for confrontation and called the seamen to prepare for strikes. The clashes within the unions resulted in turbulence on the vessels and in the harbours, leading to strikes induced by the revolutionary opposition. The union leadership as well as the shipping industry generally branded these strikes as 'wild' ones, declaring them to breach existing agreements. The ISH and the revolutionary opposition, in contrast, heralded them to be expressions of the suffering masses and signified their resolute fight against the exploitation and 'fascist' methods of the capitalists and their lackeys, the union leaders. Furthermore, the ISH leadership identified confrontation tactics as the best way to promote the revolutionary opposition and to expand its influence among the maritime transport workers' unions.

The ISH and its national sections unleashed a broadside campaign against the ITF and the national unions in fall 1931. The background for the open confrontation was the successful intervention of the ISH and the Einheitsverband Danzig in the Polish seamen's strike in Gdynia by nullifying the attempt of the shipowners to secure blacklegs from Danzig. ${ }^{258}$ The ISH Secretariat had managed to establish a Solidarity Fund for assisting strikers, among its first tokens of financial support were sent to striking fishermen in Havana (Cuba) as well as striking harbour workers in Portugal and Copenhagen. ${ }^{259}$ The Polish strike spurred the ISH to call for a general application of 'militant international solidarity actions': National strikes were to be supported by international boycotts and interventions. A national strike was to be backed by blocking striking

\footnotetext{
257 (Draft) Resolution on work of the Hamburg Committee, 18.10.1931, 534/3/668, 45. See further Weiss, Framing a Radical African Atlantic, 320-322.

258 "Die polnischen Seeleute geben ein Kampfbeispiel," Informations-Bulletin der ISH. Deutsche Ausgabe 1, no. 2 (10. Juli 1931): 6-7.

259 ISH, MR September-October 1931, 534/5/223, 2O, RGASPI.
} 
vessels in any port of the world, by sending agitators to convince the ship crew to join the strike and to refuse to hire on vessels in boycott. The new tactics of militant internationalisation of strikes was first to be implemented during the impending strike of German seamen, and calls for international actions were sent to the ISH sections in late September $1931 .{ }^{260}$

\subsection{Always Fight to the Bitter End}

The Einheitsverband had launched the German seamen's strike in early October $1931{ }^{261}$ German crews went on strike of the first time also abroad, among others in Soviet ports, New York, Liverpool, London, Rotterdam, Antwerp, Copenhagen and Danzig. ${ }^{262}$ The Is H Secretariat heralded actions in support of the strikers as prime examples of international proletarian solidarity. Kouyaté and the Marseille Interclub, for example, organised a blockade of the German steamer Patria and a collection in support for the striking crew. Somali and Djibouti seamen refused to sign on in replacement of the German crew in strike, declaring that they had no intention to serve as scabs. Kouyatés campaign was effective: The captain was compelled to adhere to the old wage rates; the German General Consul in Marseille verified his decision. ${ }^{263}$

The international actions resulted in the German trade union and the shipping industry to define the strike as a 'wild' one and declared it a breach against German maritime law. Tough counter-measures unleashed by the German authorities and unions quelled the confrontation tactics of the communists. The Hamburg police declared the harbour area as well as Rothesoodstrasse to be under curfew, raided the Interclub, and arrested both the leadership of the strike committee and the members of the ISH Secretariat. The unions, in turn, started negotiations, accepted a compromise, and called the strike off. The Einheitsverband vehemently called for a continuation of the strike but without much success and little backing by the rank-and-file members of the union. ${ }^{264}$

\footnotetext{
260 "Aufruf an das internationale Wassertransportproletariat," Informations-Bulletin der ISH. Deutsche Ausgabe 1, no. 6-7 (28. September 1931): 4.

261 "Rüstet zum Strejk!," Rote Wacht. Reichsorgan des Einheitsverbandes der Seeleute, Hafenarbeiter und Binnenschiffer, Sektion der Internationale der Seeleute und Hafenarbeiter (ISH) 2, no. 21 (1931).

262 ISH, MR September-October 1931, 534/5/223, 20, RGASPI.

$263 \mathrm{G}$ [aran] K[ouyaté], Report on colonial seamen, no date [ca. January/February 1932], 534/ 5/230, 25, RGASPI.

264 See further Margain, "The German section of the International of Sailors and Harbour Workers."
} 
The defeat in the German strike did not result into a change of tactics. On the contrary, the leadership of the Einheitsverband and the ISH were convinced that the strike had been lost due to the 'betrayal' of the 'social fascist' union leadership. They further vehemently claimed that uncompromising application of the confrontation tactics and the militarisation and politicisation of strikes was the only way to win a strike; negotiations were a sign of weakness and paved the way for capitulation and defeat. Besides, the implementation of the 'Class-Against-Class'-doctrine would open the eyes of the rank-and-file members of the unions and pave the way for the 'United front from below'.

The blind belief of confrontation being the superior tactics turned into a dogma of the ISH leadership. Disregarding news about defeats in national strikes, they stubbornly adhered to the confrontation tactics. A new attempt by the Einheitsverband to launch a strike in Germany in January $193^{2}$ failed miserably as it found little support among the seamen. The SMM failed in the same month to highjack the strike committees of harbour workers in England. Similar pathetic results were reported in February 1932 when the SMм initiated work stoppages on British vessels protesting wage cuts agreed by the National Union of Seamen. Nevertheless, the Sмм failed in its attempt to call for a nationwide strike and the strike was called off two days later (see further Chapter 7.1.2). The reaction of the ISH leadership on the debacle in England resembled Moscow's instructions: Utilise the (believed) militancy of seamen and launch a red seamen's union! 265

Far better news reached the ISH headquarters from the France and the Netherlands. Here, the revolutionary opposition had gained strength following its successful veto to planned wage cuts. ${ }^{266}$ Even better news came from Iceland where the crews on the fishing fleet went on strike in January 1932 and the strike leadership appealed to the ISH for international support. Hitherto, the ISH Secretariat had failed in its attempts to establish contacts with the unions in Iceland; hence, it immediately disseminated the appeal from Iceland to the IS H sections as a call for international support. ${ }^{267}$ (If the call ever generated any response is not known.)

\subsection{Interventions and Reorganisations}

National strikes were lost if international support was not forthcoming or if the national section of the ISH was unorganised. Weak but strategically important sections had therefore to be reorganised by the ISH Secretariat, either by

265 ISH, Situationsbericht 1.1.-15.2.1932, 534/5/230, 42-43, RGASPI.

266 ISH, Situationsbericht 1.1.-15.2.1932, 534/5/230, 43-44, RGASPI.

267 ISH, Situationsbericht 1.1.-15.2.1932, 534/5/230, 44, RGASPI. 
issuing written orders or directly intervening by deploying an instructor to the section. The first strategy was applied by the IsH Secretariat in its attempt to reorganise work in North America as it had neither funds nor suitable personnel at its disposal for a direct intervention. The reorganisation of the Marine Workers' Industrial Union (MWIU) in the USA resulted in the nomination of a new collective leadership (in early 1932, although the effect of the IsH intervention it is questionable). ${ }^{268}$

Sending instructors with unlimited power to intervene in national sections was at first only applicable in Europe. Adolf Shelley therefore went to Berlin to discuss a revision of strategic and tactical operations with Pechmann and Ziese at the RILU Berlin Bureau in late October $1931 .{ }^{269}$ As an outcome of the meeting, Shelley designed in November 1931 an ambitious plan to expand the number of instructors. Johannes Koschnik was to be nominated as instructor responsible for reorganisation of work in the Netherlands, Northern Europe and Poland. Comrade Kodrnja, whom Shelley regarded as amply qualified as he spoke Bulgarian, Croatian, Czech, German and Serbian, was to reinvigorate work in the Danube countries and Greece. Liao Chenghzi was to be sent to the Far East, the Sierra Leonean seaman Foster Jones, who had been engaged as contact person already by James W. Ford, to be sent to West Africa, and a certain comrade Contreras to be deployed from Moscow to Latin America. 270

However, for reasons not known, Shelley's plan was never implemented. Instead, the ISH Secretariat engaged two instructors in France, "Marcel" and "Henry". The former, whose identity is not known, was charged by the ISH Secretariat to start a total reorganisation of the FUMP. ${ }^{271}$ The operational area of "Henry", i.e., Luigi Polano, were the Mediterranean countries as well as connections to Latin America. His intervention achieved mixed results. Clandestine work in Italy had resulted in the establishment of local illegal units of the FILM in five ports in addition to sea cells on 80 Italian vessels. By the end of 1931, the FILM counted some 600 members in addition to 100 in Marseille. ${ }^{272}$ Polano's activities in Spain, too, were successful - the local branches of the harbour worker's and seamen's unions in Barcelona and Seville considered affiliating to the ISH. Less promising was the situation in Portugal, Greece and Latin America. Communist activities were illegal in the two former countries while the Uruguayan

\footnotetext{
268 Pedersen, The Communist Party on the American Waterfront, 37, 47-48.

269 Paul [Max Ziese] to "Pol" [Luigi Polano?], [Berlin] 21.10.1931 and 26.10.1931, 534/4/355, 131, 141, RGASPI.

270 Adolf [Shelley] to "Werte Genossen," Hamburg 24.11.1931, 534/5/223, 88, RGASPI.

271 ISH, Situationsbericht 1.1.-15.2.1932, 534/5/230, 44-46. RGASPI.

272 Leo [Pechmann] to "Werte Genossen," [Berlin] 21.11.1931, 534/4/353, 82, RGASPI.
} 
government was preparing a proposition to curb communist activities by banning their organisations. As a preventative measure, the RILU Latin American Secretariat in Montevideo moved underground which, in turn, severely blocked its communications with Polano and the ISH Secretariat in Hamburg. ${ }^{273}$

The ISH Secretariat also considered intervening in the German section. The miserable outcome of the German strike in October 1931 as well as stagnating membership of the Einheitsverband raised concern at the ISH headquarters. ${ }^{274}$ A replacement of the leadership of the Einheitsverband was effectuated in February (?) 1932 when Ernst Wollweber substituted Johannes Koschnik. Wollweber's nomination as head of the Einheitsverband might have been decided in Hamburg or in Berlin as the plan was discussed in a blueprint for strengthening the organisational work of the ISH in late February/early March $1932 .{ }^{275}$ Wollweber was a well-known character to both the party and the authorities. He had served on a submarine during the war and instigated a rebellion among its crew in Kiel in November 1918. He joined the KPD in 1919 and quickly rose in the ranks of the party. By 1921, he had become a member of the party's Central Committee and Political Secretary of the Hesse-Waldeck district. Wollweber was notorious for his work behind the curtains and became a master of clandestine operations. Arrested and charged with high treason in 1924, released in 1926, he was a member of the Prussian Federal State Parliament since 1928. ${ }^{276}$ British Intelligence sources claim that Wollweber participated as representative of the Reich Committee of the RGO at the ISH Executive Committee meeting in September 1931. ${ }^{277}$

\subsection{The March 1932 Proposal for Global Work}

Wollweber's relocation to Hamburg was part of an ambitious design by the ISH leadership in early March 1932 to overhaul both the ISH Secretariat and the national sections. According to the March $193^{2}$ Proposal, two additional

273 ISH, Situationsbericht 1.1.-15.2.1932, 534/5/230, 44-46, RGASPI.

274 ISH, Situationsbericht 1.1.-15.2.1932, 534/5/230, 44-46, RGASPI. The membership of the Einheitverein had stagnated to circa 10,00o members in early 1932, see Margain, L'Internationale des gens de la mer, 339, Figure 1.

275 Adolf [Shelley], [Albert] Walter, [?] Stein, Vorschläge zur Stärkung der organisatorischen Arbeit der ISH, [Hamburg] 1.3.1932, 534/5/230, 53, RGASPI. The identity of "Stein" is not known although I assume that it was one of Wollweber's pseudonyms. Margain makes a dubious claim (L'Internationale des gens de la mer, $360-361$ ) that Wollweber took over as leader of the Einheitsverband already in 1931.

276 Ernst Behrend, Formular (1934), Erich Wollweber personal file, 495/205/8628, 4-5, RGASPI. Behrend was one of Wollweber's pseudonyms.

277 Cross-Reference 30.9.1931, Erich Wollweber personal file, KV2/3054, 1a, TNA. 
instructors were to be engaged. The first one was to operate in San Francisco, charged to establish a local bureau of the ISH and to start work among Japanese seamen. The second one was to serve as a travelling instructor and monitor the work of the Interclubs. Only two members of the ISH Secretariat were to remain in Hamburg, the rest were to be posted in various countries and strengthen the work of the respective national sections of the IS H. ${ }^{278}$

The blueprint stressed the need to open new avenues for agitation in countries where communist activities were illegal. The key idea was to charge certain Interclubs to concentrate on specific target groups - Danzig on Polish, Stockholm on Baltic and Finnish, Vienna on Romanian and Greek, and Marseille on Italian and Yugoslavian mariners. Underground or illegal Interclubs were to be established in Lisbon and Piraeus. ${ }^{279}$

Colonial seamen were a specific target group in British, Belgian and Dutch ports. The sмm was projected to establish a new Interclub in Cardiff that was to focus on agitation among black seamen as well as to connect with seamen in West Africa. The Interclub in Antwerp, in turn, was charged to open links to Belgian Congo, while the Interclub in Rotterdam was to focus on Indonesian seamen. Outside Europe, the ambition was to establish an Interclub in Freetown in Sierra Leone in cooperation with the ITUCNW. The organisation of Caribbean seamen and harbour workers was to be the prime target of a new Interclub projected in Havana as well as the existing one in New Orleans. ${ }^{280}$ The March 1932 Proposal correlated in this respect with the intention of the RILU Latin American Secretariat to establish a new bureau in New York for coordinating its work in the Caribbean region. ${ }^{281}$ Further, the IS H leadership projected the (illegal) Interclub in Montevideo together with two new ones in Buenos Aires and Santos to focus on work among Latin American seamen. In the Pacific area, the revolutionary trade union opposition in Australia and New Zealand were envisioned to link up with RILU Pan-Pacific Secretariat and eventually to affiliate with the ISH. ${ }^{282}$

278 Adolf, Walter, Stein, Vorschläge zur Stärkung der organisatorischen Arbeit der ISH, [Hamburg] 1.3.1932, 534/5/230, 52, RGASPI.

279 Adolf, Walter, Stein, Vorschläge zur Stärkung der organisatorischen Arbeit der ISH, [Hamburg] 1.3.1932, 534/5/230, 53-55, RGASPI.

28 o Adolf, Walter, Stein, Vorschläge zur Stärkung der organisatorischen Arbeit der ISH, [Hamburg] 1.3.1932, 534/5/230, 53, 55, RGASPI.

281 Confederacion Sindical Latino-Americana, Sub-Comité del Caribe, New York, Resolution of the Work of the Sub-Committee Amongst the Marine and Port Workers in the Caribbean, no date [ca. February/March 1932], 534/4/427, 9-10, RGASPI.

282 Adolf, Walter, Stein, Vorschläge zur Stärkung der organisatorischen Arbeit der ISH, [Hamburg] 1.3.1932, 534/5/230, 55, RGASPI. 
The implementation of the March 1932 Proposal proved difficult. Some of its global visions, such as the push towards West Africa, proved impracticable (see Section 4.5 in this chapter). Others were materialised, such as the organisation of the bureaus in San Francisco and New York. In Europe, the situation in England continued to be pathetic (see Chapter 7.2.2). On the other hand, the IS H headquarters could list two operational successes by May 1932, namely the arrangement of a conference for river transport workers on the Danube as well as the establishment of illegal sections in Estonia, Finland and Latvia.

The Danube Conference has not left many traces. Summoned to an unknown location in April 1932, its outcome was the formation of a special ISH Danube Committee. ${ }^{283}$ The operational area and organisational links of the ISH Danube Committee is reflected by the composition of its members, namely representing the ISH Secretariat and the RILU Berlin Bureau as well as the red unions/revolutionary oppositions in Austria, Bulgaria, Czechoslovakia, Germany, Hungary, Romania and Yugoslavia. The secretariat of the Danube Committee was placed in Vienna and charged to publish a journal, Donauwacht, in six languages. ${ }^{284}$

As expected, the conference ended with the adoption of a resolution denouncing the ITF and the 'social fascist' national trade union leaders as well as presenting the ISH to be the only defender of the maritime transport workers. ${ }^{285}$ However, the establishing of - mostly illegal - sections in the Danube region proved soon illusionary. The Yugoslavian Party was not interested in detaching a functionary to the Interclub in Vienna, the Czech red trade union never replied to the invitations of the IsH, and the German Party and the RGO seemed indifferent to agitate among the Danube river transport workers. Not less challenging was the situation in the other countries with either nonexisting union organisation in Bulgaria, Hungary and Romania or a crushed union in Yugoslavia. 286

Equally challenging was work in the Baltic region. However, the ISH headquarters implemented a successful strategy to circumvent legal barriers by establishing phantom 'sections' of the revolutionary opposition in the seamen's

283 Walter to "Werte Genossen," [Hamburg], 2.12.1932, 534/5/231, 83, RGASPI.

284 Vertrauliche Beschlüsse zur Resolution der I. Donaukonferenz der Schiffer und Hafenarbeiter, no date [ca. April 1932], 534/5/321, 85-9o, RGASPI.

285 Resolution der I. internationalen Donaukonferenz zur Lage der Wassertransportarbeiter der Donau und den Aufgaben der revolutionären Gewerkschaftsbewegung im Kampf gegen die Ausbeuter und den imperialistischen Krieg, no date [1932], 534/5/231, 91-95, RGASPI.

286 Vertrauliche Beschlüsse zur Resolution der I. Donaukonferenz der Schiffer und Hafenarbeiter, no date [ca. April 1932], 534/5/231, 85-9o, RGASPI. 
unions in Estonia, Finland and Latvia. None of these 'sections' ever existed formally. However, in late spring 1932 three new publications were distributed among Baltic and Finnish seamen - the Estonian Majakas, the Finnish Majakka and the Latvian Baka. ${ }^{287}$ Each of them claimed to be published by a national 'sections' of the ISH with editorial headquarters at the Interclub in Hamburg, sometimes even referring to Albert Walter as editor in chief, see Figure 16.288

"Hands off China!" - Orchestrating a Global Campaign against Japanese Imperialism

Global political campaigns launched by various communist organisations after 1928 adhered to the 'Class-against-Class'-doctrine and had to receive official backing from the Comintern headquarters. However, in contrast to the earlier 'United front'-tactic of inviting non-communist radical organisations and activists to join a campaign, the new doctrine of 'United front from below' rejected any official cooperation with non-communist radical organisations though still inviting non-communists to join the campaign. In addition, any campaign launched after 1928 was to correlate with Soviet foreign security doctrines, as was underlined in the 1927 Imperial War Theses. According to these theses, any so-called imperialist war or conflict could develop into a new World War that ultimately aimed to eradicate the Soviet Union. ${ }^{289}$ Communist parties and labour unions where therefore to establish anti-war committees and to organise boycotts of the shipment of military equipment to theatres of war anywhere on the globe. ${ }^{290}$

The test case for the ISH came during the 1931-32 Manchurian Crisis. While Soviet foreign policy officially applied strict neutrality, ${ }^{291}$ the Comintern and the RILU started an international solidarity campaign against

287 Interestingly, baka, majakas, and majakka means 'lighthouse' in English.

288 Weiss, För kampen internationellt!, 307-308.

289 See "Extracts from the Resolution of the Tenth EcCI Plenum on the International Day of Struggle Against Imperialist War, July 1929," in Communist International 1919-1943. Documents, Volume II. 1919-1943, ed. Jane Degras (London and New York: Frank Cass, 1971), $377-381$.

290 ISH: An alle Seeleute, Hafenarbeiter und Binnenschiffer! Grosse Gefahr des drohenden Angriffs der Imperialisten auf den Sowjetstaat: Schützt die Sowjetunion, in: Rotes Gewerkschafts-Bulletin 78, no. 9 (13.12.1930), R1501/20224 Reichsministerium des Inneren. Internationale Hafenbüros und Seemannklubs, Jan. 1930-Nov. 1933, 31, BArchB.

291 Jonathan Haslam, Soviet Foreign Policy 1930-1933: The Impact of the Depression (London and Basingstoke: Palgrave, 1983), 79-82. 


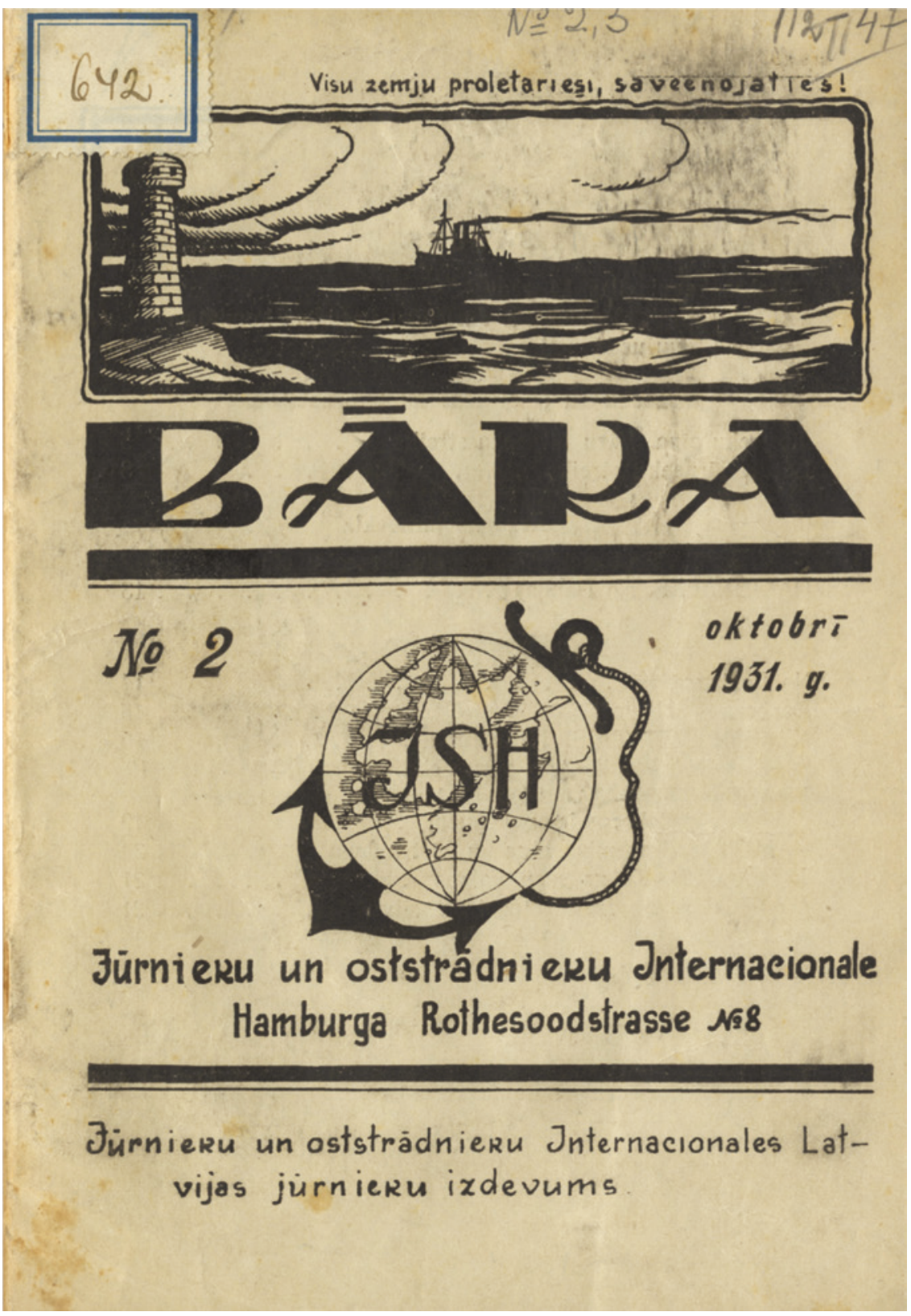

FIGURE $16 \quad B a k a$, the publication of the Latvian section of the ISH. 
Japanese imperialism and militarism when the West European Bureau of the Comintern and the RILU European Bureau issued a joint statement condemning the Japanese attack on China in September $1931 .{ }^{292}$ Georgi Dimitrov, the head of the West European Bureau, sent a message to Moscow and urged the Comintern to issue an order to all communist parties to step up a campaign against the war danger and in defence of the Soviet Union. However, the Comintern headquarters were slow to react. Only in November did the Comintern issue an appeal where it warned that the Far Eastern conflict might lead to a world war and that the Japanese were preparing to attack the Soviet Union. The appeal included a call to establish China aid committees and to organise protest meetings and demonstrations against the Japanese aggression. ${ }^{293}$

The 'Hands off China!'-campaign was rather successfully carried out by communist non-party mass-organisations, such as the Workers' International Relief (Internationale Arbeiterhilfe) which had almost ten years of experience in mobilising for proletarian international solidarity. ${ }^{294}$ Mass mobilisation for China through the communist parties, on the other hand, proved difficult. In Britain, for example, George Hardy blamed the lack of political mobilisation during its opening phase in the autumn of 1931 on the fact that few workers had any idea of the conflict, lest knew where Manchuria was located. ${ }^{295}$ The inactivity of the communist parties resulted in harsh criticism from the Comintern. After the attack by Japanese forces on Shanghai in late January 1932, the stronghold of the Chinese Communist Party, the Comintern demanded outright action from the communist parties. ${ }^{296}$ Consequently, the British Communist Party made substantial effort during the spring of $193^{2}$ at popular mobilisation on the left. However, the campaign did not match expectations and the failure to involve the industrial workers resulted in much self-criticism. ${ }^{297}$

292 "Appeal by the West European Bureau of the ECCI and the European Secretariat of the RILU on the Japanese Invasion of Manchuria," Inprecorr XI, no. 93 (29 September 1931): 2080.

293 Haslam, Soviet Foreign Policy, 86-87; Belugova, "Networks, Parties, and the 'Oppressed Nations."

294 See further Kasper Braskén, "In Pursuit of Global International Solidarity? The Transnational Networks of the International Workers' Relief, 1921-1935," in International Communism and Transnational Solidarity: Radical Networks, Mass Movements and Global Politics, 1919-1939, ed. Holger Weiss (Leiden and Boston: Brill, 2017), 130-167.

295 Buchanan, East Wind, 53.

296 Haslam, Soviet Foreign Policy, 87-88.

297 Buchanan, East Wind, 54-55. 
The 'Hands off China!'-campaign was the first global call for international political mobilisation the ISH, see Figure 17.298 The objective of the campaign, the ISH Secretariat informed its national sections in December 1931, was twofold. First, the task was to expose the ITF for its 'social fascist' tendencies and its support for imperialist war efforts. Second, the national sections were to establish local anti-war committees. The ITF was accused for bluffing - its call to stop the transportation of war material to the Far East was claimed to be bogus; instead, the ISH called to the seamen to boycott all shipments of military material to Japan. ${ }^{299}$ Already in its Resolution on colonial work of March 1931, the IS H accused 'social fascist' trade union leaders of the ITF for splitting the ranks of the sea transport workers, among others in Japan and China. ${ }^{300}$ In its first reaction to the Manchurian Crisis, the ISH denounced the ITF for not having condemned Japanese imperialism neither the attack against Manchuria. ${ }^{301} \mathrm{On}$ the contrary, the ISH informed its members, the 'reformist' Japanese seamen union backed its government and the leadership of the British seamen union had rejected the call to boycott Japanese ships. In addition, in line with the Imperialist War theses, the Japanese attack was believed to be the first stage of a forthcoming imperialist attack upon the Soviet Union. ${ }^{302}$

The progress - and difficulties - of the 'Hands off China!'-campaign will be outlined below by focusing on the activities of the national sections of the ISH in the Scandinavian countries. A pamphlet of the ISH was translated into Danish and highlighted the crucial role of the Danish harbour workers as they had the task to block any shipment of war material through the Danish Sounds and on Danish ships. ${ }^{303}$ In Sweden, the war danger and the Manchurian Crisis were the prime topic of the national congress of the radical sea transport workers in December $1931 .{ }^{304}$ If the initial calls of the ISH and its national sections had any immediate effects is unclear. It is more likely that the national

298 The following sub-chapter paraphrases the first part of my article, Holger Weiss, "Against Japanese and Italian Imperialism: The Anti-war Campaigns of Communist International Trade Union Organizations, 1931-1936," Moving the Social:Journal of Social History and the History of Social Movements 6o (2018): 121-146.

299 "ITF och kampen mot kriget," Ny Dag 4.12.1931.

300 Resolution on the Colonial Work of the Sections of the ISH in the Capitalist Countries, 22.3.1931, 495/25/1334, RGASPI.

301 "ITF och kampen mot kriget," Ny Dag 4.12.1931; Borgersrud, Wollweber-organisasjonen i Norge, 55 .

302 ITF-kongressen i Belysning af Officielle Dokumenter [ca. 1932], p. 2, Richard Jensen's papers, ABA.

303 (ISH pamphet) Søfolk! Havnearbejdere! [published ca. 1932], Richard Jensen’s papers, ABA.

304 "R.F.O.:s landskonferens," Hamn- och sjöproletären 1, no. 2 (December 1931): 5. 


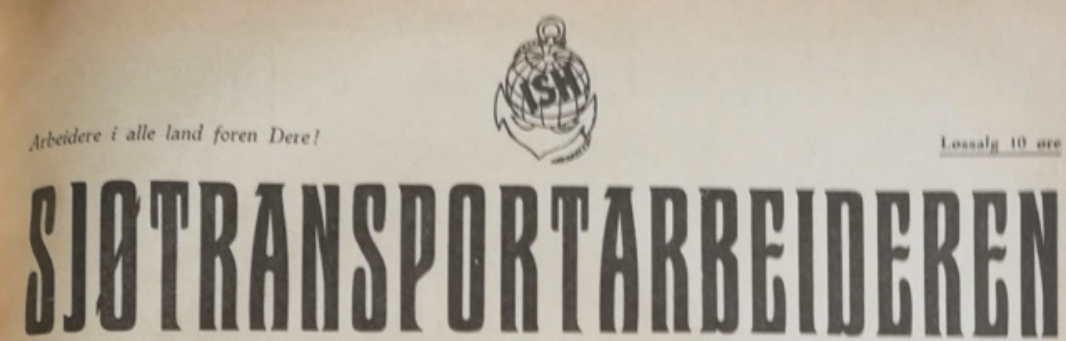

Utgitt av Sjetransportarbeidernes revoluajonere Opposinjon i Norge.

Nr. 2.

\title{
Krigen $i$ Osten $i$ full gang. Til alle sjofolk og bryggearbeidere.
}

\begin{abstract}
KAMERATER !
For flere manteder tilbake har I. S. H. I et oprop pápekt at okkupasjonen av Mansjuriet intet annet betyr enn en ny Imperialistisk krig. Eifter at de japanske Imperialister med stette av de evrige imperiallstiske stater har besatt Mansjuriet, har de nu pá- 1 . begynt et fryktelig bombardement av Shanghal, Nanking og Charbin. I bombardementet be-

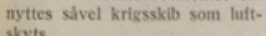

Charbin er det centrale punkt pâ den Ostkinesiske bane som stâr under ledelse av sovjets og kinesiske funksjonkerer.

Hvad betyr bombarde mentet av disse byer?

Besettelsen av Shanghal ved strateg- reren for Englands arbeiderparti. disse skulde ga tapt, fär rederne en enhetsiront as alle sjofolk.

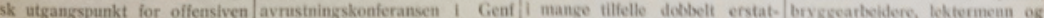

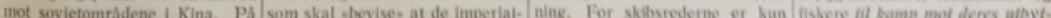
samme máte betyr imperialiste- Istiske makter Ikke vil krig, men def viktigste a heste sterre pre- tere og malerirykAvre. Deite ef nes besettelse av Charbin et cen- avrustning. Gjennem fascisme, fitt og komme sig ut av krisen. samtidis den beste kamp dere ter for angrepene pâ Sovjet- bedrageriske fraser, gjennem lin- selv om miltioner av mennesker kan fore mot do lumperiatistiske Unionen. perialistiske komedier med sav- derigjennem má sefte livet tit.

Den imperialistiske krig fden eneste fredens borg og det er f verdenskrig, for a holde arbel kan Run forhindres gien. Sovjet-Unionen hvor man byg- derklassen nede. siennem blodis nem rovolusfonar Ramp ger op sociallsmen og sou I dis- terror og standretter skal man av werdensprotetariatet. se dager giennemiorer sin forste forseke a bole massenes util. \begin{tabular}{ll|l} 
2. internasiomale og 1.5 árs plan. & fredshet, sla ned den revolusjo- \\
T. Fs rolle.
\end{tabular} T. F.s rothe.

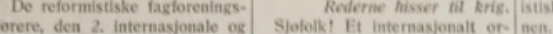

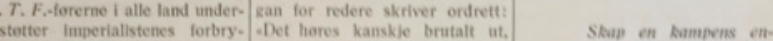
stske aksjoner.
inen it fra den sltuasjon som hetsirent.

Edo Fimmen, I. T. F.s geteral- man nu star overfor er en kns Sjetransportarbeldere I allo

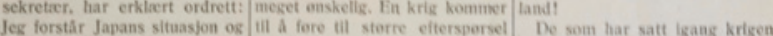
at det ikke kan la sine borgere I efter tonnasje, varetransportens I Osten er de samme soin nedKina stă ubeskyttets, Gjennem risiko vil stice, og dermed egsa setter deres lanninzer og forverJenne erklering har Fimmen prisene og nod dette vill samtl- rer deres arteldskár. De samme anerkjent de japanske imperial- dig spekulasjonen stiges.

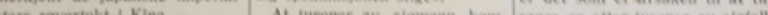
ters rovertokt I Kina. At tusener av sjomen hom- sener og atter tisener av sjofolk

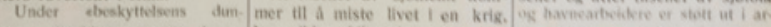
dring, maskingeverenes knat- bryr ikke skibsrederne sig oan. beldsloshet og elendighet. Orgaroner. nustnings lar imidlertid verdens

-Folkeforbundet, enig sjotransportarbeldere sig lkke En ny wedenskrig iraver

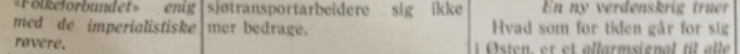

Folkeforbundet bar allerede fra begynnelsen av stilt sig pa samme linje som de fapanske rovere, fordi de forbereder en nyopdeling av Kina, fordi de for-

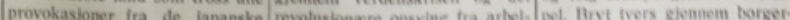

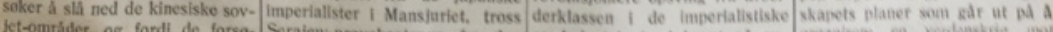

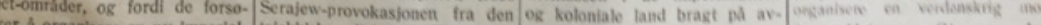

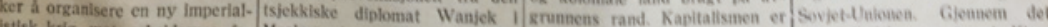
istlsk krig mot arbeidemes fe- Moskva, tross alle de ovrige beredt til alle skurtestreker for limerlalistiske eventyr I Kina.

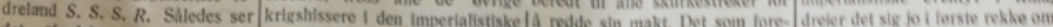

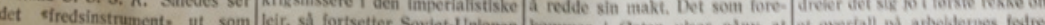

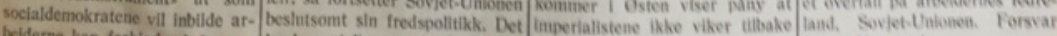

FIGURE 17 Protesting against the Japanese invasion of Manchuria, reports on actions against Japanese imperialism following the Is $\mathrm{H}$ 'Hands-off-China'-campaign, published in Sjøtransportarbeideren 2, no 6 (February 1932): 1. The journal was the organ of the Is H section in Norway. 
sections started its propaganda and agitation campaign after the new call by the RILU Berlin Bureau in February 1932, directed to all metal and harbour workers to prevent the transportation of military supplies destined for the use against China and the Soviet Union. ${ }^{305}$ As the ISH fully backed the call, the national sections had to act. Anti-war meetings were organised, among others, in Stockholm in Sweden and the Swedish section issued a resolution that criticised the Reformist leaders for inactivity and sabotaging local boycotts. ${ }^{306}$ In Denmark, both the seamen's and the stokers' unions issued resolutions condemning an (impending) attack on the Soviet Union and Soviet China. ${ }^{307}$ The first anti-war committee was established in Gothenburg in March and one month later the Hamn- och sjöproletären, the organ of the Swedish ISH section, reminded its readers of the utmost need to establish anti-war committees in each harbour as military equipment also had been shipped to the Far East. ${ }^{308}$ Similar calls were published by the RFO-journals in Denmark and Norway. ${ }^{309}$

If the call to form anti-war committees in the Scandinavian countries had a profound effect is not known. Still, there are some indications of their existence. A "mass demonstration" was organised by the harbour workers in Oslo in March, protesting against the Japanese bombardment of Shanghai; ${ }^{310}$ while Danish harbour workers protested in Copenhagen against the shipment of war equipment on Danish vessels to Japan. ${ }^{311}$ One month later, the RFO in the Oslo harbour tried to block the shipment of war equipment to Romanian and Turkish ports; ${ }^{312}$ in May, they protested against the shipment of ammunition on a Norwegian freighter to Japan. ${ }^{313}$ The Manchurian Crisis and the

305 Rote Einheitsfront gegen den räuberischen Überfall auf China und gegen das imperialistische Kriegskomplott gegen die Sowjetunion und Sowjet-China. Kampf gegen die eigenen Ausbeuter und ihre Helfer. Reichskomitee Agitprop Anfang Februar 1932, R1501/ 20442 Reichsministerium des Inneren, KPD - Revolutionäre Gewerkschaftsbewegung, Jan. 1932-Mai 1932, 469, BArchB.

306 "Mot det imperialistiska kriget," Hamn- och sjöproletären 2, no. 2-3 (1932): 2.

307 "Resolution," Lanternen 7, no. 2 (1932): 1; "Resolution," Rød Kurs 2, no. 3 (1932). Both texts had been put forward by the opposition.

308 "Kamp mot kriget - Bilda antikrigskommittéer!," Hamn- och sjöproletären 2, no. 4 (1932): 4.

309 "Krigen raser i Østen!," Rød Kurs 2, no. 2 (1932); "Enhetsfront mod krigen," Lanternen 7 , no. 2 (1932): 2; "Organiser antikrigskomiteer i alle hamner og skib!," Sjøtransportarbeideren 6, no. 3 (1932): 1 .

310 "Massdemonstration i Oslo," Sjøtransportarbeideren 6, no. 3 (1932): 3.

311 “"Peter Mærsk" med ammunition til Japan og besætningen udenom Anvisningerne!," Sjøtransportarbeideren 6, no. 3 (1932).

312 Arbeideren 13.4.1932.

313 "150 ton patroner med "Røsten" fra Oslo til Shanghai," Sjøtransportarbeideren 6, no. 5 $(1932): 4$. 
anticipated/feared Imperial War had been one of the central themes discussed at the World Congress of the ISH in Altona in late May 1932, ${ }^{314}$ not surprisingly resulting in a condemnation of the ITF and its demand to wait for the final decision of the League of Nations. ${ }^{315}$ Danish and Swedish delegates being present at the tactical discussions at the Conference, including the urge to strengthen the work of the national anti-war committees, ${ }^{316}$ it is not surprising that a joint Danish-Swedish anti-war meeting was called to be held in Elsinore in early July. ${ }^{317}$ At least in Gothenburg, the new tactic resulted in the establishment of a 'Vigilance and action committee', the Röd Hamnkontroll (Red Harbour Control). ${ }^{318}$

Locally organised boycotts and anti-war activities were to be utilised in international propaganda and agitation campaigns. A successful boycott anywhere on the globe was to be reported in the national organs of the sections as they were to serve as an example and stimulate for similar actions in the harbours. For example, the readers of Majakka, the organ of the illegal Finnish section of the ISH, were informed about a successful action against the ship Caronia "in an English harbour:" The harbour workers had delayed the departure of the ship by pouring sulphuric acid in its engine. ${ }^{319}$ The Danish RFO-journal Rød Kurs reported about two events, one successful, one failed: in Gothenburg, the dockers' union had rejected the demand of boycotting the freighter Hemland, whereas 23 stokers had tried to stop the Japanese-owned steamer New Amsterdam in Durban (and, as a consequence, were jailed by the South African police). ${ }^{320}$

As anticipated by the IS $\mathrm{H}$, the 'Hands off China!'-campaign was not backed by the leadership of the national unions of sea transport workers in Scandinavia.

314 "Struggle against Imperialist War," in The World Unity Congress of the International Water Transport Workers and it's Decisions (Hamburg: International of Seamen and Harbour Workers, no date [1932]), 13-16.

315 “ITF og krigen i Östen," Rød Kurs - Kongressnummer, Maj 1932 (special edition, May 1932); "Edo Fimmen sanksjonerer ockupasjonen i Mansjuria og transporten av krigsmateriell," Sjøtransportarbeideren 6, no. 5 (1932): 2.

316 "Kämpft gegen den imperialistischen Krieg! Der Erste Einheitskongress des internationalen Wassertransportproletariats an die Seeleute, Hafenarbeteiter, Binnenschiffer und Fischer aller Länder!," Hamburger Volkszeitung, 26.5.1932; "Organisiert das Stoppen der Kriegstransporte! Der internationale Seeleutekongress an das Wasserproletariat der ganzen Welt!," Ruhr-Echo Nr. 110, 28.5.1932, 458/9/54, 78, RGASPI.

317 "Till Helsingör," Hamn- och sjöproletären 2, no. 6 (1932): 4.

318 Stormklockan 9-16.6.1932, sÄPo Äldre Aktsystemet Volym 294 Pärm VIII C 3 Interklubb och Röd Marin, Pärm 1, SNA.

319 "Miten aselaivan lähtö estetään," Majakka 6 ([December] 1932): 32.

320 Rød Kurs - Kongressnummer, Maj 1932 (special edition, May 1932). 
On their part, the union leadership regarded the campaign to be nothing else than a communist move to split the unions. Why boycott the shipment of war equipment to Japan when the Soviet Union was at the same time allowing the transport of Japanese troops on the Soviet-controlled East Manchurian railway, the editor of the Swedish union journal Sjömannen asked? ${ }^{321}$ Also, the so-called peace propaganda of the communists was nothing else than a bluff and one of the few successful boycotts in a Swedish harbour turned out to be directed against a ship carrying gun powder to Turkey, mocked the journal. ${ }^{322}$ The communist journal Hamn- och sjöproletären did not reply to these accusations. Typically, they regarded the reformist critique as nothing else but a veiled attack by the capitalists and ship owners who sided with the Japanese imperialists. Nevertheless, the discrepancies between Soviet and Comintern/ RILU policies during the Manchurian Crisis must have been difficult to explain for the party's rank and file when they were confronted by socialist or nonorganised seamen and harbour workers.

The problem with the various calls for the boycott of military shipments was that they did not result in a mass mobilisation of the local workers. Although the communists tried to organise local strikes and actions in various harbours throughout Western Europe and the USA, they usually failed to prevent the transportation of war equipment to the Japanese forces. In Britain, for example, the radical left as well as the SM M were unable to persuade harbour workers to take action, and vessels loaded with ammunition, such as the Glenshiel in April 1932 and the 'death ship' Glengarry in May 1932, managed to embark from British ports. ${ }^{323}$ Norway, a correspondent of the Sjøtransportarbeideren criticised the unwillingness of the harbor workers' union leadership to organise a boycott in the harbour of Oslo; 324 the only successful blockade was organised in December 1932. ${ }^{325}$ In Sweden, where the formation of harbour cells and anti-war committees had been slow, the national section of the ISH critically remarked that several shipments of war material had left Sweden during the spring of $1932 .{ }^{326}$

321 "Internationell orientering," Sjömannen 5 (1932): 131. An identical text was published one month later in the organ of the Swedish stokers' union Eldaren.

322 “Vad är krigsmaterial och hur förhindra krig?," Sjömannen 8 (1932): 225-226.

323 (Half-burnt copy) Inf. notes 7.4.1932 and 9.4.1932, George Hardy personal file, KV 2/1027, TNA. Buchanan, East Wind, 52 . According to British Intelligence sources, Hardy used eight trusted (unemployed) men to search the docks for ships going to Shanghai.

324 "Oslo bryggearbeidere må ta initiativet til en effektiv blockade av all våben og ammunisjonstransport," Sjøtransportarbeideren 6, no. 6-7 (1932): 2-3.

325 "Norske skibe smuggler ammunisjon inn i Kina," Sjøtransportarbeideren 6, no. 12 (1932): 1.

326 “Kamp mot kriget - Bilda antikrigskommittéer!," Hamn- och sjöproletären 2, no. 4 (1932): 4. 
The Is H Secretariat also made use of the ITUCNW to instigate the 'Hands off China!'-campaign among black mariners. A first call on global solidarity was published in The Negro Worker in late 1931. In line with the Comintern theses on the forthcoming Imperialist War, the black toilers were called to act against the Japanese aggressors and to defend the Soviet Union. ${ }^{327}$ For the next 6 months, The Negro Worker was to carry in each issue calls to join the "Hands off China!"campaign in each issue. In March 1932, the ITUCNW officially rallied behind the Is H's resolution on the war in the Far East and urged black harbour workers and mariners to stop the transportation of war material to Japan. ${ }^{328}$ The covers of both the March and the April issues of The Negro Worker carried the slogans of the global campaign - "Hands off China" and "Defend the Soviet Union!" as well as demanding "Down With the Imperialist War Mongers!" and "Not a Gun for the Imperialist War Mongers!". In May, its readers were reminded that to defend the Soviet Union is to defend the interests of the working-class and were urged to protest against Japanese imperialism and Western interference in China: "Negro Workers! Rally to fight against the Japanese robber war! Against the war inciters and war criminals! For immediate withdrawal of all imperialist troops and gun boats from China! Against the partition of China and for the defense of the Chinese Soviet districts!" 329 Padmore was quick to notify his readers that both France and Britain were supporting Japanese war efforts by sending war materials to the Far East. ${ }^{330}$

However, a close reading of The Negro Worker reveals that the 'Hands off China'-campaign soon became of peripheral interest of the ITUCNW. What mattered more for Padmore was the international campaign in support of the Scottsboro Boys. The 'Scottsboro Boys' were nine young African Americans who had been charged with the rape of two white girls in Scottsboro, Alabama in March 1931. The evidence was dubious and was challenged both by the bourgeois as well as the left-wing press. When the local court sentenced them to death in April 1931, a nationwide wave of protest against the lynch justice in the US South was organised by the International Labor Defence and was made a global affair by the International Red Aid. ${ }^{331}$ In June 1931, the RILU Secretariat ordered the ITUCNW to develop the Scottsboro campaign into a

327 "The War Danger. War in the East. Negro Workers, defend the Soviet Union and the Chinese Revolution!," The Negro Worker, 1, no. 10-11 (October-November 1931): 3 .

328 G.P., "War in the East," The Negro Worker 2, no. 3 (March 1932): 9.

329 Cyril Briggs, "Negro Workers, Fight Against Intervention," The Negro Worker 2, no. 5 (May 1932): 8.

330 George Padmore, "The World Today," The Negro Worker 2, no. 8 (August 1932): 2.

331 On the international Scottsboro Campaign, see Miller, Pennybaker, and Rosenhaft, "Mother Ada Wright." 
mass mobilisation of black workers throughout the Atlantic, ${ }^{332}$ a task that especially Padmore was to put in the forefront of his activities when he took over the Hamburg Secretariat. From May 1932 onwards, the ITUCNW and its mouthpiece wholeheartedly focussed on the Scottsboro campaign, ${ }^{333}$ leaving the calling black seamen and harbour workers to support the 'Hands off China!'-campaign solely to the IsH.

332 Concrete proposals on Report of Work of Hamburg Committee, 10.6.1931, 534/3/668, 2526, RGASPI.

333 See further Weiss, Framing A Radical African Atlantic, 392-397. 